Controls, characterization and small scale chemical variations of a Karst system: A geochemical assessment of Tuscarora Creek watershed, West Virginia

\author{
Rachel V. Grand \\ West Virginia University
}

Follow this and additional works at: https://researchrepository.wvu.edu/etd

\author{
Recommended Citation \\ Grand, Rachel V., "Controls, characterization and small scale chemical variations of a Karst system: A \\ geochemical assessment of Tuscarora Creek watershed, West Virginia" (2005). Graduate Theses, \\ Dissertations, and Problem Reports. 2287. \\ https://researchrepository.wvu.edu/etd/2287
}

This Thesis is protected by copyright and/or related rights. It has been brought to you by the The Research Repository @ WVU with permission from the rights-holder(s). You are free to use this Thesis in any way that is permitted by the copyright and related rights legislation that applies to your use. For other uses you must obtain permission from the rights-holder(s) directly, unless additional rights are indicated by a Creative Commons license in the record and/ or on the work itself. This Thesis has been accepted for inclusion in WVU Graduate Theses, Dissertations, and Problem Reports collection by an authorized administrator of The Research Repository @ WVU. For more information, please contact researchrepository@mail.wvu.edu. 


\title{
Controls, Characterization and Small Scale Chemical Variations of a Karst System: A Geochemical Assessment of Tuscarora Creek Watershed, \\ West Virginia
}

\author{
Rachel V. Grand \\ Thesis submitted to the \\ College of Arts and Sciences at \\ West Virginia University \\ in partial fulfillment of the requirements \\ for the degree of \\ Master of Science in Geology \\ Dorothy J. Vesper, Ph.D., Chair \\ Joseph Donovan, Ph.D. \\ Mark D. Kozar, M.S. \\ Department of Geology and Geography \\ Morgantown, West Virginia \\ 2005
}

keywords: karst, watershed, geochemistry 


\author{
ABSTRACT \\ Controls, Characterization and Small Scale Chemical Variations of a Karst \\ System: A Geochemical Assessment of Tuscarora Creek Watershed, \\ West Virginia
}

Rachel V. Grand

Tuscarora Creek watershed is located in the Appalachian Great Valley in Berkeley County, West Virginia. Thirteen springs and seven creek locations were sampled to evaluate spatial and temporal variability in major ion geochemistry. The controlling chemical signature was carbonate dissolution; distinctions could not be made between carbonate units and little evidence was seen for the recharge from adjacent clastic rocks. The springs in the upper watershed had greater temporal variability that may be due to enhanced transmissivity associated with a creek-parallel thrust fault. Discharge data indicate the creek is supplied directly from ground water $(>50 \%)$ as well as from the springs. Geochemically, the springs and creek are similar except that the creek samples typically have a lower partial pressure of $\mathrm{CO}_{2}$ and are closer to equilibrium with calcite. The distinction may be partly attributed to degassing when ground water reaches atmospheric conditions. 


\section{Acknowledgements}

I am blessed with a strong network of people in my life who have always believed in me. Thank you to my family and friends in Missouri and beyond. You have been a source of abiding support and encouragement, in this, as well as in all of my other endeavors in life.

Thank you to my committee members for your feedback and valuable insights. I would like to thank my advisor, Dr. Dorothy Vesper, for being a mentor to me. Your professionalism, intellectual curiosity and enthusiasm have been an inspiration.

Thank you to all of the landowners of Tuscarora Creek watershed, who have allowed me access to their lovely springs, and who have always been friendly and happy to see me. 


\section{Table of contents}

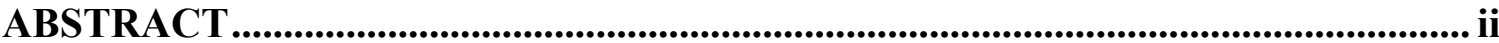

Acknowledgements ................................................................................................................ iii

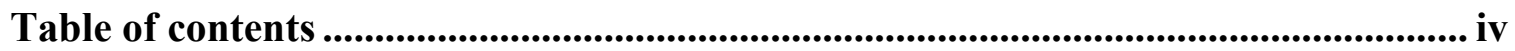

Tables .......................................................................................vi

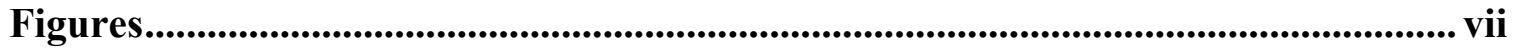

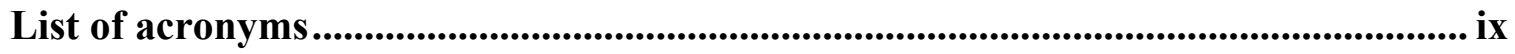

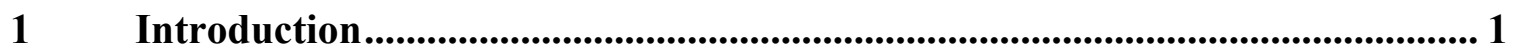

$2 \quad$ Purpose and objectives ............................................................................................. 3

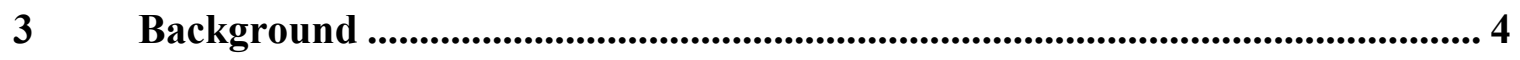

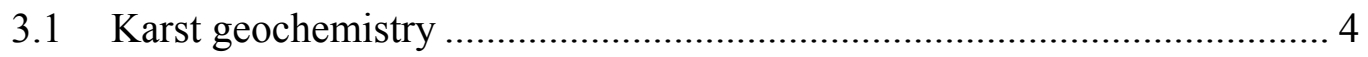

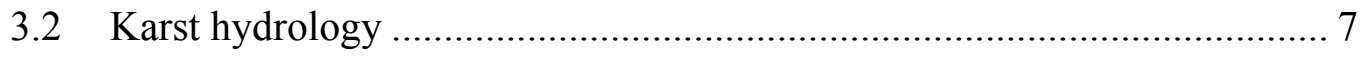

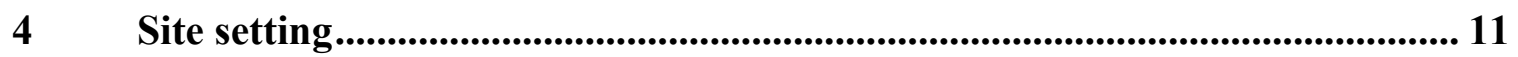

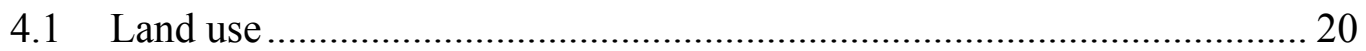

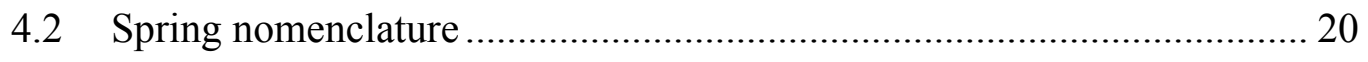

4.3 Spring descriptions.................................................................... 23

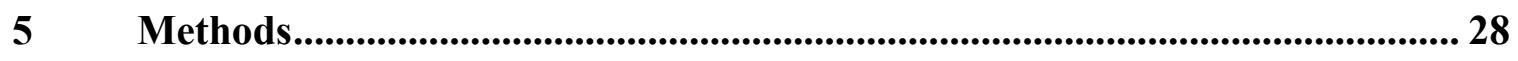

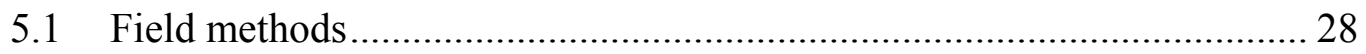

5.2 Laboratory analytical methods and detection limits ............................ 29

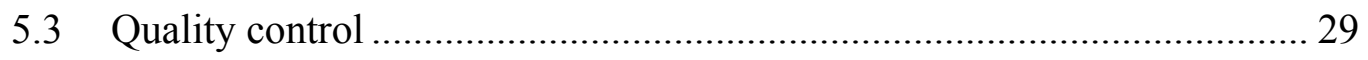

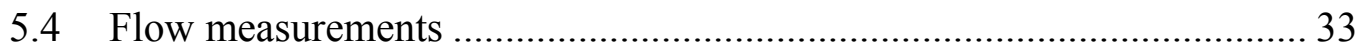

5.4.1 Quality control of flow measurements ..................................... 35

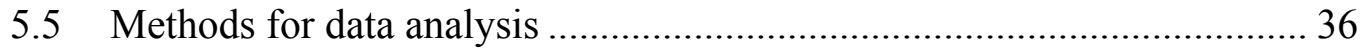

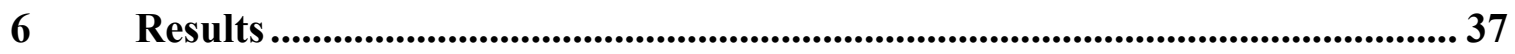




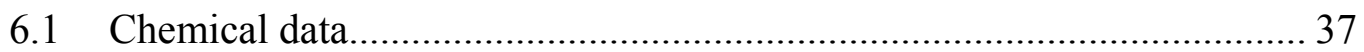

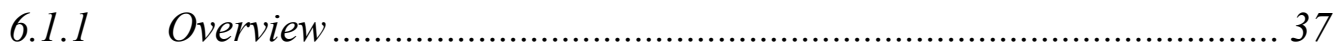

6.1.2 Major ions ....................................................................... 41

6.1.3 Derived carbonate parameters ................................................... 41

6.1.3.1 Hardness............................................................................. 41

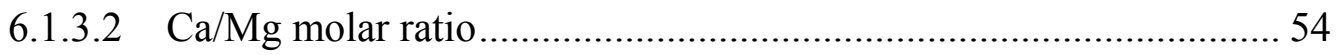

6.1.3.3 Partial pressure of $\mathrm{CO}_{2}\left(\mathrm{P}_{\mathrm{CO} 2}\right)$ and saturation index of calcite $\left(\mathrm{SI}_{\mathrm{c}}\right) .54$

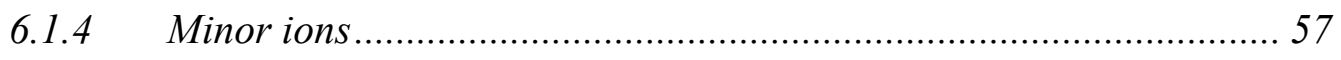

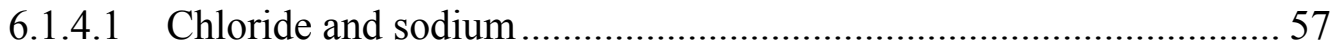

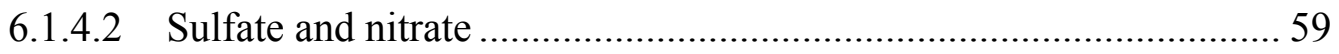

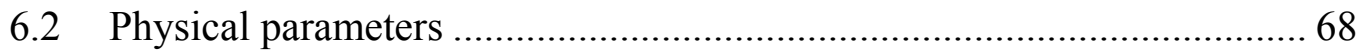

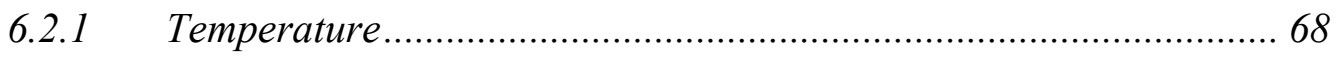

6.2.2 Flow .................................................................................. 71

6.2.3 Seepage run results ............................................................ 73

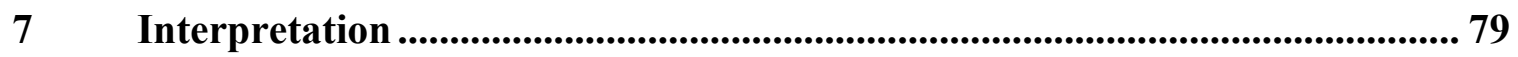

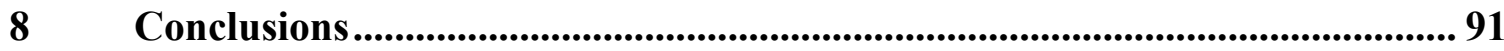

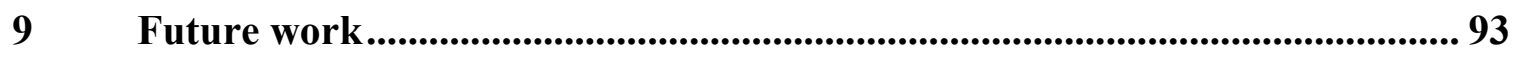

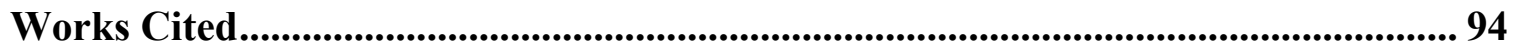

Appendix A: Chemical data ............................................................................................... 98

Appendix B: GIS metadata ......................................................................................... 108

Appendix C: Equipment and laboratory information ............................................ 112 


\section{Tables}

Table 1: Stratigraphy of Tuscarora Creek watershed (Schultz and others 1995;

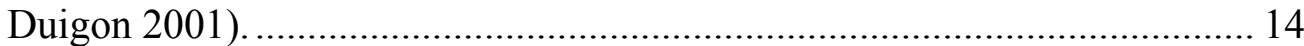

Table 2: GapLULC analysis of Tuscarora Creek watershed. ............................................. 21

Table 3: Sampling site locations............................................................................ 22

Table 4: Summary of sites included in other databases (McColloch 1986; USGS

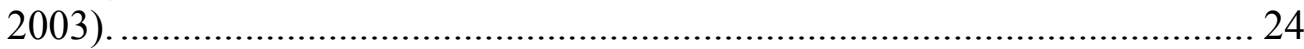

Table 5: Comparison between average measured concentrations and equipment

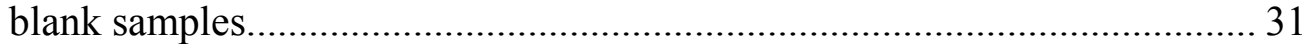

Table 6: Dates and sites sampled on Tuscarora Creek watershed. ................................... 38

Table 7: Average water chemistry of Tuscarora Creek watershed springs. ..................... 39

Table 8: Hardness COV for Tuscarora Creek watershed springs...................................... 47

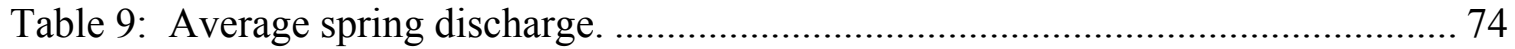

\section{Appendix Tables}

Table A-1: Field screening data................................................................................. 99

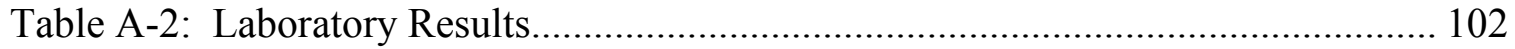

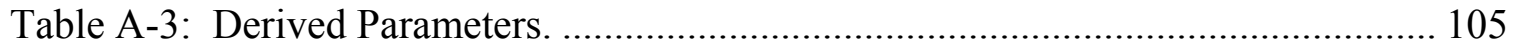

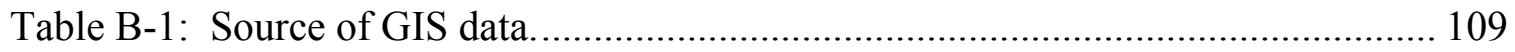

Table B-2: UTM coordinates of Tuscarora Creek watershed springs. ......................... 110

Table B-3: UTM coordinates of Tuscarora Creek gaging sites, November 2004......... 111

Table C-1: Field equipment information. ...................................................................... 113

Table C-2: Laboratory methods information. ......................................................... 114 


\section{Figures}

Figure 1: Tuscarora Creek watershed, Berkeley County, West Virginia. ........................ 2

Figure 2: Model for carbonate aquifers. Modified from Smart and Hobbs 1986............ 9

Figure 3: Contour map of Tuscarora Creek watershed............................................... 12

Figure 4: Geology of the study area. See Table 3 for key to spring names................... 15

Figure 5: Tuscarora Creek and surrounding watersheds, Berkeley County (Schultz

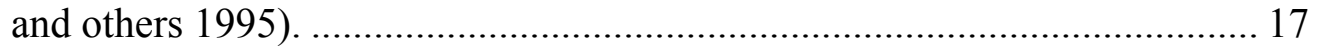

Figure 6: Elevation and schematic geology of Tuscarora Creek watershed springs. ...... 19

Figure 7: Comparison between known standards and the measured concentrations....... 32

Figure 8: Histogram, box and whisker plot of charge balance for all water samples...... 34

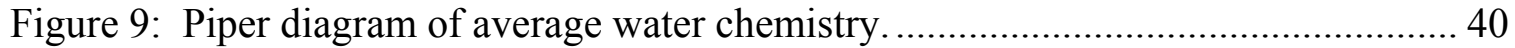

Figure 10: Box and whisker plot of $\mathrm{mg} / \mathrm{L}$ calcium of sampled springs in Tuscarora Creek watershed, $n=$ number of samples.............................................. 42

Figure 11: Temporal variability of calcium concentrations of selected Tuscarora Creek watershed springs. ...................................................................... 43

Figure 12: Spatial variability of the average calcium and magnesium concentrations of Tuscarora Creek watershed springs.

Figure 13: Box and whisker plot of $\mathrm{mg} / \mathrm{L}$ magnesium of sampled springs in Tuscarora Creek watershed, $n=$ number of samples.

Figure 14: Seasonal variation of hardness for selected Tuscarora Creek watershed

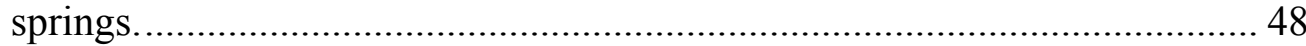

Figure 15: Temporal variability of hardness and discharge of BEL ............................. 50

Figure 16: Temporal variability of hardness and discharge of OLN . ........................... 51

Figure 17: Temporal variability of hardness and discharge of WAT........................... 52

Figure 18: Discharge versus hardness for WAT, OLN and BEL................................ 53

Figure 19: Maximum, average and minimum $\mathrm{Ca} / \mathrm{Mg}$ molar ratio for Tuscarora Creek watershed springs. 55

Figure 20: Spatial variability of enhanced $\mathrm{P}_{\mathrm{CO} 2}$ and $\mathrm{SI}_{\mathrm{c}}$ for Tuscarora Creek watershed springs............................................................................. 56

Figure 21: Ternary diagram of chloride, sulfate and nitrate mol/L........................... 58

Figure 22: Temporal variability of chloride concentrations for selected Tuscarora Creek watershed springs.

Figure 23: Temporal variability of sodium concentrations for selected Tuscarora Creek watershed springs.

Figure 24: Spatial variability of average chloride and sodium concentrations for Tuscarora Creek watershed springs.

Figure 25: Spatial variability of maximum, average and minimum nitrate concentrations in Tuscarora Creek watershed springs.

Figure 26: Temporal variability of nitrate for selected Tuscarora Creek watershed springs.

Figure 27: Spatial variability of maximum, average and minimum sulfate concentrations in Tuscarora Creek watershed springs.

Figure 28: Temporal variability of sulfate for selected Tuscarora Creek watershed springs

Figure 29: Measured temperature of Tuscarora Creek and mean air temperature as measured at Martinsburg airport (NWS 2005). 
Figure 30: Measured water temperature and mean air temperature as measured at Martinsburg airport (NWS 2005)...................................................... 70

Figure 31: Box and whisker plot of measured spring temperature, $n=$ number of samples.

Figure 32: Temporal variability in spring flow for BEL, WAT and OLN compared to average daily precipitation (NWS 2005).

Figure 33: Location of October and November 2004 gaging stations along Tuscarora Creek 76

Figure 34: Flow of Tuscarora Creek measured November 20, 2004............................ 77

Figure 35: SC of sites along Tuscarora Creek, November 20, 2004 ............................ 78

Figure 36: Molar concentrations of chloride and sodium for Tuscarora Creek watershed spring and stream samples.

Figure 37: Estimated contribution to flow in Tuscarora Creek from springs and direct groundwater discharge. Bold line = best fit to data using exponential equation.

Figure 38: $\log \mathrm{P}_{\mathrm{CO} 2}$ versus $\mathrm{SI}_{\mathrm{c}}$ for Tuscarora Creek watershed water samples, modified from White 1997.

Figure 39: Comparison of average Tuscarora Creek watershed $\log \mathrm{P}_{\mathrm{CO} 2}$ and $\mathrm{SI}_{\mathrm{c}}$ values to other Appalachian sites. 


\section{List of acronyms}

\section{Location names}

$\begin{array}{ll}\text { BEL } & \text { Bella Vista Farm } \\ \text { BRK } & \text { Burkhart Spring } \\ \text { DBR } & \text { Mike Burkhart Farm } \\ \text { DOD } & \text { Dodson Farm } \\ \text { JSF } & \text { Jim Smith Farm } \\ \text { KMR } & \text { Kilmer Spring } \\ \text { NWM } & \text { Newman Farm } \\ \text { OLN } & \text { Olean Spring } \\ \text { PHD } & \text { Paul Hunt Farm Downgradient Spring } \\ \text { PHS } & \text { Poor House Farm } \\ \text { PHU } & \text { Paul Hunt Farm Upgradient Spring } \\ \text { TBE } & \text { Tuscarora Creek above BEL } \\ \text { TFS } & \text { Roach Farm Spring } \\ \text { THT } & \text { Tuscarora Creek above PHU and PHD } \\ \text { TKS } & \text { Tuscarora Creek above KMR } \\ \text { TNM } & \text { Tuscarora Creek above NWM } \\ \text { TOL } & \text { Tuscarora Creek above OLN } \\ \text { TPH } & \text { Tuscarora Creek above PHS } \\ \text { TWA } & \text { Tuscarora Creek above WAT } \\ \text { WAT } & \text { Water Street Spring }\end{array}$

\section{Other acronyms}

$\begin{array}{ll}\text { BDL } & \text { Below method detection limit } \\ \text { COV } & \text { Coefficient of variation } \\ \text { GapLULC } & \text { Gap Land Use Land Cover } \\ \text { IC } & \text { Ion chromatograph } \\ \text { ICP-OES } & \text { Inductively coupled plasma optical emission spectrometer } \\ \text { MDL } & \text { Method detection limit } \\ \text { NM } & \text { Not measured } \\ \text { NRCCE } & \text { National Research Center for Coal and Energy } \\ \mathrm{P}_{\mathrm{CO} 2} & \text { Partial pressure of carbon dioxide } \\ \mathrm{SC} & \text { Specific conductance } \\ \mathrm{SI}_{\mathrm{x}} & \text { Saturation index of mineral x } \\ \mathrm{TDS} & \text { Total dissolved solids }\end{array}$




\section{Introduction}

Tuscarora Creek watershed is located in the Eastern Panhandle of West Virginia (Figure 1), in a region of folded and faulted sedimentary rocks. The watershed is underlain largely by carbonate rocks (Schultz and others 1995). The upper watershed is primarily rural, but becomes increasingly developed downstream. The region as a whole is experiencing substantial growth in housing and development. The population of Berkeley County has increased 28\% between 1990 and 2000 (U.S. Census Bureau, 2005).

Spatial variability of the water chemistry is due in part to groundwater interaction with carbonate rocks. The concentrations of dissolved cations and anions can quantify the water-rock interaction. Calculations such as $\mathrm{SI}_{\mathrm{C}}$ and $\mathrm{P}_{\mathrm{CO} 2}$ can help to refine this description. Faults or lineaments may also control spring discharge, both spatially and by volume. Tuscarora Creek itself may also be in part structurally controlled. This study area has abundant springs located on different geologic units. Tuscarora Creek flows both perpendicular and parallel to the strike of the bedrock. There are few, if any, tributaries to Tuscarora Creek.

This is an ideal setting for investigating the interactions of groundwater and surface water, as well as examining how different lithologies affect water chemistry. The transition from rural to urban portions of the watershed should be evident in the water chemistry of the springs selected for sampling. This study will help to characterize Tuscarora Creek watershed as the region changes from chiefly farming to more extensive urbanization. 


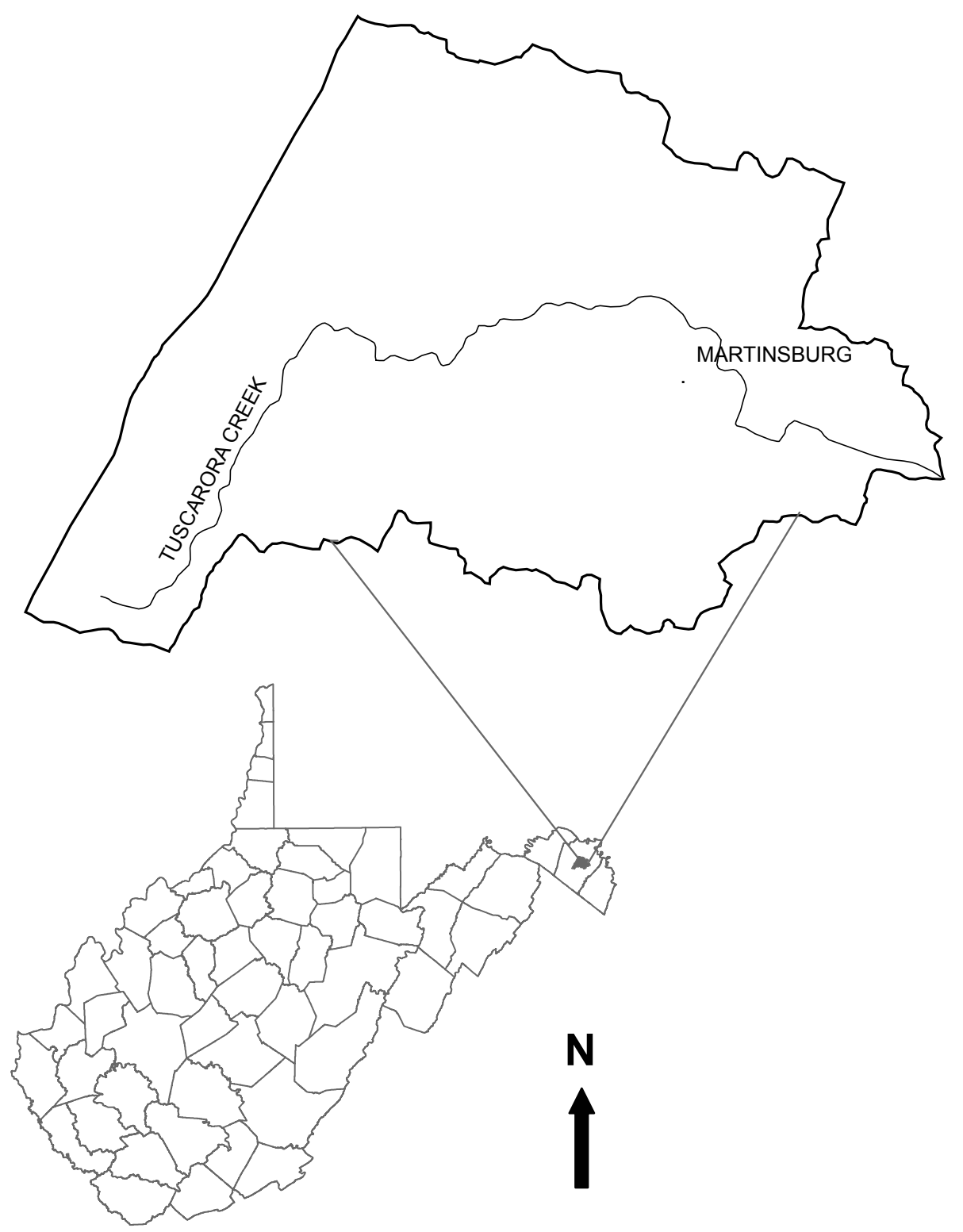

Figure 1: Tuscarora Creek watershed, Berkeley County, West Virginia. 


\section{Purpose and objectives}

The purpose of this project is to identify some of the controls on flow and chemical evolution in a karst system. The effects of geology and land use on the water chemistry of this watershed are currently unknown. The interaction between groundwater and surface water will also be investigated.

There are several questions posed for this research project:

1) To what extent does groundwater contribute flow to Tuscarora Creek?

2) How does the major ion chemistry of the springs and Tuscarora Creek itself vary spatially and temporally?

3) How is this chemical variability controlled by land use in the watershed?

4) How does the geology of the region control the springs and Tuscarora Creek?

5) How does a small-scale study fit larger models of karst systems?

The data set used to answer these questions consists of multiple chemical parameters collected from closely spaced sites through time. The temporal variability in composition of these sites reveals the variations of flow paths and mixing of waters (Shuster and White 1971; Martin and Gordon 2000). 


\section{Background}

There has been much work done in attempting to describe models for karst aquifers. These aquifers pose a unique challenge because many of the traditional approaches to aquifer characterization do not work, or do not provide a complete picture of karst terranes. The enhanced solubility of carbonate rocks, and how this relates to recharge, storage and flow within the aquifer, creates a greater level of complexity when trying to understand a karst system (Smart and Hobbs 1986).

Water chemistry has been used to identify the flow paths and other physical characteristics of karst aquifers. The combination of geochemistry and hydrology can helped to describe these systems. Much of this work has used springs as sampling points. Shuster and White (1971) examined a Central Appalachian karst aquifer and defined springs as being chiefly diffuse or conduit flow based on chemical parameters. This terminology can be used when acknowledging that many springs fall somewhere on the continuum (Quinlan 1989). White (1999) has emphasized that this is a theoretical model, with extreme end members, but suggests that, especially when considering water supplies, it is valuable to differentiate systems fed primarily by fracture from those supplied by conduits.

\subsection{Karst geochemistry}

The primary solubility of carbonate rocks is greater than non-carbonate rocks under normal surface conditions. The basic reaction of limestone with water is enhanced by the presence of dissolved $\mathrm{CO}_{2}$ : 


$$
\mathrm{CaCO}_{3}+\mathrm{H}_{2} \mathrm{O}+\mathrm{CO}_{2}(\mathrm{~g}) \leftrightarrow \mathrm{Ca}^{2+}+2 \mathrm{HCO}_{3}^{-}
$$

$\mathrm{Ca}^{2+}$ and $\mathrm{HCO}_{3}^{-}$are the dominant dissolved species produced by limestone dissolution, and are dependent on the partial pressure of $\mathrm{CO}_{2}\left(\mathrm{P}_{\mathrm{CO} 2}\right)$ of waters (Drever 1997; Langmuir 1997). At low temperatures and pressures, the partial pressure of a gas is equal to its activity (Langmuir 1997).

There is a non-linear positive correlation between increased $\mathrm{P}_{\mathrm{CO} 2}$ and dissolution rates in karst systems, with $\mathrm{CO}_{2}$ often above atmospheric pressures (Brahana and others 1988; White 1988). Rainwater at equilibrium with the atmosphere has a $\mathrm{P}_{\mathrm{CO} 2}$ of $10^{-3.5}$ atmospheres (atm) while aqueous soil zones often have $10^{-2.5}$ to $10^{-1.5}$ atm (Drever 1997). $\mathrm{P}_{\mathrm{CO} 2}$ is produced in the soil zone by biological activity (Drever 1997). Seasonal variation in $\mathrm{P}_{\mathrm{CO} 2}$ is common, but not universal (Atkinson 1977). Uniformly elevated $\mathrm{P}_{\mathrm{CO} 2}$ levels in the vadose zone can occur, usually in an open system, in which the reactions occurs until all phases equilibrate (Atkinson 1977). There is an inverse relationship between $\mathrm{pH}$ and $\mathrm{P}_{\mathrm{CO} 2}$ (Langmuir 1997). Dissolution of carbonate rocks is enhanced by a decrease in $\mathrm{pH}$ (Langmuir 1997).

The saturation index of calcite $\left(\mathrm{SI}_{\mathrm{c}}\right)$ may be an indicator of relative residence time, and $\mathrm{P}_{\mathrm{CO} 2}$ can help to identify the paths that recharge entered the system (Drake and Harmon 1973). $\mathrm{P}_{\mathrm{CO} 2}$ and $\mathrm{SI}_{\mathrm{c}}$ have an inverse relationship, with the precipitation of calcite facilitated by the degassing of $\mathrm{CO}_{2}$ (White 1988; White 1997).

Specific conductance (SC) can indicate relative residence time of waters (Jacobson and Langmuir 1970). The molar ratio of $\mathrm{Ca}^{2+} / \mathrm{Mg}^{2+}$ can indicate whether groundwater flow was through limestone or dolomite (Jacobson and Langmuir 1970). 
Water with a ratio of one flowed through dolomite, and ratios higher than one indicate predominantly limestone interaction (White 1988).

The coefficient of variation of hardness (COV) has been used to characterize end member springs as conduit or diffuse (Shuster and White 1971). The COV is an expression of the variation of a parameter (Davis 2002). The numerical values for the $\mathrm{COV}$ of hardness have been used to differentiate springs as conduit or diffuse (Shuster and White 1971). Springs characterized as conduit-flow are generally lower in hardness and have greater temperature fluctuation than those characterized as diffuse flow (Shuster and White 1971). The COV of hardness was found to be less than $5 \%$ for diffuse-flow springs, while the variation was much greater for conduit-flow springs (Shuster and White 1971).

Jacobson and Langmuir (1973) have pointed out that there is a flux in temperature that can be attributed to seasonal variation, not just spring type. Chemical and physical characteristics of springs are not just a factor of flow paths, but are also influenced by recharge type and distance of flow path (Scanlon and Thrailkill 1987). Drake and Harmon (1973) described a stylized carbonate terrane, based on data from two Appalachian carbonate valleys. They identified six different types of waters found in this idealized setting, such as allogenic recharge. Using linear discriminant function analysis, Drake and Harmon (1973) were able to accurately place approximately three-fourths of their samples in the correct geographic setting. This analysis was based on the chemical characteristics and the water types, which were distinguished from each other at the 0.005 confidence level. The watersheds were similar to Tuscarora Creek watershed, and the 
conclusions from that study may apply to the data collected for this project (Drake and Harmon 1973)

Martin and Gordon (2000) call attention to the need for in-depth, small-scale studies of karst watersheds. Such studies can help to describe flow paths, short-term heterogeneity and reactions between bedrock and water. Tuscarora Creek watershed affords a compact glimpse into an Appalachian karst system, with closely spaced springs, and opportunities for surface water monitoring as well.

Previous work examining watersheds have found that even small watersheds can have variable chemical characteristics that can be attributed to differences in recharge, soil characteristics and elevation (O' Driscoll and others 2005). Small-scale watershed studies can reveal sites that are particularly susceptible to contamination (Mahler 1991; Salg 1997). The watershed scale is effective for evaluating regional models, and refining these models (Desmarais 1995).

Springs provide a unique snapshot of karst systems, providing information on flow paths and other aquifer characteristics. Springs are a "composite of everything that has happened upstream... and are the appropriate gaging points, sampling points and monitoring points for karst aquifers" (White, 1999).

\subsection{Karst hydrology}

Karst aquifers typically have both laminar and turbulent flow. Diffuse-flow springs obey Darcy's law, with limited solutionally-widened flow paths, while conduitflow springs have localized, often turbulent flow through large open conduits (White 1969; Shuster and White 1971; White 1993). 
White describes a triple permeability model comprised of matrix, fracture and conduit permeability (1999). These three are probably not distinct end members and will vary through time and space, as, for example, fractures are solutionally enlarged to conduits (White 1999). The flow of water through matrix, channels, and fractures is also described as a triple-porosity aquifer (Worthington and others 2000). In a study of central Kentucky karst, the majority of storage was found to be in the rock matrix, while permeability was almost completely due to channels (Worthington and others 2000).

The primary permeability of unweathered Paleozoic limestones, such as the carbonate rocks in Berkeley County, is generally low, with porosity ranging from 0.1 to $10 \%$ and hydraulic conductivity from $10^{-4}$ to 1 meter/day (Brahana and others 1988). There are a variety of faults and geologic structures in the study area that could enhance flow through the aquifer (Page 1963; Zewe and Rauch 1991). Flow can also be enhanced by bedding planes and lineaments (Schultz and others 1995).

The inflows and outflows for a carbonate aquifer (Smart and Hobbs 1986) can be illustrated using a simple model (Figure 2). The recharge includes dispersed sources such as precipitation and fracture and intergranular flow, to concentrated flow such as losing streams and allogenic recharge (Smart and Hobbs 1986; White 1999). Storage can be in a variety of locations within a karst system. Within the unsaturated zone, the soil and epikarst are important (Smart and Hobbs 1986; White 1993; White 1999). In the saturated zone, fractures, intergranular storage, perennial storage, and dynamic storage are important reservoirs for water (Smart and Hobbs 1986). Dynamic storage is the volume of water between the water table and base level (as represented by the level at 


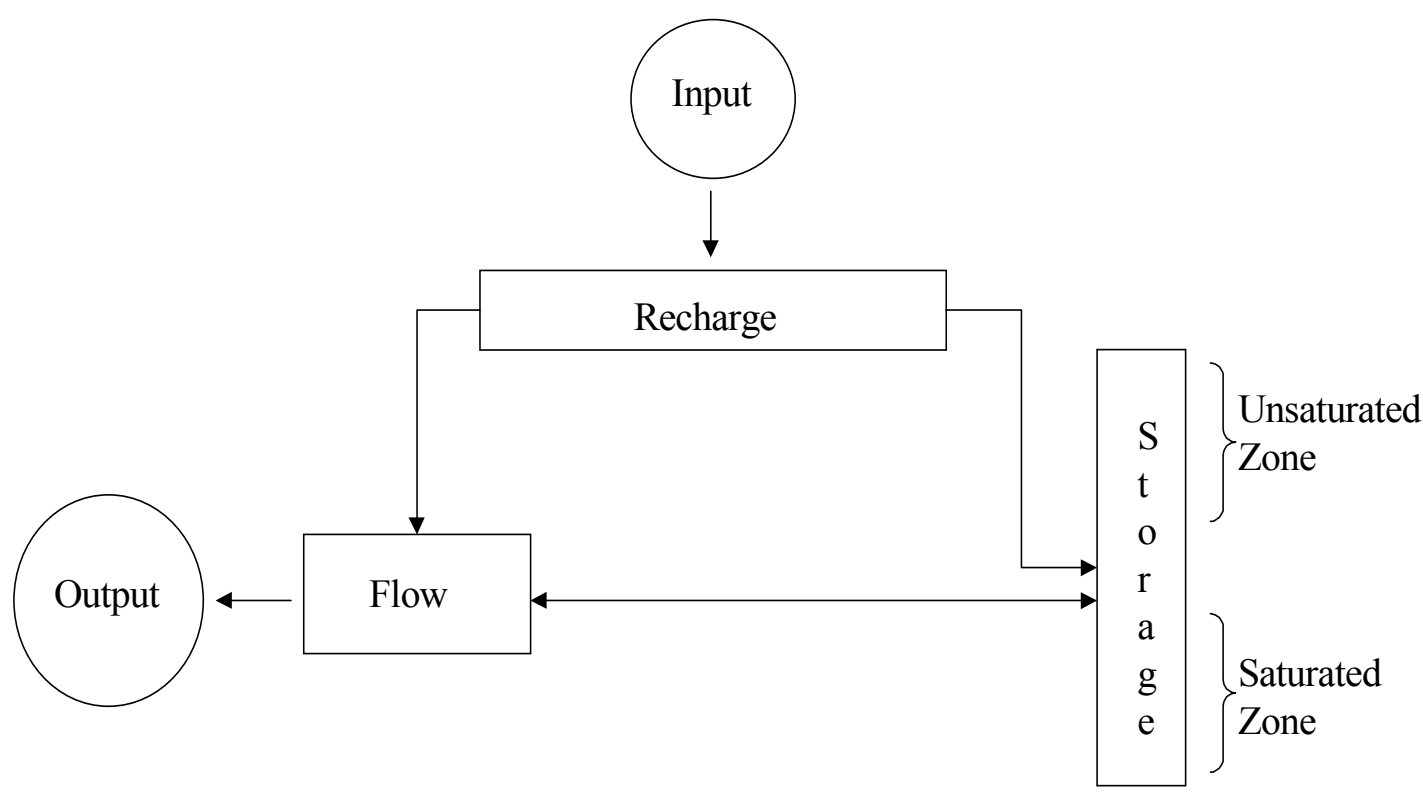

Figure 2: Model for carbonate aquifers. Modified from Smart and Hobbs 1986. 
which conduit-flow springs discharge), and is comprised of small-scale solutional voids (White 1993). For the Smart and Hobbs model, flow can be characterized as conduit or diffuse, each end-members of the spectrum, with actual carbonate aquifers generally having characteristics of both (Smart and Hobbs 1986; White 1993). The output is generally through springs (discrete source) or discharge to surface water bodies, such as rivers (dispersed source). Once again, most karst systems lie between the end members. The other primary source of output is from evapotranspiration (White 1993). 


\section{Site setting}

Tuscarora Creek is part of the Potomac River Basin watershed. Tuscarora Creek watershed is located within the Valley and Ridge Province, with the majority of the limestone units Cambrian or Ordovician in age (Hobba 1976). This physiographic province extends from Pennsylvania to Alabama.

The karst systems in the Eastern Panhandle of West Virginia are fed mainly by fracture flow (Jones 1997). Primary porosity is limited due to intergranular cementation (Schultz and others 1995). The lack of conduit flow is due to an abundant fracture system, low relief and gradient, and minimal allogenic recharge area (Jones 1991). North Mountain, formed by the Tuscarora Sandstone, provides a local source of allogenic recharge, which is surface recharge from non-carbonate portions of the drainage basin recharge area (White 2002).

The difference in relief between North Mountain and the carbonate rocks of the valley provides a hydraulic gradient, and thus a possible driving force for water in the upper watershed (Figure 3). There is a smaller gradient difference in the lower reaches of Tuscarora Creek watershed, based on topography.

The dominant structure in western Berkeley County is the Massanutten Synclinorium, with folded and faulted bedrock trending N 20 E (Zewe and Rauch 1991; Schultz and others 1995). The rocks comprising a synclinal aquifer throughout the western portion of Berkeley County are carbonate and shale (McCoy and others 2005). 


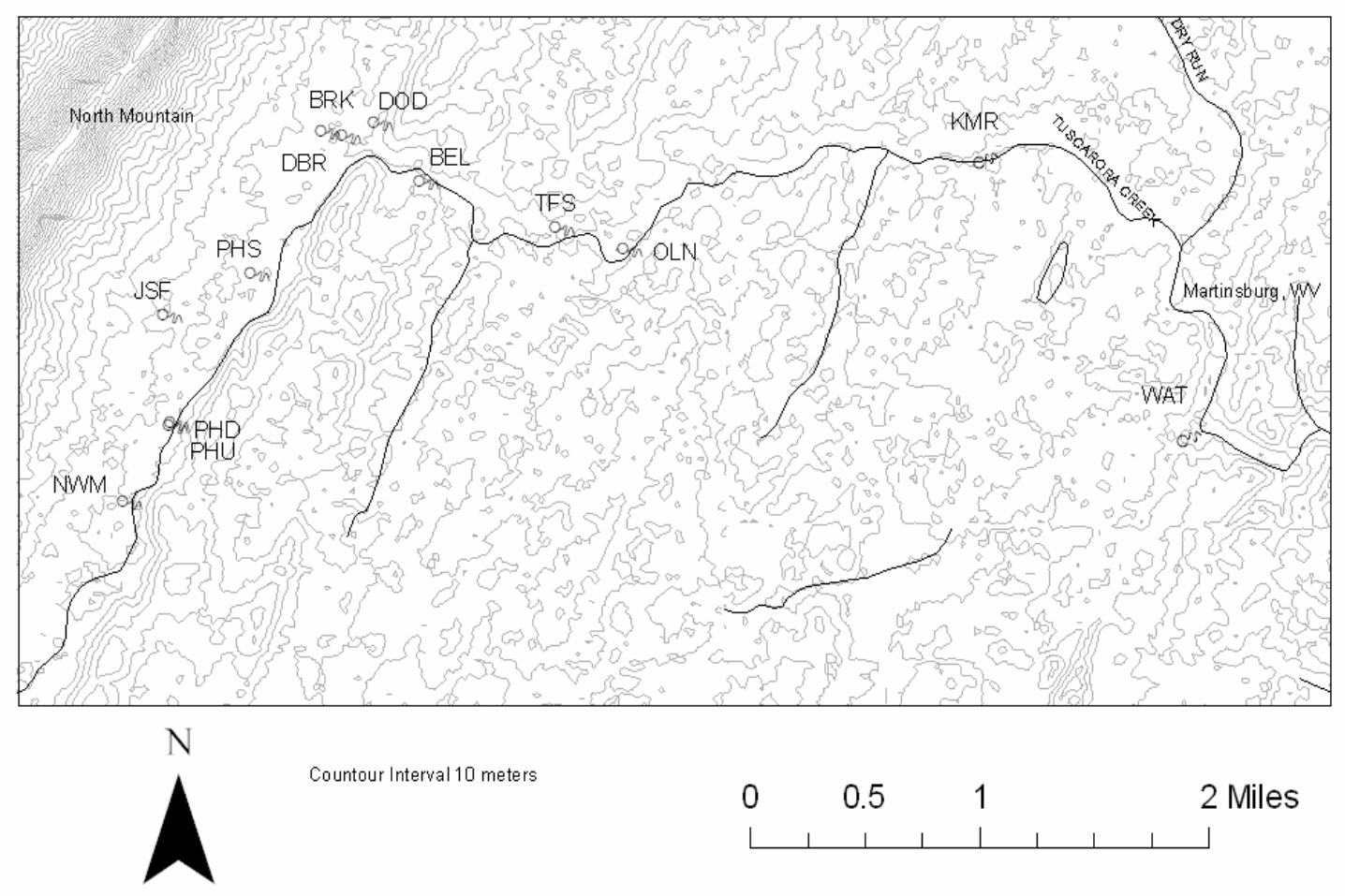

Figure 3: Contour map of Tuscarora Creek watershed. 
The portions of Berkeley County underlain by carbonates are more heavily faulted than the non-carbonate areas (Schultz and others 1995). Cementing of fault zones with calcite may force water to the surface, increase solution on up gradient sides of faults, and act as an obstacle to groundwater flow (Jones 1991). The rocks located in the study area are primarily limestone, although many of the units have associated dolomite beds (Schultz and others 1995; Duigon 2001). The Martinsburg is primarily shale and the Elbrook has shale beds interspersed with limestone (Table 1).

The geology is shown with the surface watershed boundary of Tuscarora Creek as an extent of coverage (Figure 4). For a groundwater study, this may be misleading, as the surface and groundwater divides are probably not coincident. Without further work, such as dye tracing, the actual groundwater divides are unknown.

There are several faults within Tuscarora Creek watershed (Figure 4). The upper portion of Tuscarora Creek trends along a thrust fault (Figure 4). Using GIS, five of the thirteen springs mapped for the project were found to be within 0.2 kilometers of a mapped fault. Cross-strike fractures may provide areas of higher transmissivity (McCoy and others 2005). Fractures may determine spring locations as well as the path of Tuscarora Creek (McCoy and others 2005).

The sources of recharge in the study area are primarily precipitation and allogenic recharge from North Mountain. This allogenic recharge enters the limestone system that comprises the valley bottom, and the upper reaches of Tuscarora Creek watershed. Other groundwater boundaries or sources of recharge for this watershed are not known at this point. 
Table 1: Stratigraphy of Tuscarora Creek watershed (Schultz and others 1995; Duigon 2001).

\begin{tabular}{|c|c|c|c|c|}
\hline System & Group & Formation (Map ID) & Rock Type & $\begin{array}{l}\text { Importance to } \\
\text { Study }\end{array}$ \\
\hline Silurian & & Tuscarora (St) & sandstone & $\begin{array}{l}\text { Forms ridge of } \\
\text { North Mountain }\end{array}$ \\
\hline \multirow{5}{*}{ Ordovician } & \multirow{5}{*}{ Beekmantown } & Martinsburg (Om) & $\begin{array}{l}\text { Soft, thin-bedded } \\
\text { shale, shaley } \\
\text { limestone }\end{array}$ & $\begin{array}{l}\text { Base of North } \\
\text { Mountain }\end{array}$ \\
\hline & & $\begin{array}{c}\text { Trenton (Otbr) } \\
\text { Black River (Omc) } \\
\text { New Market (Osp) }\end{array}$ & $\begin{array}{l}\text { limestone } \\
\text { limestone } \\
\text { limestone }\end{array}$ & \\
\hline & & Pinesburg Station (Obps) & $\begin{array}{l}\text { dolomite, } \\
\text { abundant chert }\end{array}$ & $\begin{array}{c}1 \text { spring located on } \\
\text { unit }\end{array}$ \\
\hline & & Rockdale Run(Obrr) & $\begin{array}{l}\text { limestone and } \\
\text { dolomite }\end{array}$ & $\begin{array}{l}7 \text { springs located } \\
\text { on unit }\end{array}$ \\
\hline & & Stonehenge (Obs) & $\begin{array}{l}\text { ribbony, fine } \\
\text { grained } \\
\text { limestone } \\
\end{array}$ & \\
\hline \multirow[t]{2}{*}{ Cambrian } & & Conococheague (Cc) & $\begin{array}{l}\text { Ribbony, } \\
\text { interbedded } \\
\text { limestone, } \\
\text { dolostone and } \\
\text { sandstone }\end{array}$ & $\begin{array}{l}1 \text { spring located on } \\
\text { unit }\end{array}$ \\
\hline & & Elbrook (Ce) & $\begin{array}{l}\text { calcareous shale, } \\
\text { limestone, } \\
\text { dolomite }\end{array}$ & $\begin{array}{l}4 \text { springs located } \\
\text { on unit }\end{array}$ \\
\hline
\end{tabular}




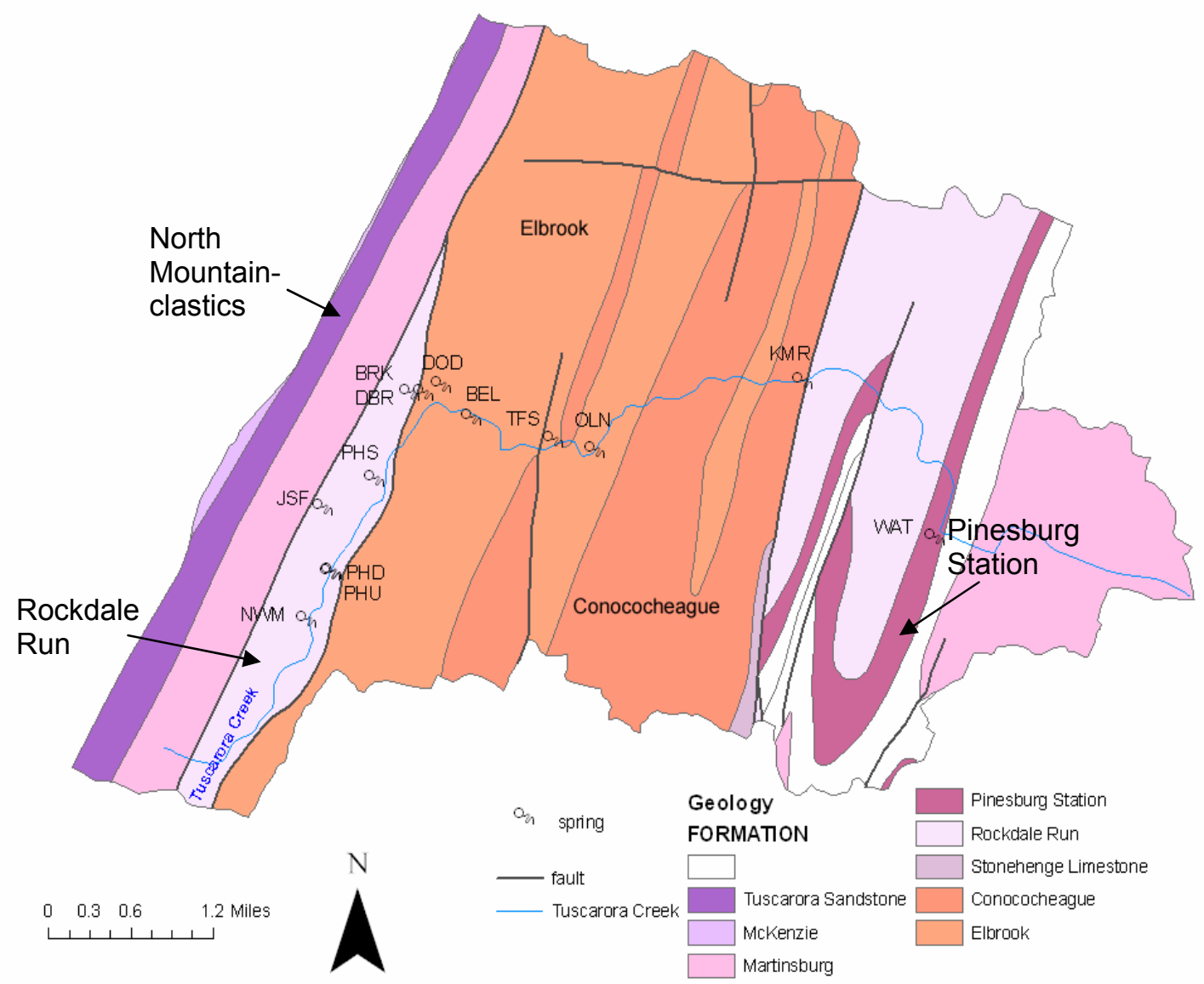

Figure 4: Geology of the study area. See Table 3 for key to spring names. 
Based on previous work, some reaches of Tuscarora Creek are losing (Schultz and others 1995). Groundwater feeds Tuscarora Creek, contributing an estimated $86.5 \%$ of total flow, based on hydrograph separation (Schultz and others 1995). The hydrologic conditions and interpretations of contribution of springs to flow of stream are unclear (Schultz and others 1995). Tuscarora Creek may also capture flow from the nearby watersheds (Figure 5) of Middle Creek and Evans Run (Schultz and others 1995).

Average transmissivity has been estimated for two portions of Tuscarora Creek watershed (Schultz and others 1995). These calculations used base-flow stream measurements and groundwater levels in an observation well (Schultz and others 1995). The assumptions for the transmissivity values are that the aquifer is homogenous and isotropic, that it is bound on two sides by streams that fully intersect the water table, and that recharge is constant spatially and temporally (Schultz and others 1995). The upper watershed (Figure 5 transect E-E') was estimated to have a transmissivity of between 442 and $479 \mathrm{~m}^{2} / \mathrm{d}$, and the lower watershed (Figure 5 transect D-D') was estimated at between 189 and $244 \mathrm{~m}^{2} / \mathrm{d}$ (Schultz and others 1995). The upper watershed estimate was parallel to strike, and the lower was perpendicular to strike (Figure 5). The stream in the upper watershed is located near a mapped thrust fault and this influence may account for the higher transmissivity values (Figure 4).

The general trend for groundwater movement in the study area (Figure 5) is towards the axis of the Massanutten Synclinorium, in a southeast direction (Schultz and others 1995). The trellis pattern of the surface drainage also follows this general trend, except in the upper portion of Tuscarora Creek, where stream flow is parallel to strike (Figure 5). The trend of the springs in the upper portion of Tuscarora Creek watershed 


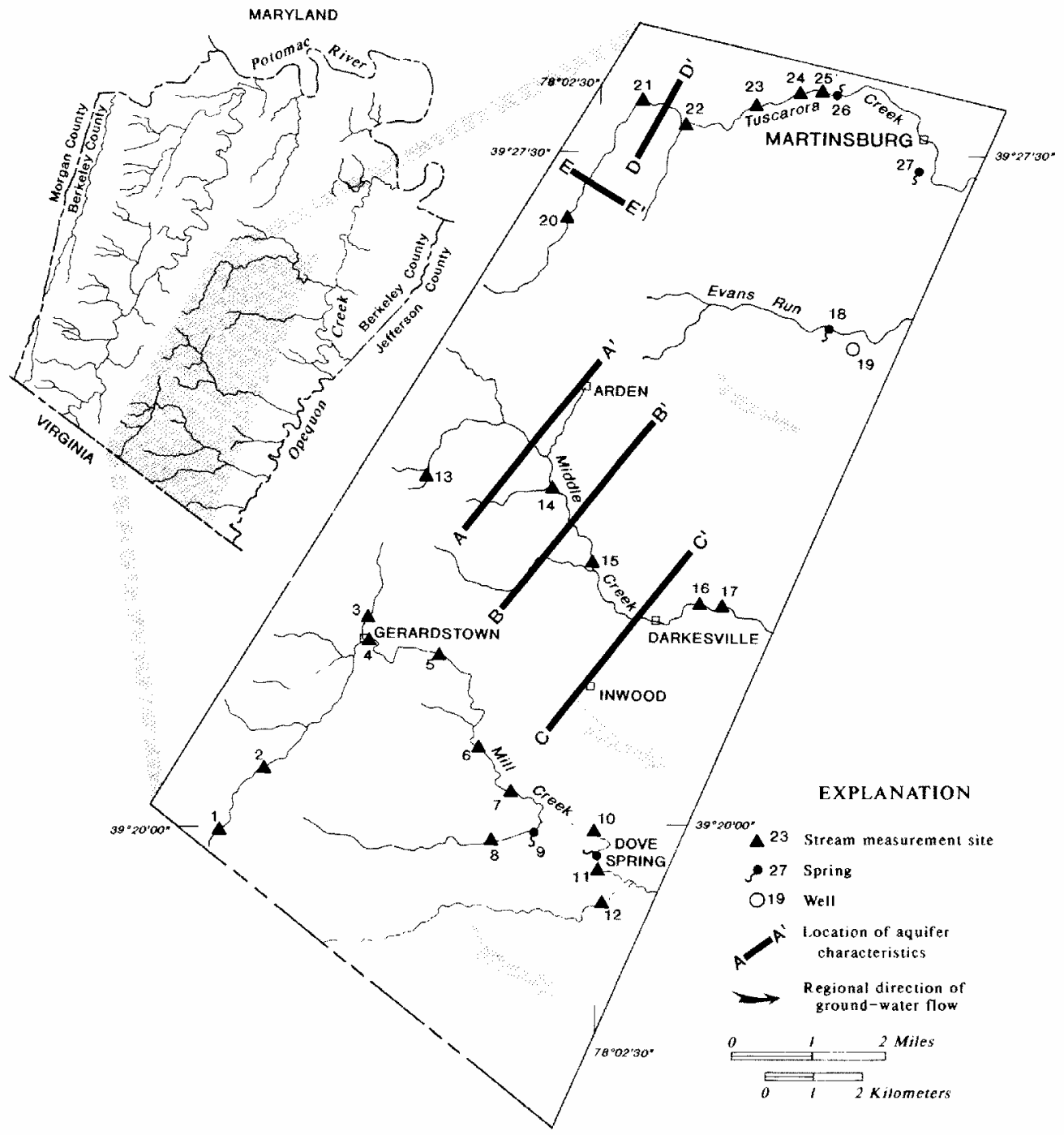

Figure 5: Tuscarora Creek and surrounding watersheds, Berkeley County (Schultz and others 1995). 
are generally parallel to strike, and the lower springs are perpendicular to strike (Figure $6)$.

For the graphs in this thesis, the distance between the springs is the straight-line distance between each site (Figure 6). The distance begins at zero meters for the most upstream location (Figure 6). The sections of the creek that are parallel and perpendicular to strike are also indicated (Figure 6). The approximate boundaries of the different rock units are indicated with dashed vertical lines (Figure 6). 


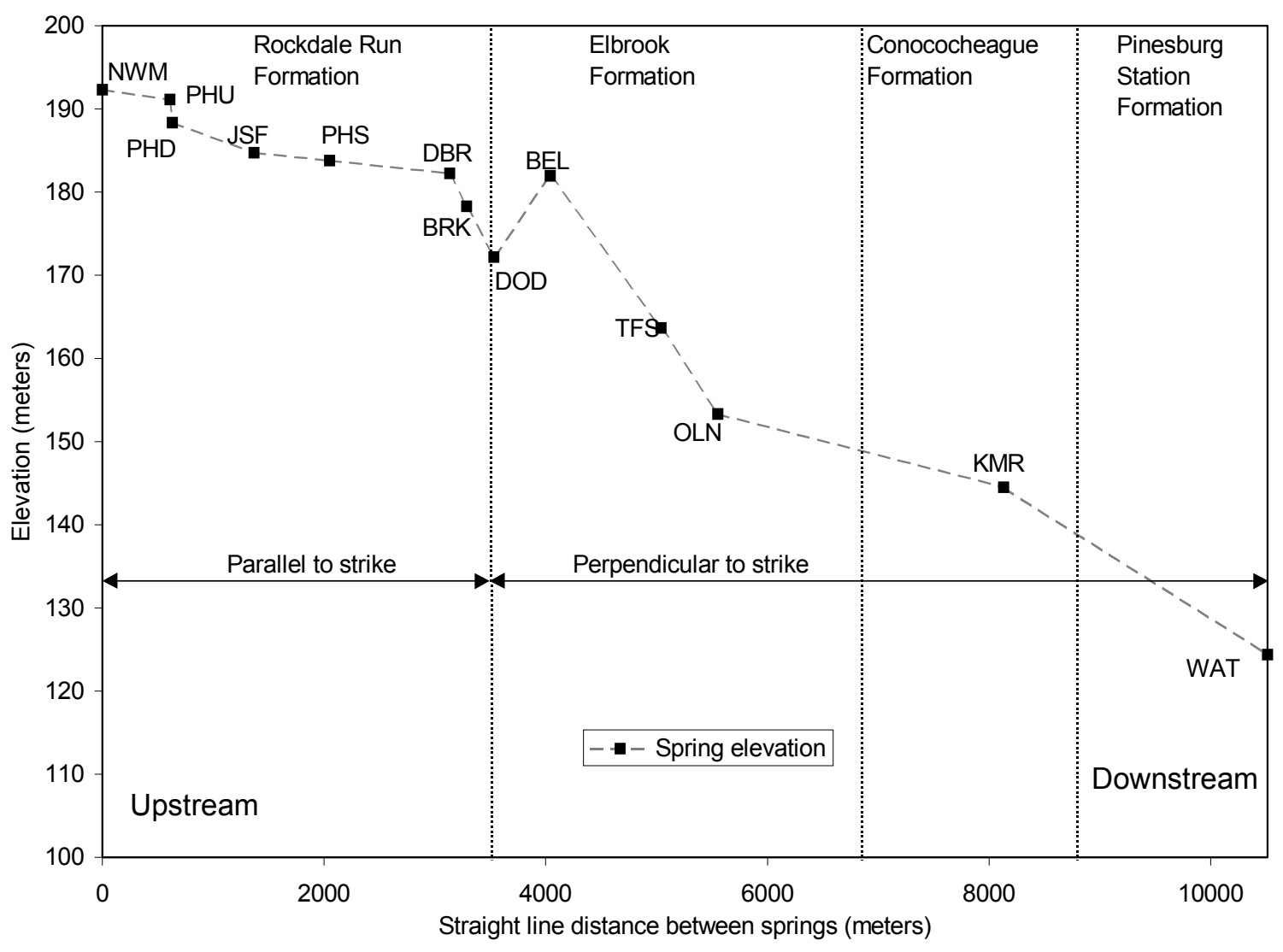

Figure 6: Elevation and schematic geology of Tuscarora Creek watershed springs. 


\subsection{Land use}

Landscape characteristics can affect the water chemistry of a watershed. Urban watersheds have more impervious areas than rural watersheds, resulting in more rapid runoff and possible subsequent contamination. Tuscarora Creek has both urban (lower watershed) and rural (upper watershed) reaches. Using a gap land use/land cover grid (GapLULC), derived from satellite imagery collected in 1993 and 1994, the dominant land covers for Tuscarora Creek watershed were determined (Table 2). As of 1993-4, three-fourths of the watershed was non-urban (Table 2).

Two springs (KMR and WAT) are located within 100 meters of the areas classified as urban. Proximity of springs to roads is also of interest for the interpretation of the geochemical data. With the exception of PHS, NWM and DOD, all of the springs are located within 100 meters of a road.

\subsection{Spring nomenclature}

Thirteen springs along Tuscarora Creek watershed have been sampled for this project. Tuscarora Creek was periodically sampled at seven different locations. These sites were distributed along the stream, and were chosen for the proximity to the springs. Creek sampling sites were selected for proximity to the springs. These sites were sampled up gradient of the spring confluence with the stream, in order to characterize the upstream chemistry (Table 3).

Three letter codes were assigned to each of these sites, and these codes will be used for identification (Table 3). The number after the spring code refers to the sampling round. 
Table 2: GapLULC analysis of Tuscarora Creek watershed.

\begin{tabular}{cccc}
\hline Reclassification & Description & meters ${ }^{2}$ & $\%$ of total \\
\hline non-urban & Pasture/grassland & $24,420,600$ & 35.6 \\
non-urban & Oak dominant forest & $18,397,800$ & 26.8 \\
Urban & Light intensity urban & $11,069,100$ & 16.2 \\
non-urban & Row crop agriculture & $4,190,400$ & 6.11 \\
non-urban & Diverse/mesophytic hardwood & $3,353,400$ & 4.89 \\
Urban & forest & $2,733,300$ & 3.99 \\
Urban & Populated areas & $1,581,300$ & 2.31 \\
Urban & Moderate intensity urban & 968,400 & 1.41 \\
non-urban & Intensive urban & 729,900 & 1.06 \\
Urban & Hardwood/conifer forest & 249,300 & 0.36 \\
non-urban & Roads & 170,100 & 0.25 \\
non-urban & Forested wetland & 130,500 & 0.19 \\
Urban & Shrubland & 126,900 & 0.19 \\
non-urban & Barren land - mining, & 118,800 & 0.17 \\
non-urban & construction & 111,600 & 0.16 \\
non-urban & Surface water & 81,900 & 0.12 \\
Urban & Surface water & 71,100 & 0.10 \\
Urban & Shrub wetland & 53,100 & 0.08 \\
Total & Power lines & $68,557,500$ & \\
urban total & Herbaceous wetland & $16,799,400$ & 24.5 \\
non-urban total & & $51,758,100$ & \\
\hline & & & \\
\hline
\end{tabular}


Table 3: Sampling site locations.

\begin{tabular}{|c|c|c|c|c|c|c|}
\hline Site Name & $\begin{array}{l}\text { Project } \\
\text { Code }\end{array}$ & Ownership & $\begin{array}{c}\text { First } \\
\text { Chemical } \\
\text { Sampling } \\
\text { Date }\end{array}$ & $\begin{array}{c}\text { \# of } \\
\text { chemical } \\
\text { samples }\end{array}$ & $\begin{array}{l}\text { Site Bedrock } \\
\text { Geologic Unit }\end{array}$ & $\begin{array}{l}\text { Elevation } \\
\quad(\mathrm{m})\end{array}$ \\
\hline Newman Farm & NWM & private & Jul-04 & 4 & Rockdale Run & 192 \\
\hline $\begin{array}{c}\text { Tuscarora Creek } \\
\text { above NWM }\end{array}$ & TNM & private & Sep-04 & 1 & Rockdale Run & 191 \\
\hline $\begin{array}{l}\text { Paul Hunt Farm } \\
\text { Upgradient Spring }\end{array}$ & PHU & private & Sep-04 & 3 & Rockdale Run & 191 \\
\hline $\begin{array}{l}\text { Paul Hunt Farm } \\
\text { Downgradient } \\
\text { Spring }\end{array}$ & PHD & private & Sep-04 & 3 & Rockdale Run & 188 \\
\hline $\begin{array}{c}\text { above PHU and } \\
\text { PHD }\end{array}$ & THT & private & Sep-04 & 1 & Rockdale Run & 〜191 \\
\hline Jim Smith Farm & JSF & private & Sep-04 & 3 & Rockdale Run & 185 \\
\hline Poor House Farm & PHS & Berkeley Co. & Nov-03 & 7 & Rockdale Run & 184 \\
\hline $\begin{array}{c}\text { Tuscarora Creek } \\
\text { above PHS }\end{array}$ & TPH & Berkeley Co. & Apr-04 & 3 & Rockdale Run & 182 \\
\hline Mike Burkhart Farm & DBR & private & Jul-04 & 4 & Rockdale Run & 182 \\
\hline Dodson Farm & DOD & private & Sep-04 & 3 & Elbrook & 178 \\
\hline Burkhart Spring & BRK & private & Nov-03 & 8 & Elbrook & 172 \\
\hline Bella Vista Farm & BEL & private & Nov-03 & 8 & Elbrook & 182 \\
\hline $\begin{array}{c}\text { Tuscarora Creek } \\
\text { above BEL }\end{array}$ & TBE & private & Apr-04 & 3 & Elbrook & $\sim 182$ \\
\hline Roach Farm Spring & TFS & private & Nov-04 & 2 & Elbrook & 164 \\
\hline Olean Spring & OLN & private & Nov-04 & 8 & Elbrook & 153 \\
\hline $\begin{array}{c}\text { Tuscarora Creek } \\
\text { above OLN }\end{array}$ & TOL & private & Apr-04 & 2 & Elbrook & $\sim 153$ \\
\hline Kilmer Spring & KMR & $\begin{array}{c}\text { City of } \\
\text { Martinsburg }\end{array}$ & Nov-03 & 8 & Conococheague & 144 \\
\hline $\begin{array}{c}\text { Tuscarora Creek } \\
\text { above KMR }\end{array}$ & TKS & $\begin{array}{c}\text { City of } \\
\text { Martinsburg }\end{array}$ & Nov-03 & 5 & Conococheague & 149 \\
\hline Water Street & WAT & $\begin{array}{c}\text { City of } \\
\text { Martinsburg }\end{array}$ & Nov-03 & 8 & Conococheague & 124 \\
\hline $\begin{array}{c}\text { Tuscarora Creek } \\
\text { above WAT }\end{array}$ & TWA & $\begin{array}{c}\text { City of } \\
\text { Martinsburg }\end{array}$ & Apr-04 & 2 & Conococheague & $\sim 124$ \\
\hline
\end{tabular}


CR represents stream samples and SP is the code for spring samples. BRK-SP01A, for example, refers to a spring sample taken from Burkhart Spring during the first sampling round.

Many of the names used for the springs in this study are convenient names, not the historical ones. Much of the information obtained for these springs was colloquial, and the names used for this project often reflect the ownership of the land, rather than any historical usage. Little data exist for many of these springs, and many of them are not included in any state or federal database. The exceptions to this are Kilmer (KMR), Water Street (WAT), Olean (OLN) and Burkhart (BRK) springs, which have been sampled by the USGS (Table 4). There is some doubt as to whether the springs sampled for the project are the same springs included in the databases. There are at least two other springs near WAT, and the spring identified as DT Burkhart may be BRK, DBR or a spring not identified for this project.

\subsection{Spring descriptions}

These descriptions are arranged from upstream to downstream relative to Tuscarora Creek.

- NWM- This spring issues from rocks and flows into an open pool. The spring is eroded into Tuscarora Creek stream deposits, and is immediately adjacent to Tuscarora Creek. This is the upper most site sampled for the project. Upstream of this point, Tuscarora Creek is an intermittent stream. 
Table 4: Summary of sites included in other databases (McColloch 1986; USGS 2005).

\begin{tabular}{cccc}
\hline Project Code & Spring Name (McColloch 1986) & State ID & USGS ID \\
\hline KMR & Kilmer & Ber-0251 & 392812077585900 \\
WAT & Martinsburg Water Supply & Ber-0221 & 392704077573900 \\
Spring & DT Burkhart & Ber-0246S & 392806078024700 \\
BRK or DBR & DT Burkhart & Ber-0633S & 392812078020201 \\
OLN & - & Ber-0533S & 392748078003202 \\
OLN & - & Ber-0632S & 392746078003301 \\
\hline
\end{tabular}


- PHU- A springhouse has been constructed over the spring. The spring is protected with wooden doors covering the spring. The floor of the spring is covered in coarse sand and has pressure boils indicated by moving sand. The water is used by the landowners for drinking water. The spring is at the base of a low ridge, with Tuscarora Creek to the east. The water discharges from a pipe at the base of the springhouse and flows into Tuscarora Creek.

- PHD- This spring has a springhouse constructed over it. It is located on the same property as PHU. This spring discharges from the springhouse both from a pipe and as a series of small flows. Both PHU and PHD are in a topographic low adjacent to Tuscarora Creek.

- JSF- There is a bedrock outcrop with a pool from which the water flows. A concrete wall has been constructed around the source, forcing the flow into a springhouse. The flow remains channelized and the water flows through a concrete spillway. The bottom of the pool has a sandy bottom. The landowner reports the need to periodically clean sand out of the spring and springhouse. The spring is turbid during storm events. An intermittent spring joins the flow of this spring below the sampling point. This spring is well above the level of Tuscarora Creek.

- PHS- There is a springhouse constructed over the apparent source for PHS. There is no water in the springhouse. The flow has been piped underground from site to pond. There is a vertical standpipe for obtaining depth to water measurements. The water discharges into a nearby pond after flowing through PVC pipe. This site was not running July 2004. 
- DBR- There is a springhouse constructed over the spring. The spring appears to discharge from a fissure in a rock outcrop within the springhouse. The bottom is fine sand and silt. The spring flows through the spring house, through a culvert under a nearby road and onto the property on which BRK is located, joins flow with BRK and several other seeps and undifferentiated flows before reaching Tuscarora Creek.

- BRK-There is a small springhouse constructed over the spring. The spring discharges from the base of the springhouse, and into a concrete sluiceway for the first few meters. The spring then flows through a field and joins DBR. The spring is used by the landowners as a non-potable water source. The field is marshy.

- DOD- There is a springhouse constructed over the spring. The spring flows out of the springhouse, down a spring run, through a culvert under a road, and joins Tuscarora Creek. The spring is used by a local homeowner as a water supply. $\mathrm{DBR}, \mathrm{BRK}$ and DOD are located in a low area, near where the stream turns from flowing parallel to strike to flowing perpendicular to strike.

- BEL- A springhouse is constructed over the spring. The spring appears to rise in several places within the springhouse. The spring water visually degasses as it reaches the surface. The spring flows through a developed channel and into a pond. The overflow from the pond flows into Tuscarora Creek. Some water is used by the landowners and pumped out of the springhouse. 
- TFS- The spring discharges from the base of a rock outcrop. The spring and spring run are undeveloped. The spring is located in a field that has at least one wet-weather spring, and other small springs and seeps.

- OLN- A springhouse is constructed over the spring. The spring appears to originate from several places, as evidenced by pressure boils within the springhouse. The substrate is sand sized particles with some bedrock visible. The spring flows through a developed spring run and into Tuscarora Creek.

- KMR- There are three springhouses located on the property. The springhouse that is most upstream (relative to Tuscarora Creek) is abandoned and beginning to collapse. The second springhouse has a sandy substrate and sand boils. Water samples for the project were collected from this spot. The water then flows by underground pipe into the third springhouse. From this point, all of the water flows by gravity feed to the City of Martinsburg treatment facility.

- WAT- The water at this site discharges from a pipe as well as from numerous seeps and small flows along a bank. The actual source of the water is unclear at this site. The site has been developed and the original spring source is impossible to determine. This spring is located in downtown Martinsburg, WV, and is believed to be the spring known historically as Martinsburg Water Supply Spring. 


\section{Methods}

Ninety-three water samples were collected from twenty sites within Tuscarora Creek watershed between November 24, 2003 and January 6, 2005. The fieldwork consisted of (a) obtaining screening parameters, (b) collecting water samples for major ion analysis and (c) flow measurements. The data analysis involved (a) statistical analysis, (b) calculation of equilibrium-based parameters, such as $\mathrm{SI}_{\mathrm{c}}$ and (c) calculating discharge from field flow gaging.

\subsection{Field methods}

$\mathrm{SC}, \mathrm{pH}$, temperature and alkalinity data were collected on-site. Standard equipment was used for the measurement of these parameters (Appendix C). The equipment for measuring $\mathrm{pH}$ and $\mathrm{SC}$ was calibrated daily before sampling. The SC equipment was calibrated using a $1409 \mu \mathrm{S} / \mathrm{cm}$ potassium chloride solution. The $\mathrm{pH}$ probe was calibrated using standard 4 and $7 \mathrm{pH}$ solutions.

All of the water samples collected were analyzed for alkalinity by titrating to two endpoints of pH 4.2 and 3.9 (APHA 2000). The titration was performed on-site, to minimize any time-based inaccuracies including degassing and microbial growth within the sample. The titration was performed with a digital titrator and $1.6 \mathrm{~N}$ sulfuric acid (Appendix C). The data were recorded as clicks of the digital titrator and $\mathrm{pH}$, and then converted to $\mathrm{mg} / \mathrm{L}$ as $\mathrm{CaCO}_{3}$ by the following calculation:

Alkalinity $\left(\mathrm{mg} / \mathrm{L}\right.$ as $\left.\mathrm{CaCO}_{3}\right)=\frac{2 B-C}{800} \times \frac{(1.6 N \text { acid }) 50,000}{50 m L \text { of sample }}$

$\mathrm{B}=$ titrator clicks to reach $\mathrm{pH}$ of 4.2

$\mathrm{C}=$ titrator clicks to reach $\mathrm{pH}$ of 3.9 
800 is the conversion from titrator clicks to $\mathrm{mL}$, and 50,000 is the conversion from equivalents of acid to $\mathrm{CaCO}_{3}$. The alkalinity can be converted to $\mathrm{mg} / \mathrm{L}$ as $\mathrm{HCO}_{3}{ }^{-}$by multiplying the result by 0.61 (Thomas and Lynch 1960; APHA 2000).

The samples collected for laboratory analysis were filtered with a tortuous-path Whatman PVDF 0.45- $\mu \mathrm{m}$ filter. The samples to be analyzed for cations were preserved with $\mathrm{HNO}_{3}{ }^{-}$, and both anion and cation samples were kept cold until analysis.

\subsection{Laboratory analytical methods and detection limits}

Water samples were collected for major cation and anion analysis by the National Research Center for Coal and Energy (NRCCE) analytical laboratory, located at West Virginia University. The cations were analyzed with an inductively coupled plasma optical emission spectrometer (ICP-OES). The anions were analyzed using a colorimetric method for the first six rounds. The lab switched to ion chromatography (IC) for the last two rounds of sampling. There are two method detection limits (MDL) associated with each method, both the in-house detection limit (Appendix C) determined by the NRCCE, and the one designated by the EPA (EPA 1983; EPA 1993). The NRCCE MDLs for sulfate decreased throughout the project because of on an ongoing effort by the lab to lower the in-house detection limit.

\subsection{Quality control}

Several techniques were used to minimize and determine errors in data collection. When error could not be minimized, these quality control measures served to evaluate the data quality. Blind duplicate samples were included in every sample round submitted to the NRCCE. Different sampling locations were used for each duplicate. The COV for 
all of the analytes, with the exception of nitrate, was below 5\%. Nitrate had an average COV of $13.5 \%$. The low COV for all of the analytes suggest that there is very good duplication of the data, and thus a high level of precision. The higher COV for nitrate suggests a lower precision for this analyte. The COV for nitrate decreased for the last two sampling rounds, at the same time the NRCCE switched from a colorimetric analysis to IC.

Equipment blank samples, filled with filtered deionized water in the field, were also included for laboratory analysis. There was an average difference of two orders of magnitude between the samples and the equipment blanks for calcium and magnesium (Table 5). The difference is not as robust for some of the other analytes (iron, potassium, silica, manganese), but this can be attributed to the low concentrations found in the samples (Table 5). In addition, the method detection limit is close to the concentrations measured, and many of samples were below detection (Table 5). Based on the filter blank samples collected, the filtering process did not affect the results.

Cation and anion standards were created and submitted to the lab with the first round of samples. The cations have a statistically significant correlation coefficient (0.99) between the known standard and the measured concentrations. The lab underreported higher concentrations of sulfate, but there is a good correlation for the levels detected during the sampling period (Figure 7). The lab decreased the MDL for sulfate throughout the sampling period, suggesting that the later data may be more accurate (Appendix C).

The nitrate concentrations were significantly underreported by the lab (Figure 7). However, bicarbonate is the dominant anion and the primary focus of this project is on 
Table 5: Comparison between average measured concentrations and equipment blank samples.

\begin{tabular}{ccccccccccc}
\hline & $\begin{array}{c}\mathrm{Ca} \\
(\mathrm{mg} / \mathrm{L})\end{array}$ & $\begin{array}{c}\mathrm{Mg} \\
(\mathrm{mg} / \mathrm{L})\end{array}$ & $\begin{array}{c}\mathrm{Na} \\
(\mathrm{mg} / \mathrm{L})\end{array}$ & $\begin{array}{c}\mathrm{K} \\
(\mathrm{mg} / \mathrm{L})\end{array}$ & $\begin{array}{c}\mathrm{Fe} \\
(\mathrm{mg} / \mathrm{L})\end{array}$ & $\begin{array}{c}\mathrm{Mn} \\
(\mathrm{mg} / \mathrm{L})\end{array}$ & $\begin{array}{c}\mathrm{SiO}_{2} \\
(\mathrm{mg} / \mathrm{L})\end{array}$ & $\begin{array}{c}\mathrm{SO}_{4} \\
(\mathrm{mg} / \mathrm{l})\end{array}$ & $\begin{array}{c}\mathrm{Cl} \\
(\mathrm{mg} / \mathrm{L})\end{array}$ & $\begin{array}{c}\mathrm{NO}_{3} \\
(\mathrm{mg} / \mathrm{L})\end{array}$ \\
\hline $\begin{array}{c}\text { Average field } \\
\text { sample } \\
\text { concentration }\end{array}$ & 86.4 & 22.6 & 7.5 & 2.6 & 0.19 & 0.18 & 4.85 & 23.8 & 14.0 & 4.15 \\
$\begin{array}{c}\text { Detected/ } \\
\text { collected* }\end{array}$ & $7 / 9$ & $2 / 9$ & $3 / 9$ & $0 / 9$ & $1 / 9$ & $0 / 9$ & $3 / 9$ & $4 / 9$ & $4 / 9$ & $2 / 9$ \\
$\begin{array}{c}\text { Average } \\
\text { detected } \\
(\mathrm{mg} / \mathrm{L})^{* *}\end{array}$ & 0.7 & 0.2 & 0.7 & 0 & 0.1 & 0 & 2 & 4.1 & 0.7 & 0.1 \\
${ }^{*}$ Number of blank samples collected that exceeded MDL/number of blank samples collected & & \\
${ }^{* *}$ Average concentration of blank samples that exceeded MDL
\end{tabular}



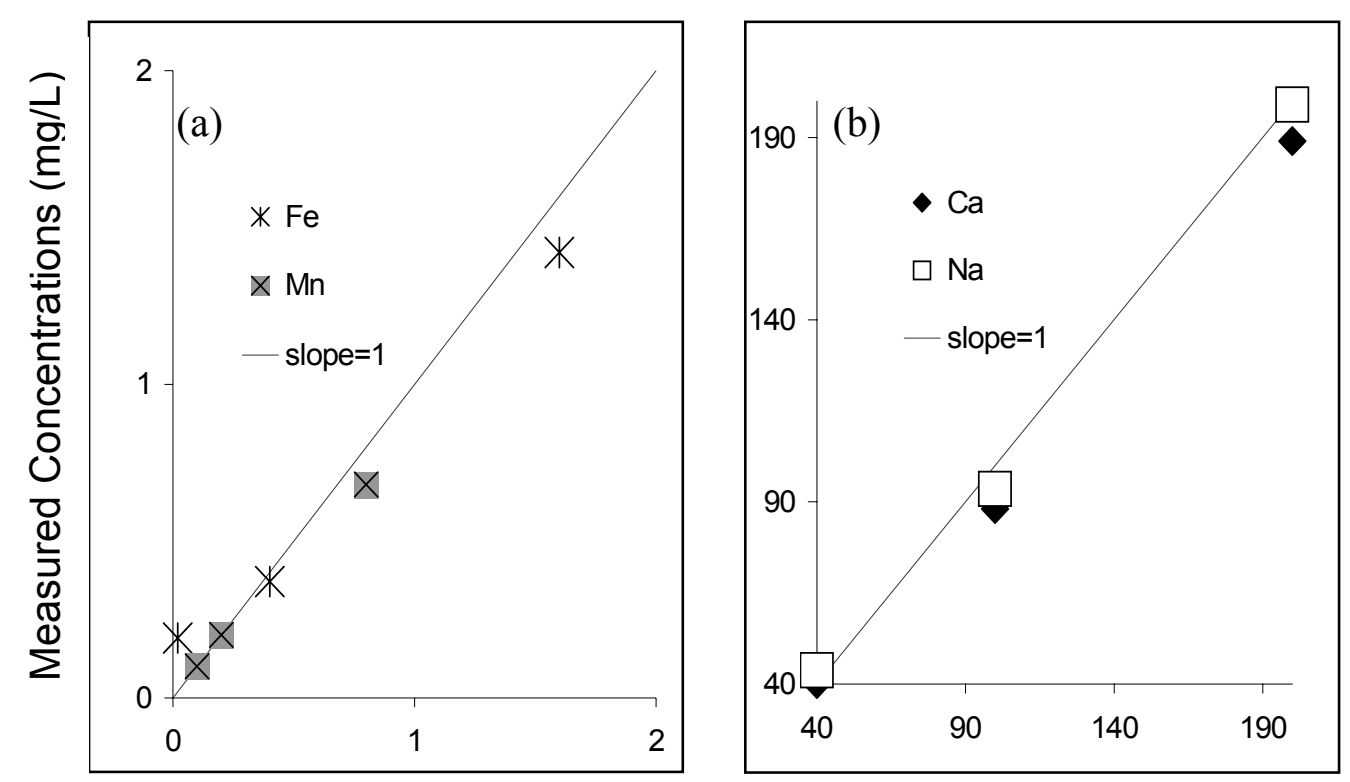

Known concentrations (mg/L)

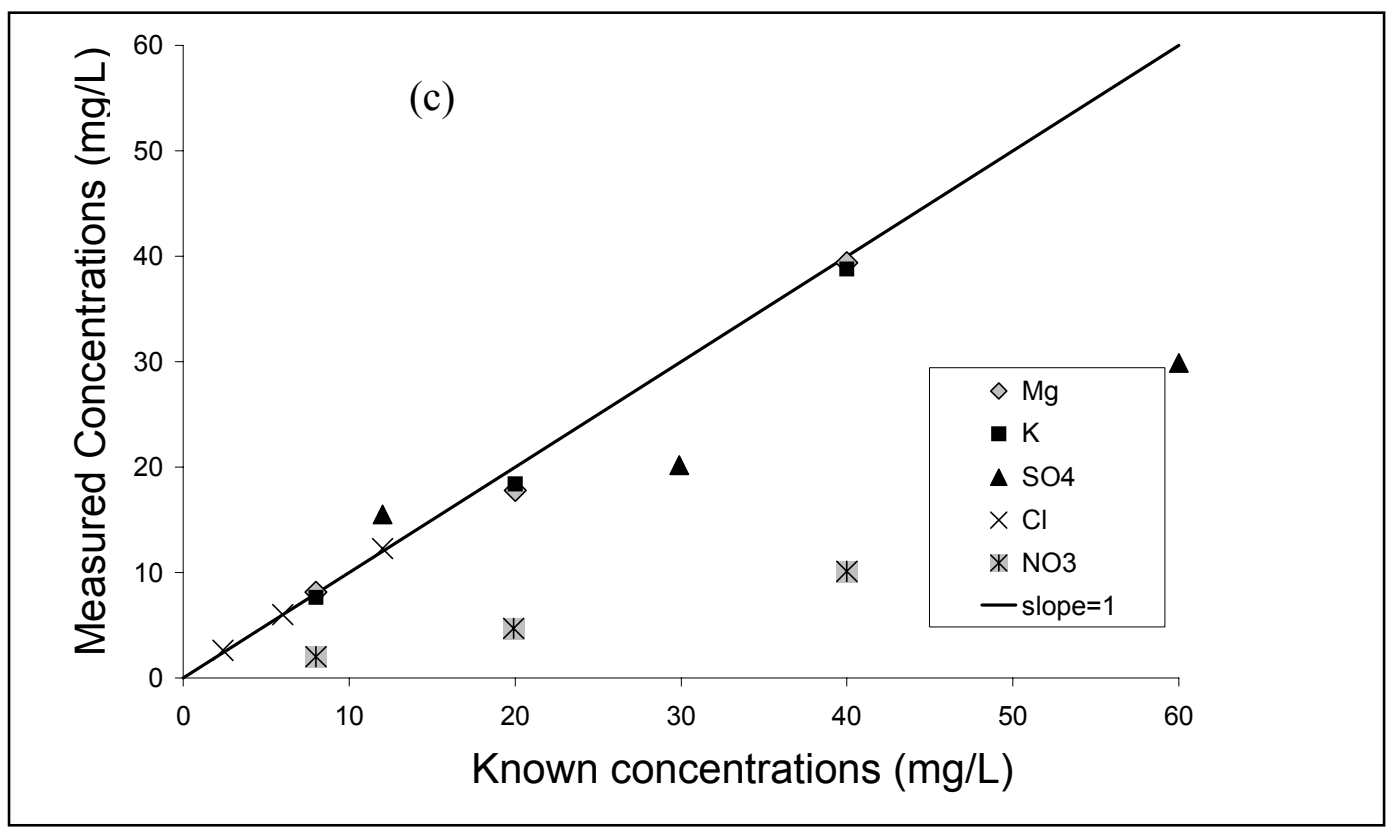

Figure 7: Comparison between known standards and the measured concentrations. 
carbonate geochemistry. The underreporting of anions, specifically sulfate and nitrate, is probable but does not have a large impact on the conclusions of this work. The precision and accuracy of the nitrate data are lower than the other analytes.

Calculating the charge balance of each sample provided another check on the quality and completeness of the laboratory data. The charge balance was determined using the Visual MINTEQ program (Gustafsson 2005). The mean charge balance for all of the samples is $5.5 \%$, and the median is $4.1 \%$. The histogram is skewed to the left, with the bulk of the samples having a charge balance of less than $6 \%$ (Figure 8 ). The box and whisker plot provides a visual estimate of the charge balance distribution (Figure 8). The caps at the end of each box indicate the minimum and maximum, the box is defined by the lower and upper quartiles, and the line in the center of the box is the median (Moore 2000).

Overall, the quality control measures taken indicate the data are acceptable for a project of this nature. The duplicates are consistent, and with the exception of nitrate, the known and measured concentrations are similar. The charge balances are generally low.

\subsection{Flow measurements}

Not all sites have geometry conducive to gaging, but discharge data were collected wherever possible. The flow was calculated using the sum of all of measured flows for each stream or spring cross-sectional profile (Gordon and others 1992). The discharge of several of the springs was measured throughout the sampling period. Two low-flow seepage runs, measuring the flow of Tuscarora Creek and some of the springs, were completed in October and November 2004. 


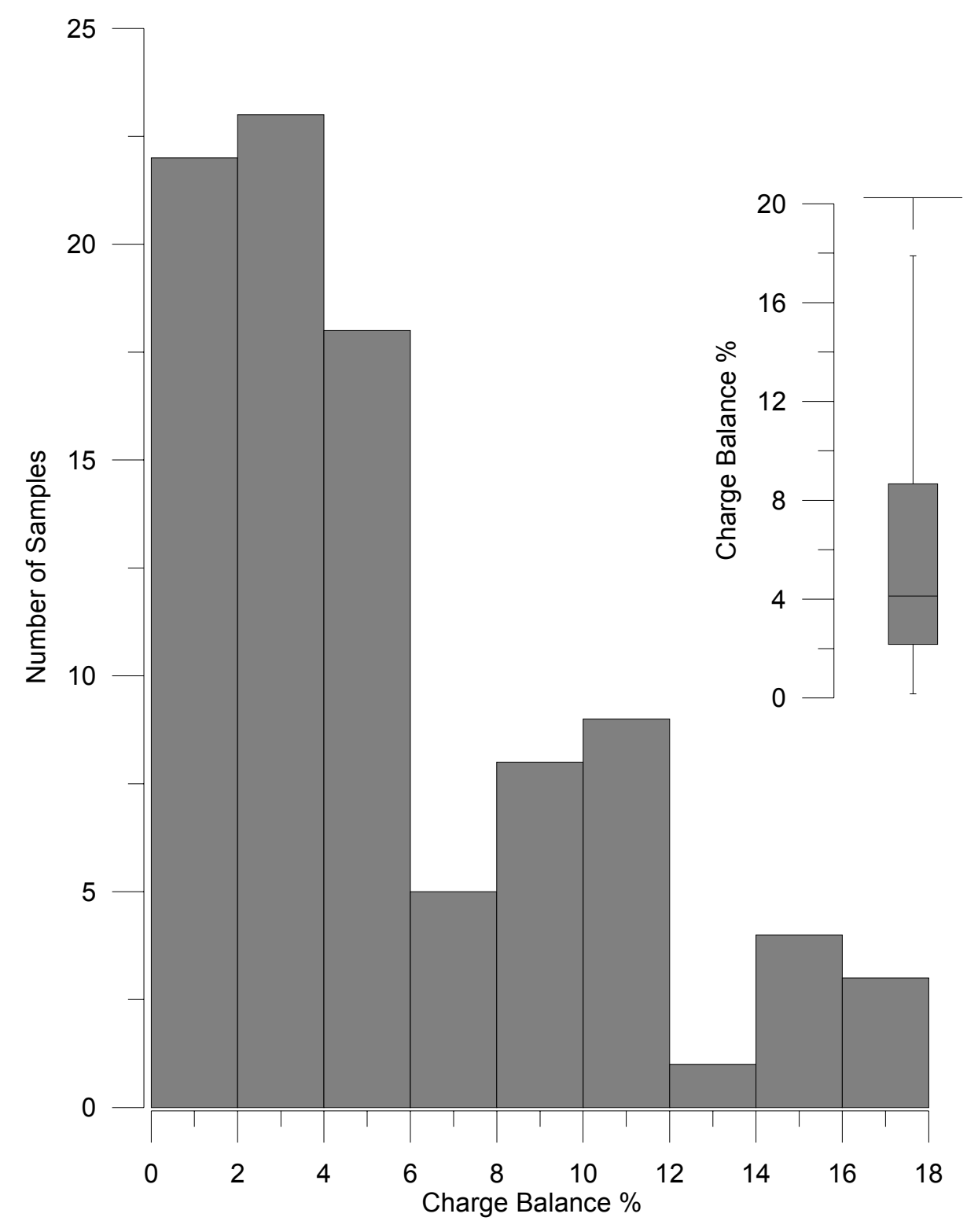

Figure 8: Histogram, box and whisker plot of charge balance for all water samples. 


\subsubsection{Quality control of flow measurements}

The greatest error associated with flow meters involves the operator and lessthan-ideal cross-sectional channel profiles. Increasing the number of readings taken across a profile can help t minimize some of this error (Gordon and others 1992). To quantify the errors inherent in gaging, repeated measurements were taken at several different sampling sites.

The site with the lowest calculated error (4\%) was not within Tuscarora Creek watershed and was wider and had a higher flow than the other two sites used for quality control. The channel bottom was not smooth, but the reach measured was reasonably straight. The width of the site allowed for more measurements to be collected (21), which probably accounts for the low percent error.

BEL had the second lowest percent difference (7\%). The spring run has been modified and is essentially a straight reach with a flat profile. However, all of the flow is centered in one part of the reach, and it is not possible to collect very many readings (8).

WAT had the highest percent error (36\%). This channel is approximately one meter wide, shallow and there are no long straight reaches to measure discharge. The combination of the narrow width and the less-than-ideal reach probably combine to contribute to the high error. More measurements were taken here (14), but they were very closely spaced.

The range of errors suggests that site setting is a larger contributor to inaccuracy than operator error. Where a channel is wide, and the reach is straight, the measurements are more precise. To quantify operator error, different operators measured the same site 
on the same day. For low-flow seepage run measurements of Tuscarora Creek, the same site was also measured at the beginning and end of the day, to quantify any time variability of flow. The two teams had a percent difference of $4 \%$ and $7 \%$ based on beginning and end-of-day measurements of the same spot. This suggests that the data collected are consistent between teams. The two separate low flow seepage runs had consistent trends, thus providing a check on the precision of the data.

\subsection{Methods for data analysis}

Alkalinity, discussed previously, and hardness were two parameters used for data analysis. Hardness is reported as equivalents or $\mathrm{mg} / \mathrm{L}$ of $\mathrm{CaCO}_{3}$. The calculation used for this project uses the molecular weight of $\mathrm{CaCO}_{3}$ divided by the molecular weight of $\mathrm{Ca}^{2+}$ and then multiplied by the measured concentration. The same procedure is repeated with $\mathrm{Mg}^{2+}$ and the results are summed.

Equivalents of $\mathrm{CaCO}_{3}=2.5\left(\mathrm{mg} / \mathrm{L} \mathrm{Ca}^{2+}\right)+4.1\left(\mathrm{mg} / \mathrm{L} \mathrm{Mg}^{2+}\right)$

(Drever 1997)

To determine the land use within Tuscarora Creek watershed, the GapLULC was used (Table 2). This grid was created from satellite imagery in 1993 and 1994. The data were then reclassified into urban and non-urban for ease of analysis (Table 2). The grid and all shapefiles were clipped to the extent of Tuscarora Creek watershed. The select by location tool was used to select attributes such as roads and urban areas, derived from GapLULC grid, that were within a set distance of the springs. 


\section{Results}

Chemical sampling began in November 2003 and was completed January 2005. Sampling locations were added throughout the sampling period as new locations were found or access was granted (Table 6). Thirteen springs and seven sites along Tuscarora Creek were sampled. Discharge measurements were collected from some springs. Two separate low flow seepage runs were completed for Tuscarora Creek.

\subsection{Chemical data}

\subsubsection{Overview}

The springs sampled on Tuscarora Creek have a similar chemistry when compared to each other (Table 7). This is consistent with a karst watershed, in which the dissolution of limestone is the dominant chemical process. There are low, relatively consistent concentrations of silica and potassium throughout the watershed (Table 7). Most of the spring waters were below detection for iron and manganese (Table 7).

The average water chemistry of all of the springs sampled was plotted on a piper diagram (Figure 9) which visually displays how water chemistry is classified based on different hydrochemical facies (Drever 1997). The springs of Tuscarora Creek watershed are calcium and bicarbonate types (Drever 1997)

Magnesium is also a major cation, which is expected as many of the rocks in the study area are both limestone and dolomite (Table 1). Sulfate, sodium, chloride, nitrate and potassium are minor constituents. 
Table 6: Dates and sites sampled on Tuscarora Creek watershed.

\begin{tabular}{|c|c|c|c|c|c|c|c|c|c|}
\hline & Site ID & Nov-03 & Feb-04 & Apr-04 & Jun-04 & Jul-04 & Sep-04 & Nov-04 & Jan-05 \\
\hline \multirow{13}{*}{$\begin{array}{c}\text { spring } \\
\text { samples }\end{array}$} & BEL & $x$ & $x$ & $x$ & $x$ & $x$ & $x$ & $x$ & $x$ \\
\hline & BRK & $x$ & $x$ & $x$ & $x$ & $x$ & $x$ & $x$ & $x$ \\
\hline & DBR & & & & & $X$ & $X$ & $X$ & $x$ \\
\hline & DOD & & & & & & $x$ & $x$ & $x$ \\
\hline & JSF & & & & & & $x$ & $x$ & $x$ \\
\hline & KMR & $x$ & $x$ & $x$ & $x$ & $x$ & $x$ & $x$ & $x$ \\
\hline & NWM & & & & & $x$ & $x$ & $X$ & $x$ \\
\hline & OLN & $X$ & $X$ & $x$ & $X$ & $x$ & $X$ & $x$ & $X$ \\
\hline & PHD & & & & & & $x$ & $x$ & $x$ \\
\hline & PHS & $x$ & $x$ & $x$ & $x$ & & $x$ & $x$ & $x$ \\
\hline & $\mathrm{PHU}$ & & & & & & $x$ & $x$ & $x$ \\
\hline & TFS & & & & & & & $x$ & $X$ \\
\hline & WAT & $X$ & $X$ & $X$ & $X$ & $X$ & $X$ & $X$ & $X$ \\
\hline \multirow{7}{*}{$\begin{array}{c}\text { stream } \\
\text { samples }\end{array}$} & TBE & & & $x$ & $x$ & & $x$ & & \\
\hline & THT & & & & & & $x$ & & \\
\hline & TKS & $x$ & $x$ & $x$ & & & $x$ & & \\
\hline & TNM & & & & & & $x$ & $x$ & \\
\hline & TOL & & & $x$ & $x$ & & $X$ & & \\
\hline & TPH & & & $X$ & $X$ & & $X$ & & \\
\hline & TWA & & & $x$ & $x$ & & & & \\
\hline
\end{tabular}


Table 7: Average water chemistry of Tuscarora Creek watershed springs.

\begin{tabular}{cccccccccccc}
\hline $\begin{array}{c}\text { Spring } \\
\text { Code }\end{array}$ & $\begin{array}{c}\mathrm{Ca} \\
(\mathrm{mg} / \mathrm{L})\end{array}$ & $\begin{array}{c}\mathrm{Mg} \\
(\mathrm{mg} / \mathrm{L})\end{array}$ & $\begin{array}{c}\mathrm{Na} \\
(\mathrm{mg} / \mathrm{L})\end{array}$ & $\begin{array}{c}\mathrm{K} \\
(\mathrm{mg} / \mathrm{L})\end{array}$ & $\begin{array}{c}\mathrm{Fe} \\
(\mathrm{mg} / \mathrm{L})\end{array}$ & $\begin{array}{c}\mathrm{Mn} \\
(\mathrm{mg} / \mathrm{L})\end{array}$ & $\begin{array}{c}\mathrm{SiO}_{2} \\
(\mathrm{mg} / \mathrm{L})\end{array}$ & $\begin{array}{c}\mathrm{SO}_{4} \\
(\mathrm{mg} / \mathrm{l})\end{array}$ & $\begin{array}{c}\mathrm{Cl} \\
(\mathrm{mg} / \mathrm{L})\end{array}$ & $\begin{array}{c}\mathrm{NO}_{3} \\
(\mathrm{mg} / \mathrm{L})\end{array}$ & $\begin{array}{c}\mathrm{HCO}_{3}^{-} \\
(\mathrm{mg} / \mathrm{L})\end{array}$ \\
\hline NWM & 82.4 & 13.4 & 4.83 & 1.72 & $\mathrm{BDL}$ & $\mathrm{BDL}$ & 4.10 & 20.2 & 6.70 & 1.01 & 331 \\
PHU & 82.7 & 28.8 & 2.71 & 1.92 & $\mathrm{BDL}$ & $\mathrm{BDL}$ & 5.29 & 35.5 & 5.25 & 4.98 & 331 \\
PHD & 87.6 & 30.6 & 2.85 & 2.20 & $\mathrm{BDL}$ & $\mathrm{BDL}$ & 5.62 & 34.8 & 5.25 & 5.15 & 329 \\
JSF & 48.5 & 12.2 & 8.21 & 1.74 & $\mathrm{BDL}$ & $\mathrm{BDL}$ & 4.95 & 18.1 & 16.3 & 0.59 & 181 \\
PHS & 88.2 & 21.4 & 2.86 & 1.96 & $\mathrm{BDL}$ & $\mathrm{BDL}$ & 4.32 & 18.8 & 5.44 & 2.18 & 329 \\
DBR & 78.8 & 18.8 & 7.34 & 4.21 & 4.48 & $\mathrm{BDL}$ & 4.56 & 26.6 & 11.3 & 3.15 & 265 \\
BRK & 66.1 & 24.1 & 5.40 & 2.03 & $\mathrm{BDL}$ & $\mathrm{BDL}$ & 5.11 & 33.8 & 10.8 & 2.96 & 234 \\
DOD & 75.1 & 22.4 & 1.56 & 1.98 & $\mathrm{BDL}$ & $\mathrm{BDL}$ & 4.85 & 24.6 & 4.04 & 3.63 & 308 \\
BEL & 79.3 & 28.9 & 3.57 & 2.08 & $\mathrm{BDL}$ & $\mathrm{BDL}$ & 5.15 & 19.3 & 7.20 & 5.76 & 318 \\
TFS & 94.2 & 26.0 & 10.4 & 2.45 & $\mathrm{BDL}$ & $\mathrm{BDL}$ & 5.09 & 25.3 & 22.7 & 5.23 & 434 \\
OLN & 96.5 & 24.8 & 4.19 & 3.10 & $\mathrm{BDL}$ & $\mathrm{BDL}$ & 5.20 & 18.6 & 9.17 & 3.79 & 393 \\
KMR & 103 & 22.2 & 8.31 & 2.87 & $\mathrm{BDL}$ & $\mathrm{BDL}$ & 5.34 & 21.2 & 16.4 & 6.34 & 387 \\
WAT & 116 & 23.9 & 24.4 & 3.51 & $\mathrm{BDL}$ & $\mathrm{BDL}$ & 4.29 & 38.1 & 47.0 & 5.67 & 386 \\
\hline BDL=Below laboratory detection limits & & & & & & & \\
\hline
\end{tabular}




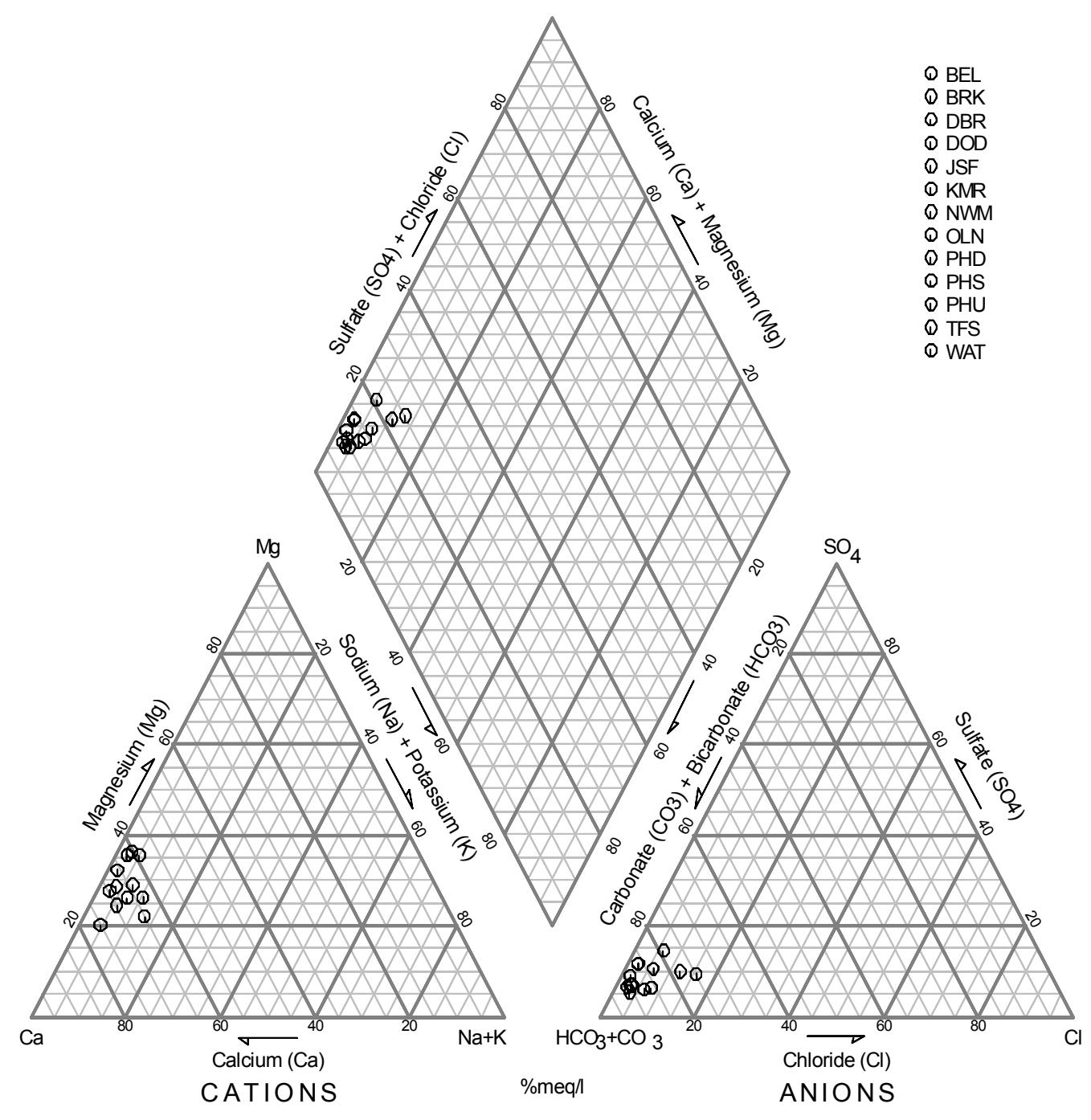

Figure 9: Piper diagram of average water chemistry. 


\subsubsection{Major ions}

The major dissolved cations in the water samples collected from Tuscarora Creek are calcium and magnesium. These are primarily derived from the weathering of carbonate rocks (White 1988). Generally, the concentration of calcium in the sampled spring water increases from the upper watershed to the lower (Figure 10). The upper watershed springs are more variable. From BRK on, the concentration increases (Figure $10)$.

For the six springs for which there is a complete data set, the temporal variability of the calcium concentration can be compared (Figure 11). Most of the springs have higher concentrations in the summer months. KMR and WAT exhibit two peaks, one in the summer months and one in March 2004 (Figure 11).

Calcium and magnesium varies throughout the watershed (Figure 12). JSF has lower average concentrations of calcium and magnesium than the other sites sampled. PHU and PHD have higher magnesium concentrations than the other springs located on the Rockdale Run formation. PHU, PHD and BEL have the highest magnesium concentrations (Figure 13). JSF has higher measured concentrations of magnesium than NWM. The upper springs have a greater range in the data, although it should be noted that many of these springs were not sampled for the entire study period.

\subsubsection{Derived carbonate parameters}

\subsubsection{Hardness}

Higher hardness values are often found in the summer months and have been shown to vary seasonally (White 1988). This is due to higher rainfall in the winter and 


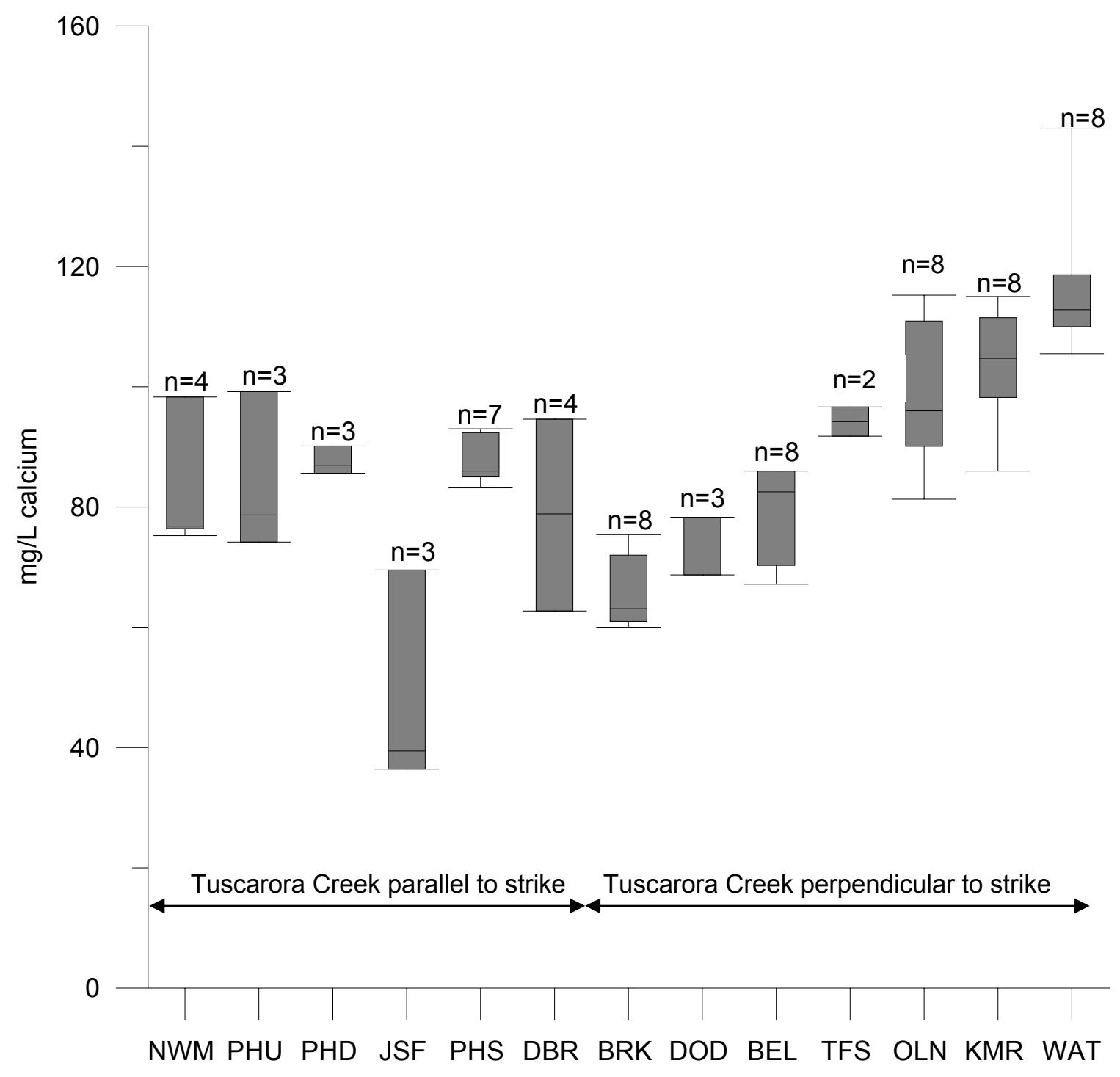

Figure 10: Box and whisker plot of $\mathrm{mg} / \mathrm{L}$ calcium of sampled springs in Tuscarora Creek watershed, $n=$ number of samples. 

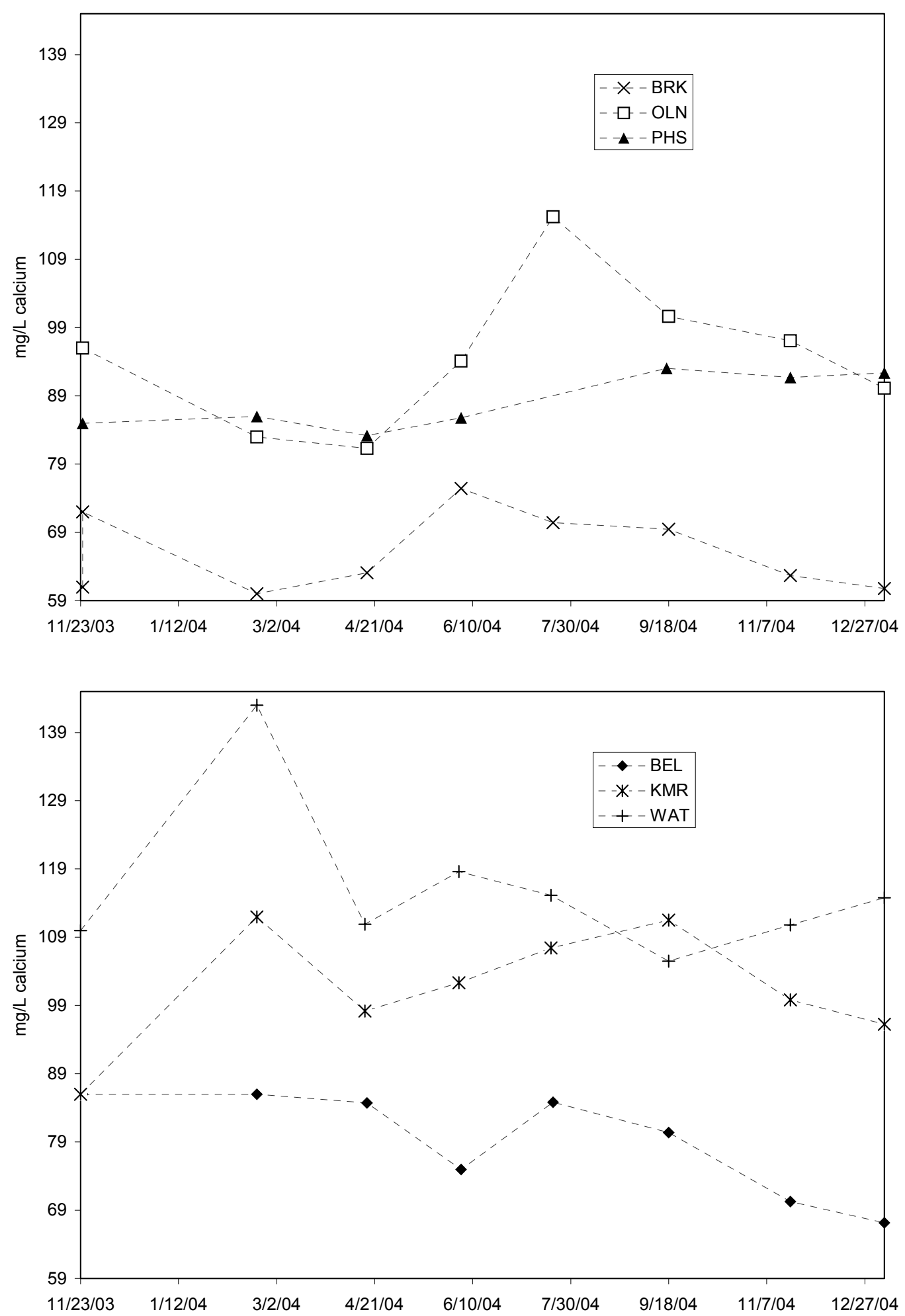

Figure 11: Temporal variability of calcium concentrations of selected Tuscarora Creek watershed springs. 


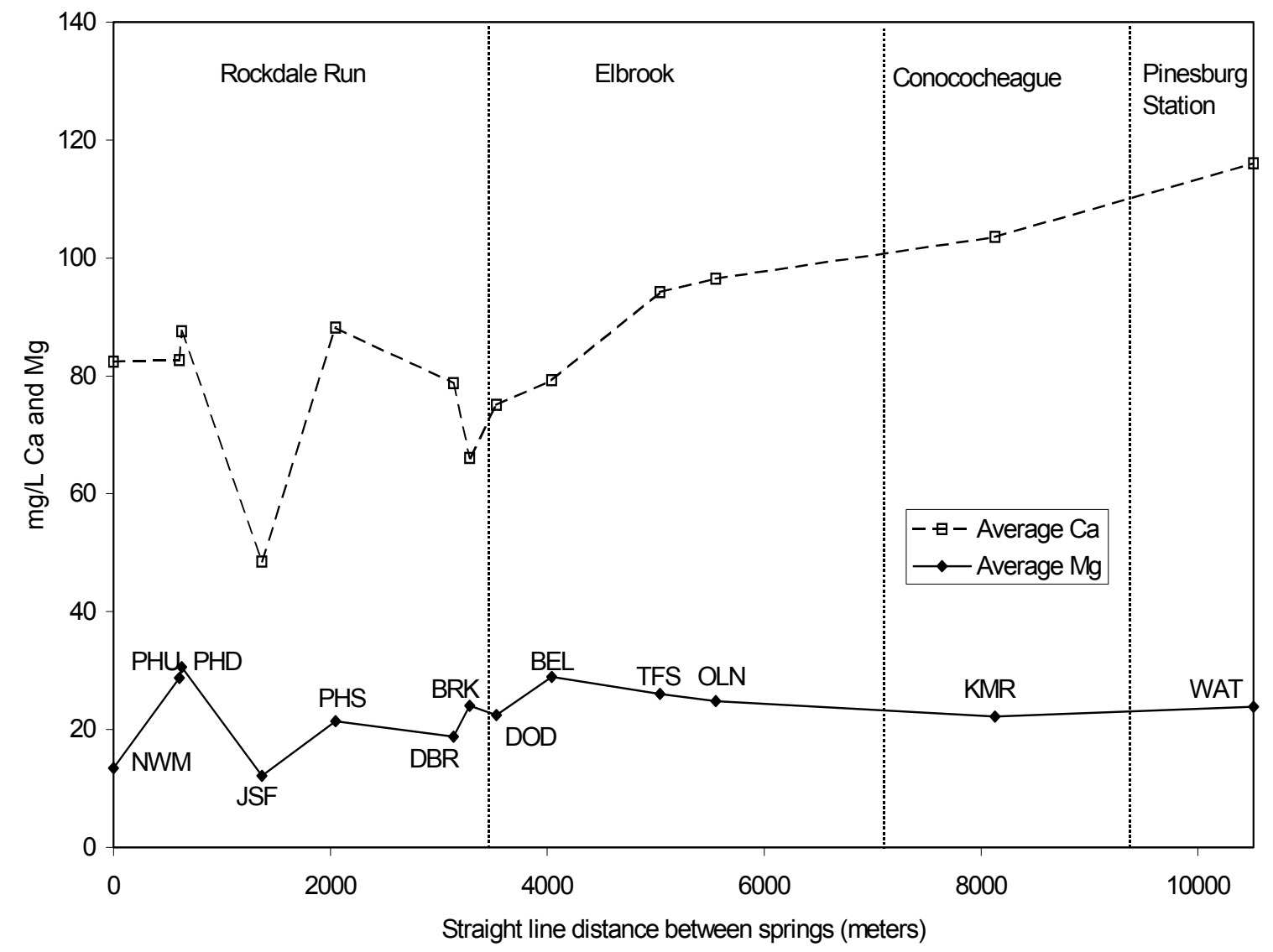

Figure 12: Spatial variability of the average calcium and magnesium concentrations of Tuscarora Creek watershed springs. 


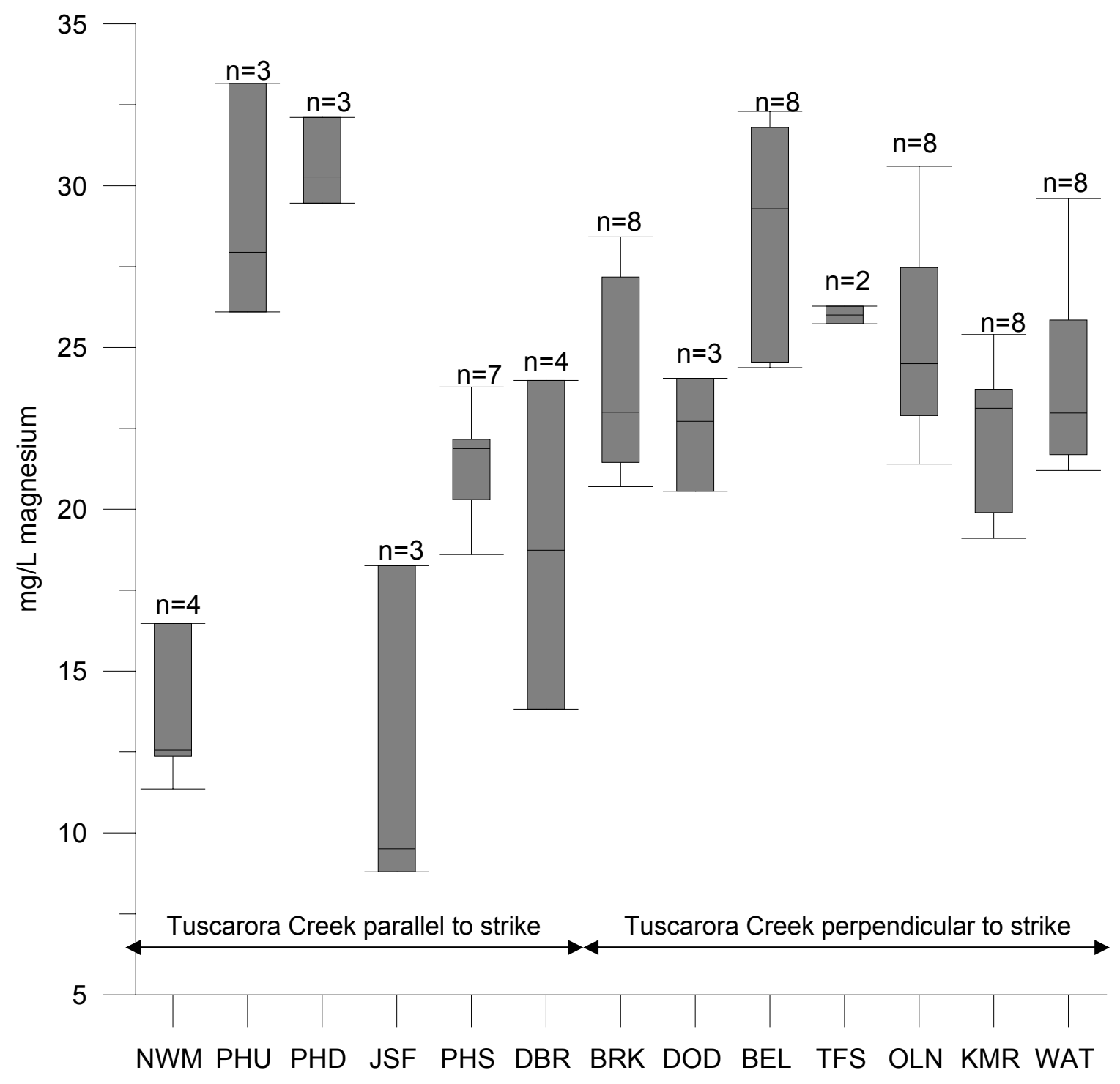

Figure 13: Box and whisker plot of $\mathrm{mg} / \mathrm{L}$ magnesium of sampled springs in Tuscarora Creek watershed, $\mathrm{n}=$ number of samples. 
spring, with subsequent dilution, as well as a peak in $\mathrm{CO}_{2}$ from vegetation in the summer (White 1988). Because calcium and magnesium concentrations vary in ratios throughout the watershed, hardness is used as a way of considering both simultaneously. Aquifers characterized as diffuse flow have been shown to have a lower COV, less than $5 \%$ (Shuster and White 1971). Other studies have characterized aquifers with a COV of hardness greater than $10 \%$ as conduit (Jacobson and Langmuir 1974).

To examine the variability of the hardness, the COV was calculated for the springs on Tuscarora Creek watershed (Table 8). Only six springs on Tuscarora Creek watershed have a full data set. Three of those springs had associated flow data, so that the relationship between discharge and hardness could be graphically examined.

There are several springs on Tuscarora Creek that were not sampled for the entire study period. The COV was calculated, although it should be noted that the data are probably skewed from a deficiency of data points (Table 8). The samples collected in July and September 2004 will have the high and low values associated with summer and winter, so may be a closer approximation to the actual values. TFS is probably skewed low, with only winter data existing for this site (Table 8).

KMR shows a decrease in hardness in the spring and winter, but the highest hardness was recorded in February 2004 (Figure 14). This spring has the highest COV of hardness of the sampled springs.

The hardness was greatest at PHS in September 2004. This site was dry July 2004 and no sample was collected. The lowest hardness was in February 2004. The hardness decreases in the winter of 2004-2005, but not to the lower levels in the winter of 
Table 8: Hardness COV for Tuscarora Creek watershed springs.

\begin{tabular}{cccc}
\hline Project Code & $\begin{array}{c}\text { First Chemical } \\
\text { Sampling Date }\end{array}$ & $\begin{array}{c}\text { \# of chemical } \\
\text { samples }\end{array}$ & Hardness COV\% \\
\hline KMR & Nov-05 & 8 & 39 \\
DOD & Sep-05 & 3 & 19 \\
PHS & Nov-05 & 7 & 13 \\
NWM & Jul-05 & 4 & 12 \\
OLN & Nov-05 & 8 & 12 \\
WAT & Nov-05 & 8 & 10 \\
BEL & Nov-05 & 8 & 10 \\
BRK & Nov-05 & 8 & 10 \\
DBR & Jul-05 & 4 & 9 \\
JSF & Sep-05 & 3 & 7 \\
PHU & Sep-05 & 3 & 5 \\
PHD & Sep-05 & 3 & 3 \\
TFS & Nov-05 & 2 & 3 \\
\hline
\end{tabular}




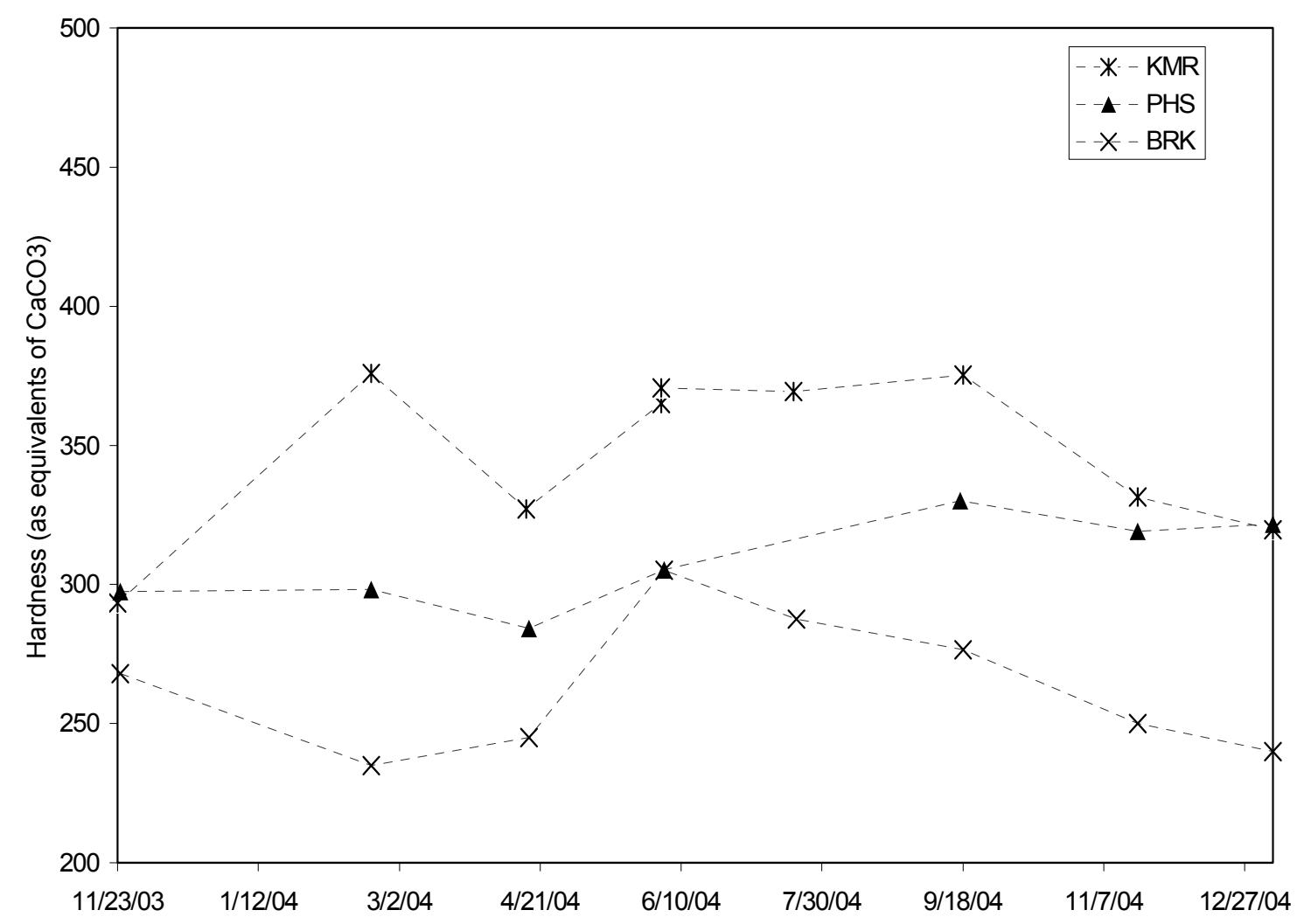

Figure 14: Seasonal variation of hardness for selected Tuscarora Creek watershed springs. 
2003-2004 (Figure 14). The COV is $13 \%$, which is similar to sites characterized as conduit flow springs (Shuster and White 1971).

BRK shows a strong seasonal variation in the hardness (Figure 14). This site has a higher COV than PHS and KMR (Figure 14). Three other sites (BEL, WAT and OLN) were sampled throughout the study period, but discharge data were collected along with chemical data. These sites will be examined individually.

BEL does not exhibit a pronounced seasonal variation in hardness. The highest hardness occurs in February and July 2004 (Figure 15). The hardness does decrease in the winter of 2004-2005 (Figure 15). The hardness at BEL appears to vary with discharge (Figures 15,18). The correlation coefficient, 0.08 , of the six data points for which there is both flow and chemistry data shows no statistically significant correlation between hardness and discharge.

The hardness appears to vary inversely with discharge for OLN with a correlation coefficient of -0.93 (Figure 16,18 ). The hardness has a strong seasonal variability, with the highest concentration occurring July 2004. WAT has a higher hardness value in February 2004 and a more subdued increase in hardness in the summer of 2004 (Figure 17, 18). This spring has a correlation coefficient of -0.8 . The high hardness in February 2004 is interpreted to relate to the low flow of the spring.

Comparing discharge and hardness graphically illustrates the varied response of BEL, WAT and OLN (Figure 18). The $\mathrm{R}^{2}$ values show strength of correlation but not 


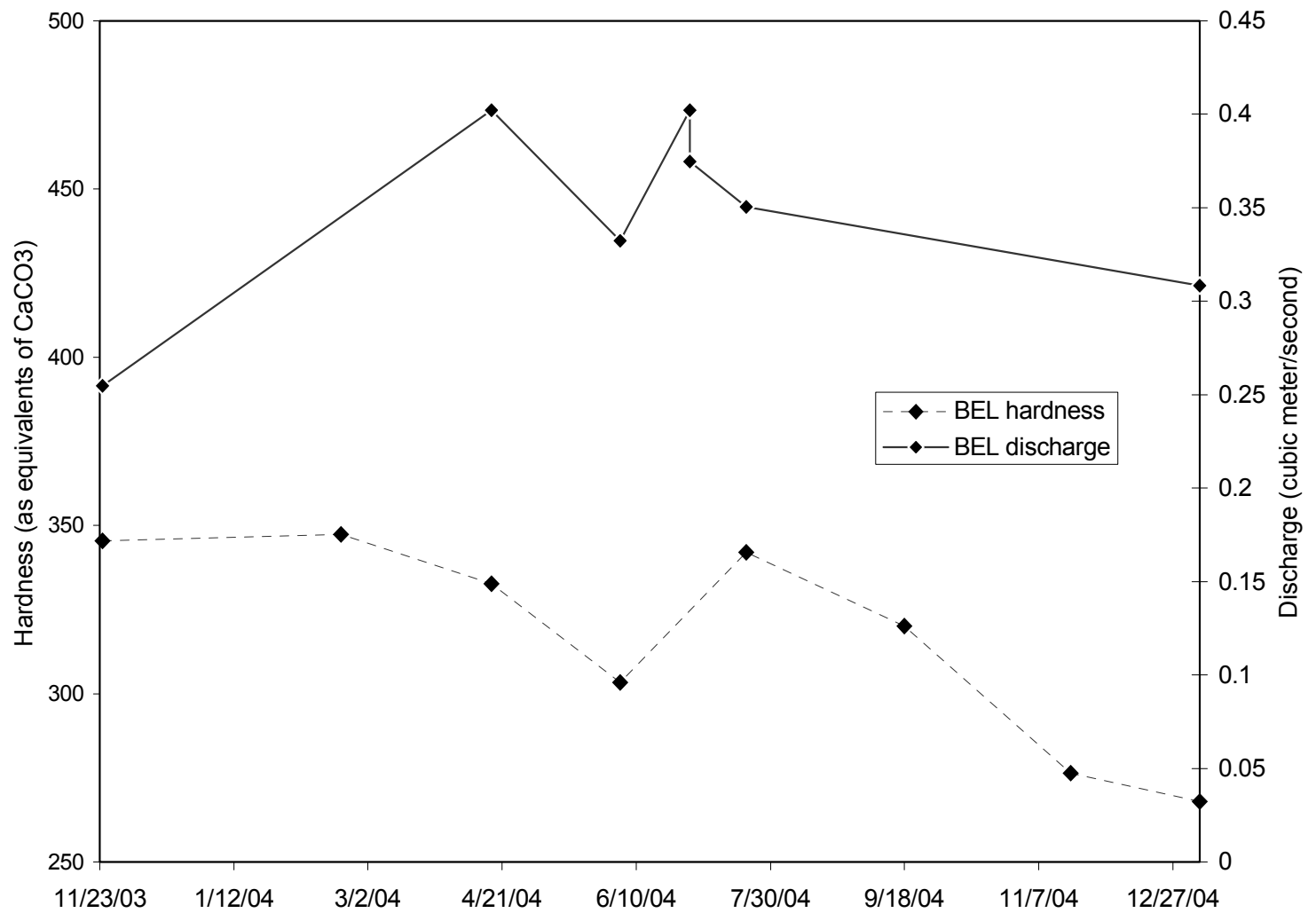

Figure 15: Temporal variability of hardness and discharge of BEL. 


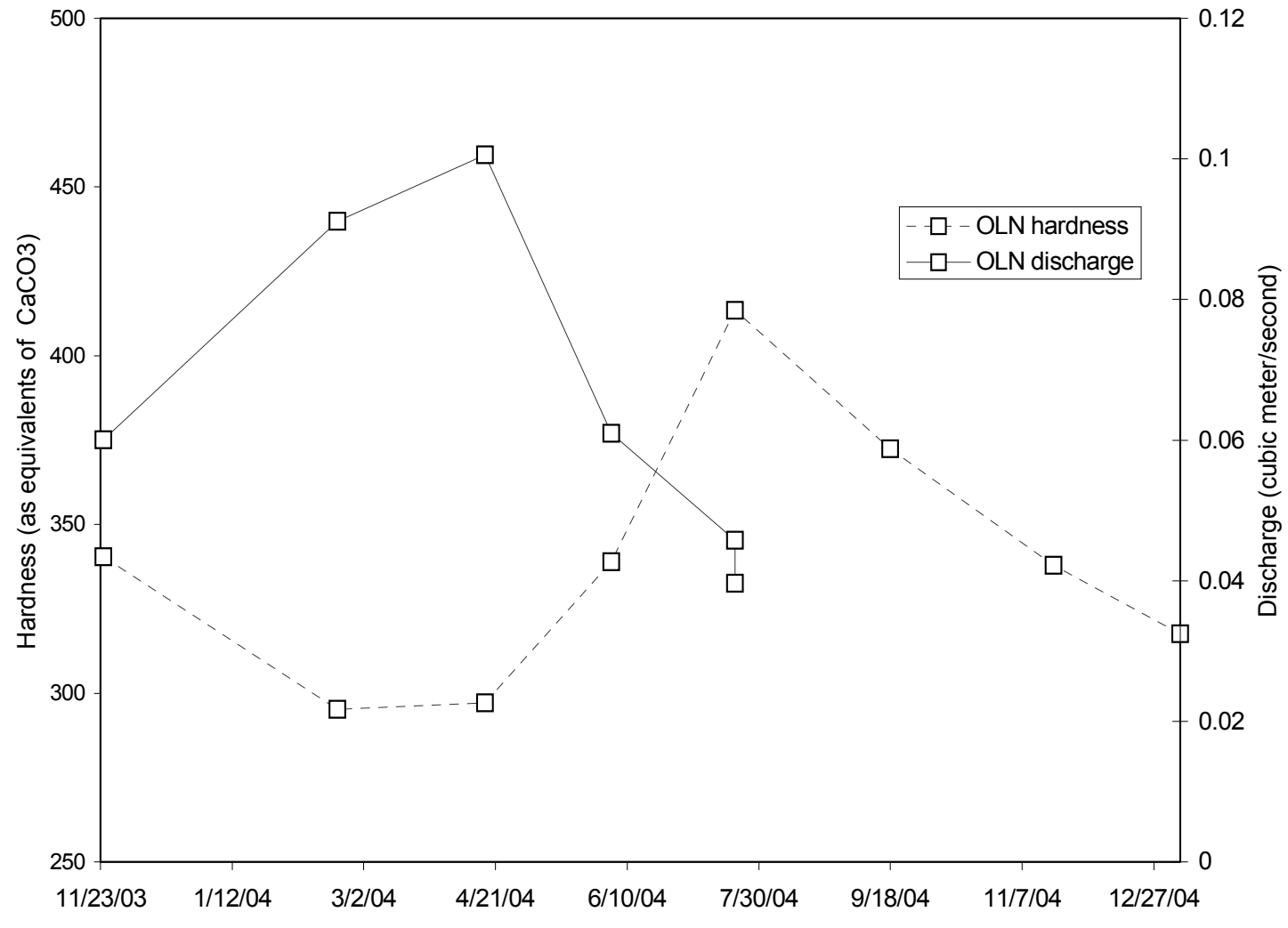

Figure 16: Temporal variability of hardness and discharge of OLN. 


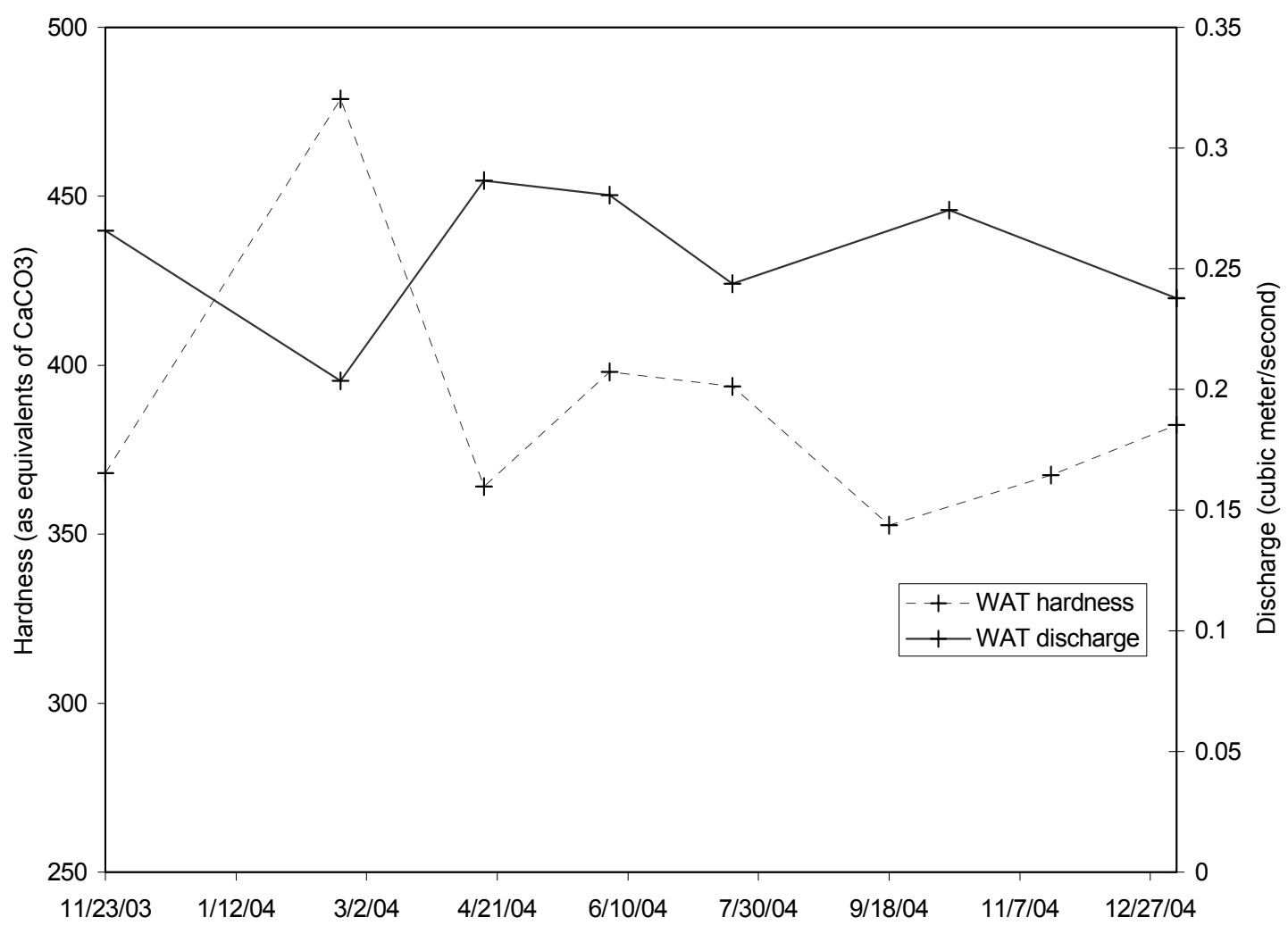

Figure 17: Temporal variability of hardness and discharge of WAT. 


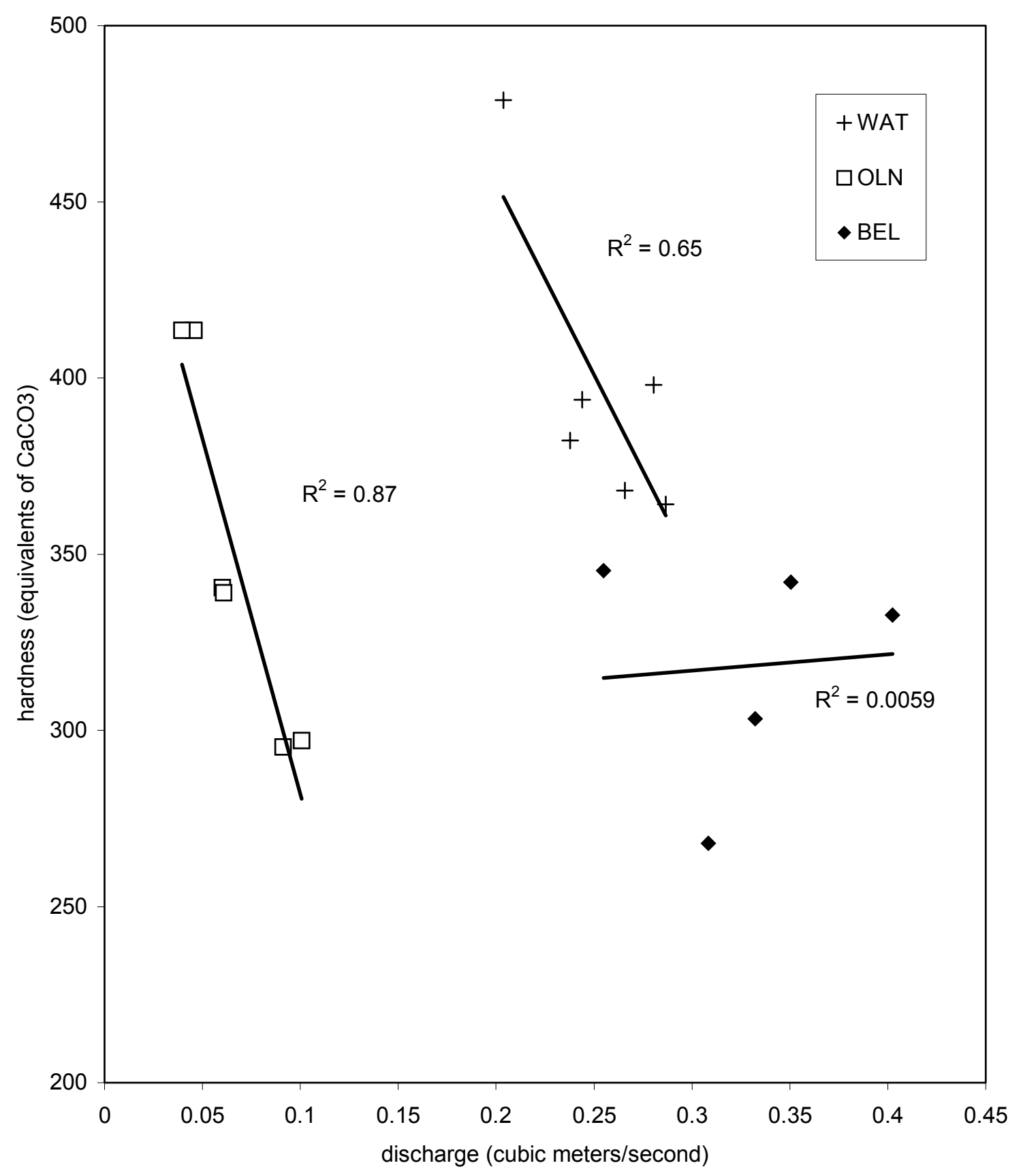

Figure 18: Discharge versus hardness for WAT, OLN and BEL. 
directional correlation. OLN and WAT have a relatively high correlation between hardness and discharge, while BEL the relationship could not be established at BEL with the available data.

\subsubsection{Ca/Mg molar ratio}

The molar ratio of calcium to magnesium is calculated from the measured concentrations of the analytes. A ratio of one indicates that the water was in contact with dolomite, and higher numbers indicate some contact with limestone (White 1988). $\mathrm{Ca} / \mathrm{Mg}$ ratios of waters flowing through limestone are often between two and ten, with six a frequent value (White 1988).

All of the springs sampled for this project had $\mathrm{Ca} / \mathrm{Mg}$ molar ratios greater than one (Figure 19). The springs are shown with the approximate locations of geologic formation boundaries (Figure 19). The units are primarily limestone, although many have interbedded dolomite (Table 1). WAT discharges from the Pinesburg Station Formation, a dolomite (Table 1). This spring has the second highest average $\mathrm{Ca} / \mathrm{Mg}$ molar ratio, indicating very little contact with dolomite. BRK and BEL are close to one (Figure 19). Both of these springs emerge from rock units with some associated dolomite, and these localized beds may be providing some magnesium to the waters.

\subsubsection{Partial pressure of $\mathrm{CO}_{2}\left(\mathrm{P}_{\mathrm{CO} 2}\right)$ and saturation index of calcite $\left(\mathrm{SI}_{c}\right)$}

Water samples above saturation with respect to calcite were observed in the spring and summer months in some of the springs sampled (sampling rounds 3 and 5). No precipitates were observed at any of the sites sampled. The springs sampled show 


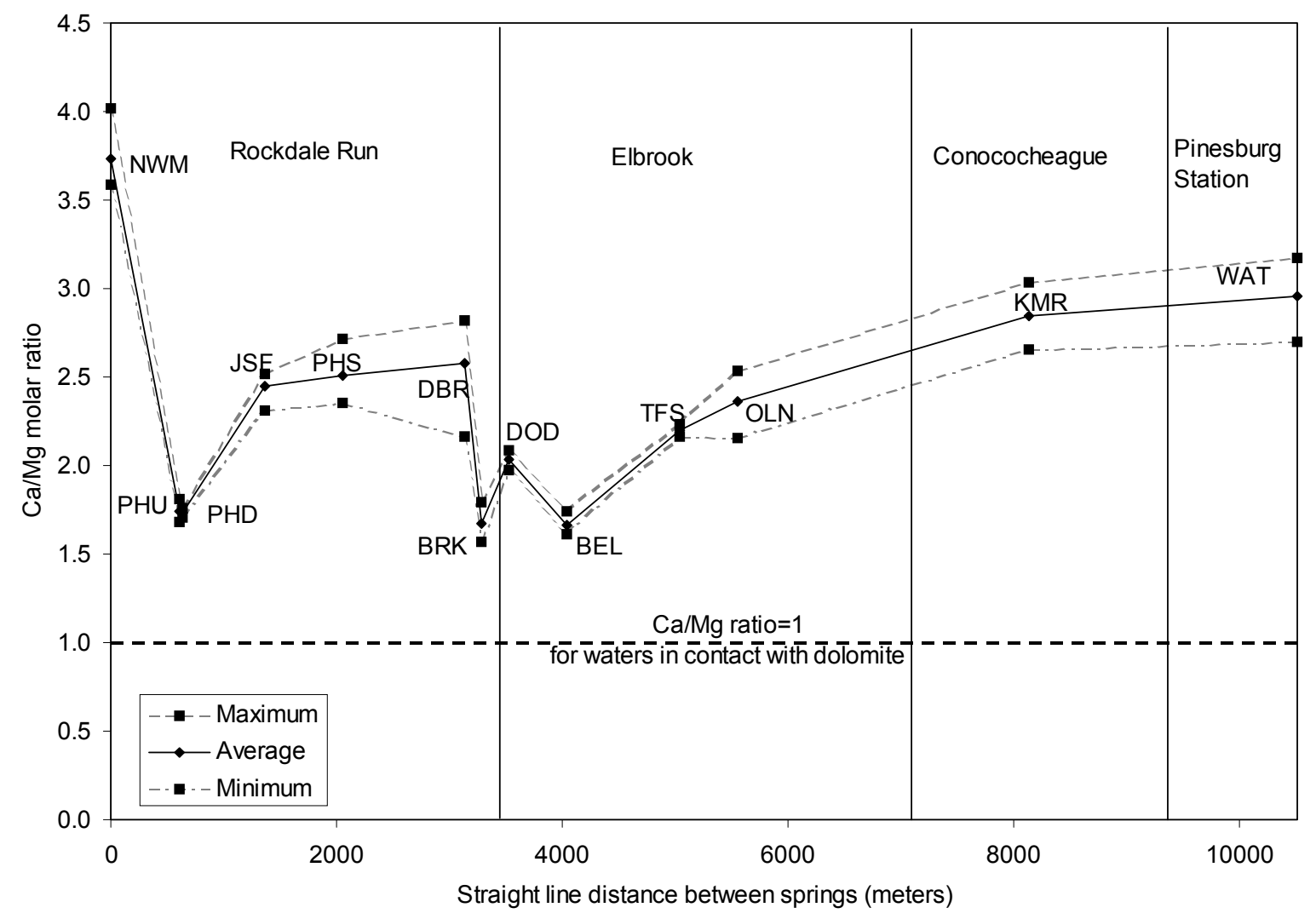

Figure 19: Maximum, average and minimum $\mathrm{Ca} / \mathrm{Mg}$ molar ratio for Tuscarora Creek watershed springs. 


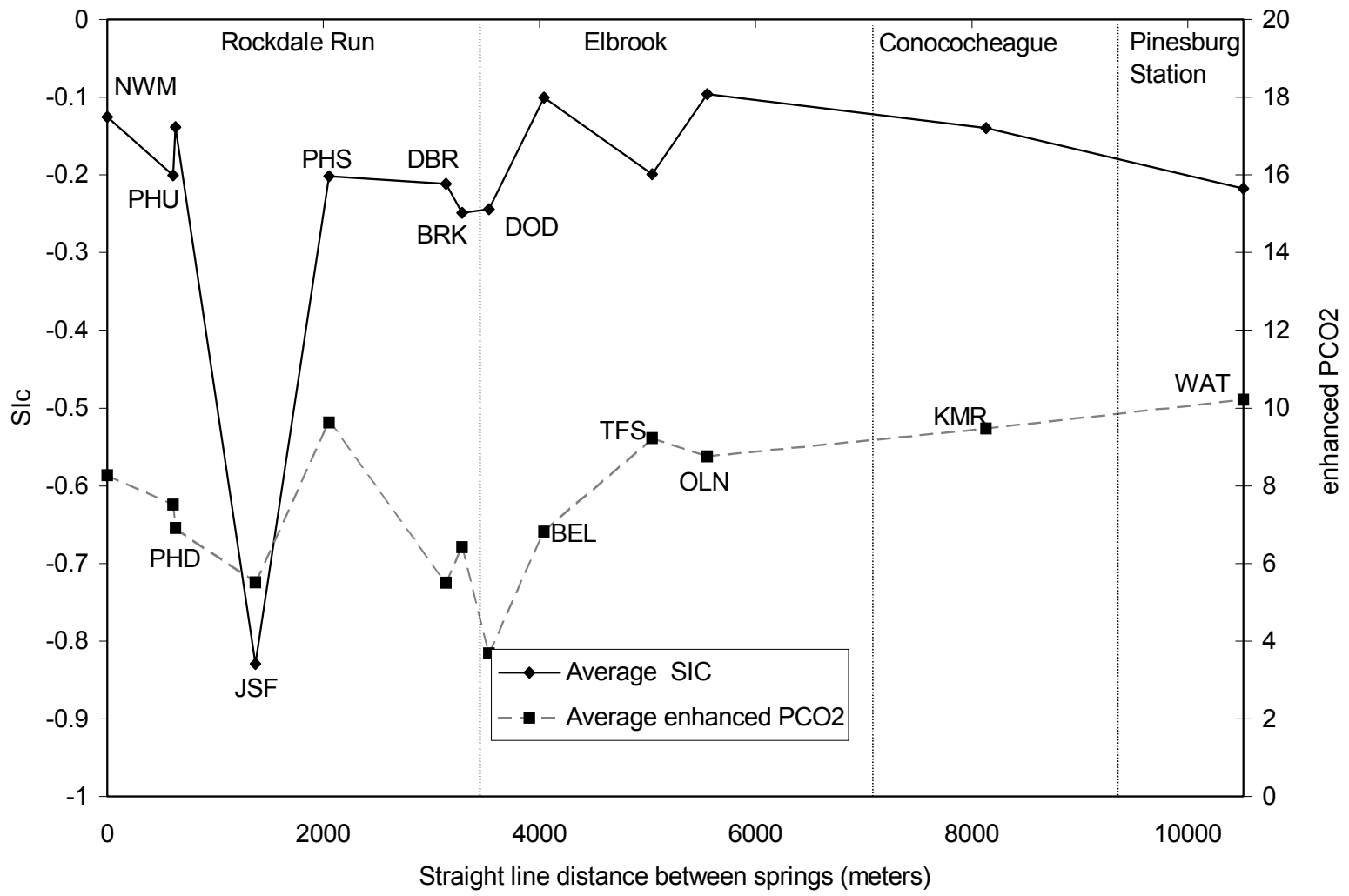

Figure 20: Spatial variability of enhanced $\mathrm{P}_{\mathrm{CO} 2}$ and $\mathrm{SI}_{\mathrm{c}}$ for Tuscarora Creek watershed springs. 
considerable variability in $\mathrm{P}_{\mathrm{CO} 2}$ and $\mathrm{SI}_{\mathrm{c}}$ throughout the watershed (Figure 20). JSF is most highly undersaturated, representing a site in which active dissolution of calcite is occurring (Figure 20). The rest of the sites are closer to equilibrium, with subsequent slower dissolution kinetics.

The $\mathrm{P}_{\mathrm{CO} 2}$ for the sites are well above atmospheric levels, and are similar to soil zone levels (Figure 20). The enhanced $\mathrm{P}_{\mathrm{CO} 2}$ is the average $\mathrm{P}_{\mathrm{CO} 2}$ divided by atmospheric $\mathrm{P}_{\mathrm{CO} 2}\left(10^{-3.5} \mathrm{~atm}\right)$. DOD has the lowest average $\mathrm{P}_{\mathrm{CO} 2}$. This is one of the sites that is lacking a full year's worth of data, so the recorded $\mathrm{P}_{\mathrm{CO} 2}$ is representative of fall and winter values.

\subsubsection{Minor ions}

Ternary diagrams show the relative contribution of the minor anions on a molar basis (Figure 21). The ternary diagram includes only the contribution of the anions, and bicarbonate is not included in the total. In a nitrate-chloride-sulfate diagram, the primary constituents in all of the samples are sulfate and chloride (Figure 21). Nitrate contributes negligibly to the summed total. This trend is consistent for all of the samples collected, including stream data.

\subsubsection{Chloride and sodium}

The presence of dissolved sodium in water samples may be attributed to natural weathering, for example, of igneous rocks rich in feldspars or dissolution of halite or clays (Hem 1989). Both chloride and sodium occur naturally in rainwater at low 


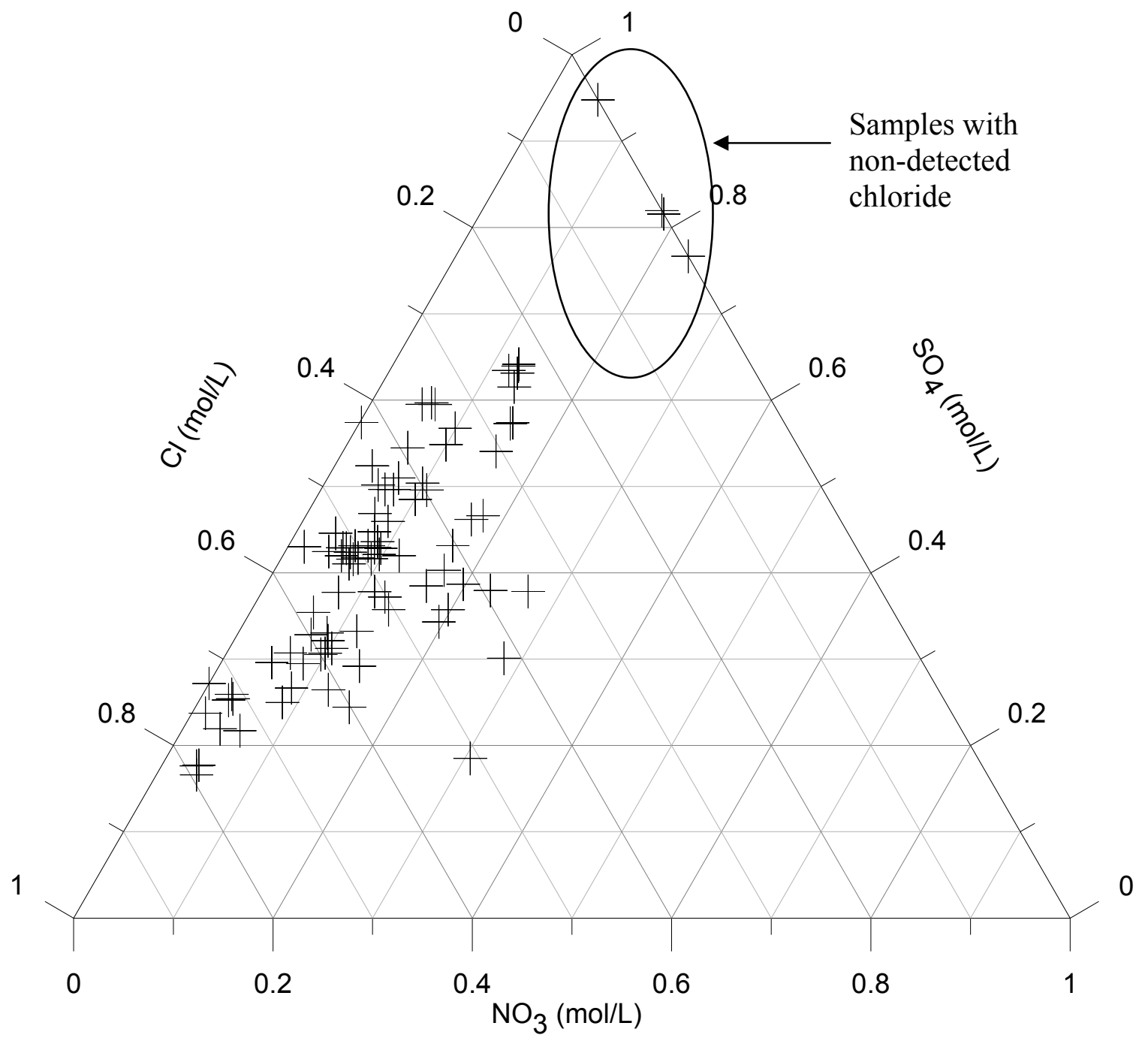

Figure 21: Ternary diagram of chloride, sulfate and nitrate mol/L. 
concentrations of approximately 0.3 and $0.2 \mathrm{mg} / \mathrm{L}$ respectively, for the Eastern Panhandle region (Drever 1997).

WAT has consistently higher chloride and sodium concentrations when compared to the other spring sites for which a complete data set exists (Figures 22, 23). The sites do not show a strong seasonal variability, but there does appear to be a slight increase in the winter of 2003-2004 for some of the sites (Figures 22, 23). There is a peak in September 2004 that may be associated with rainfall.

The springs in the upper watershed are generally lower in average sodium and chloride concentrations than the springs in the lower watershed (Figure 24). JSF has higher chloride and sodium concentrations than the other springs in the upper watershed (Figure 24). The vertical dashed lines indicate the approximate boundary of the different geologic units. BRK, DBR and DOD are located on or near a thrust fault (Figure 4). It may be that waters flowing along the thrust fault are providing a diluting effect.

\subsubsection{Sulfate and nitrate}

The highest concentrations of nitrate are found at KMR and WAT (Figure 25). Both of these sites are located in urban settings. In the upper watershed, higher concentrations are found at PHU, PHD and BRK, although not as high as KMR or WAT

(Figure 25). The presence of nitrate appears at reasonably constant levels throughout the sampling period for the springs for which a complete data set exists (Figure 26). There are significant peaks in concentration for both KMR and WAT. There are no obvious seasonal trends in the data. 


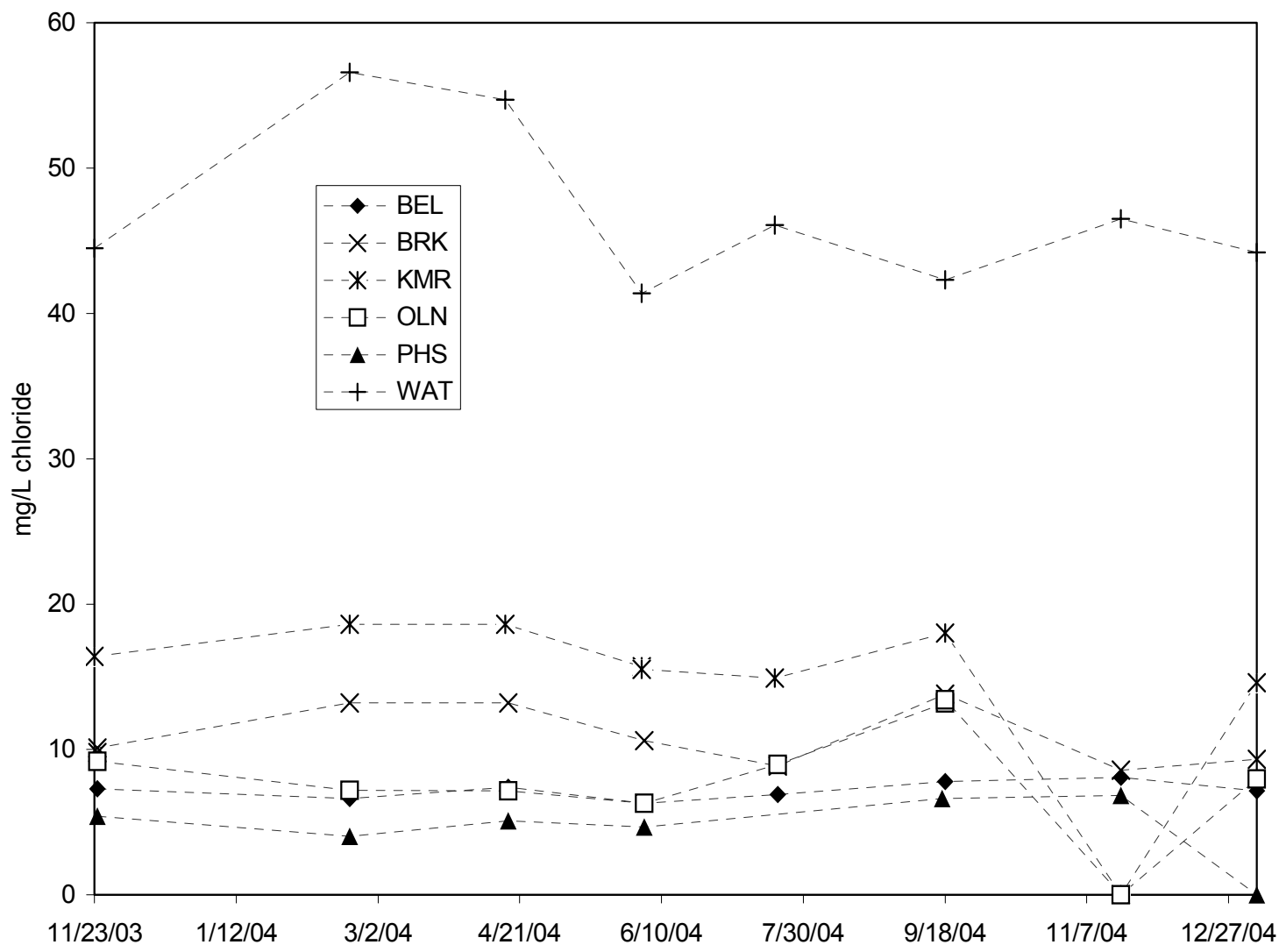

Figure 22: Temporal variability of chloride concentrations for selected Tuscarora Creek watershed springs. 


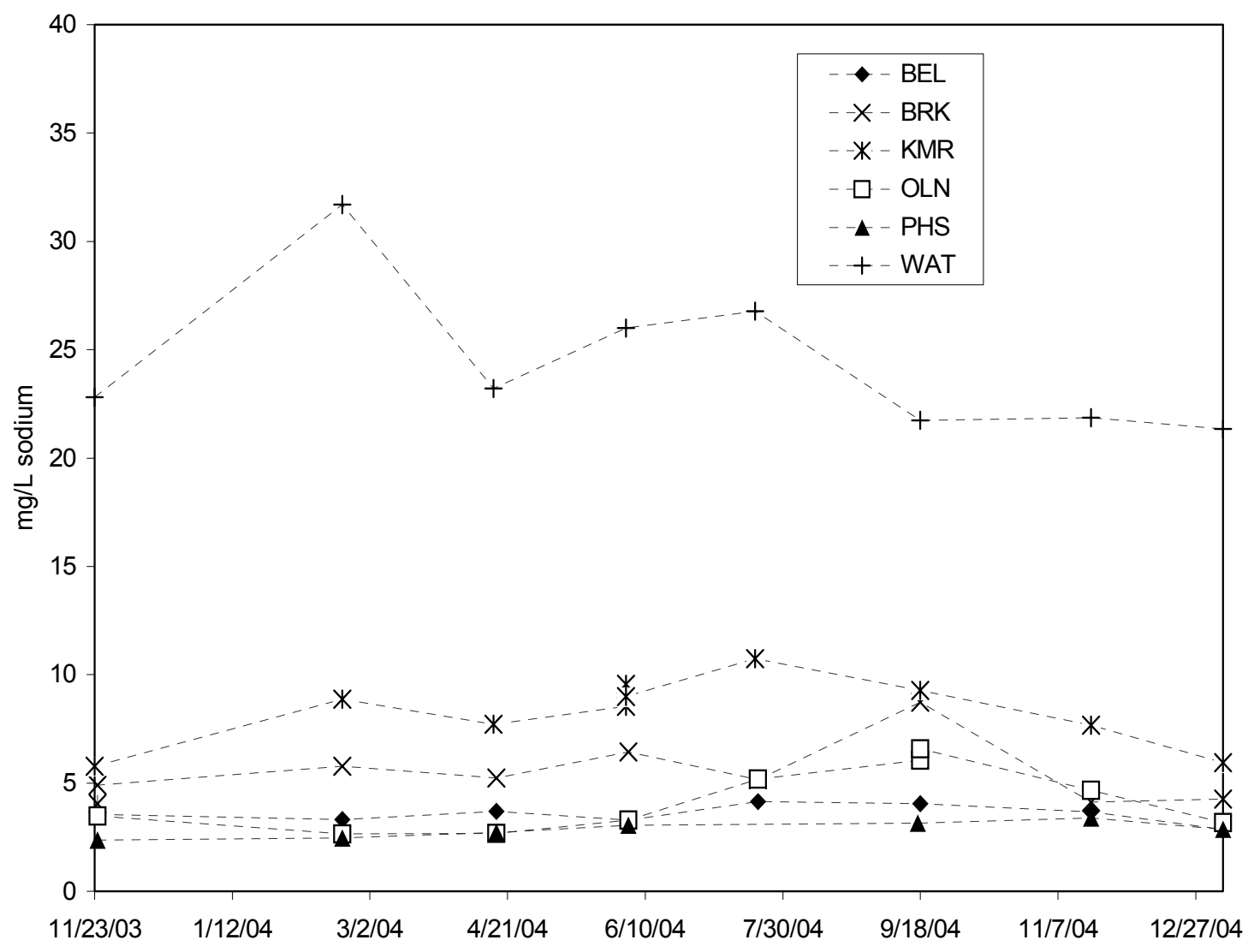

Figure 23: Temporal variability of sodium concentrations for selected Tuscarora Creek watershed springs. 


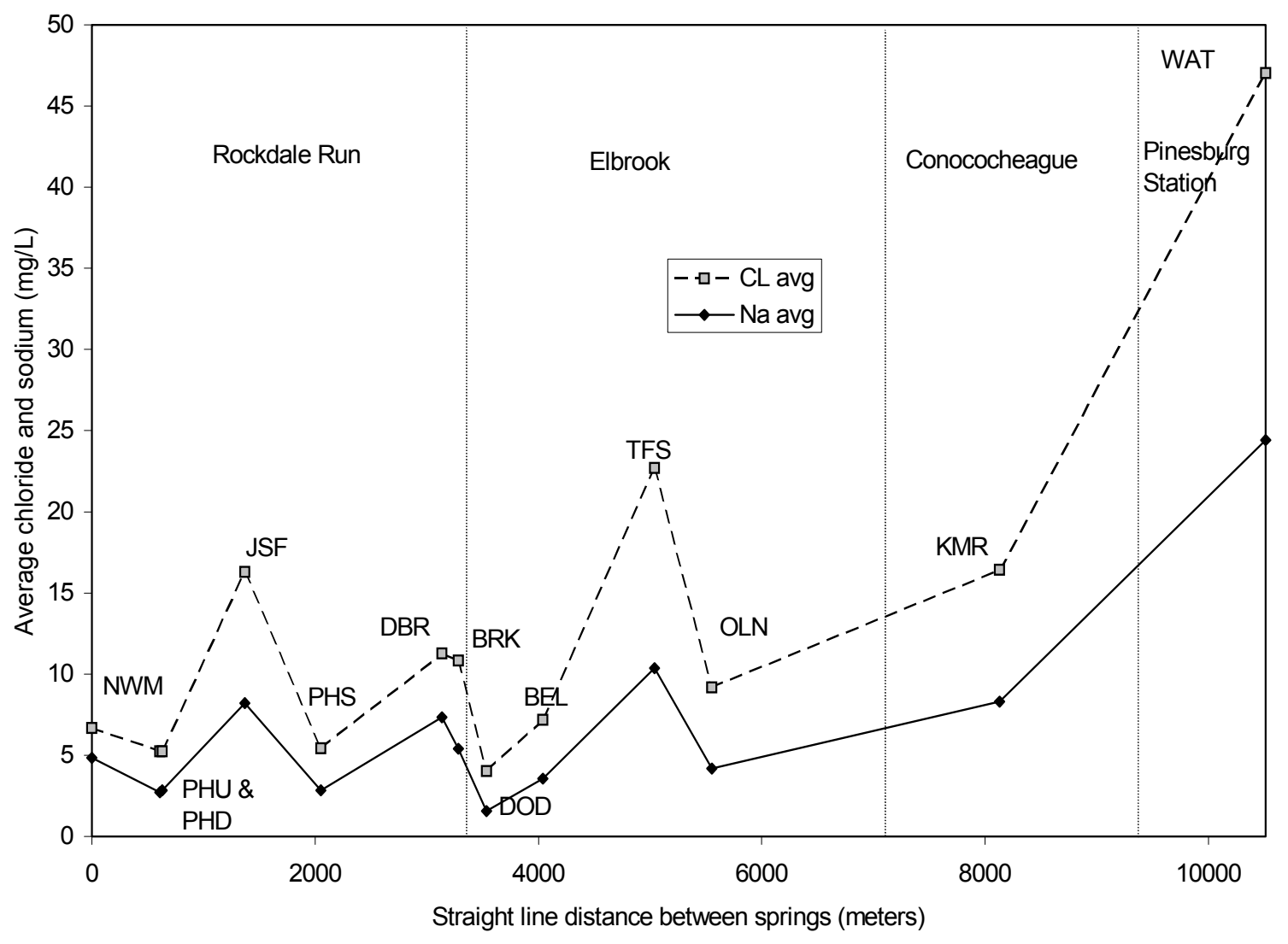

Figure 24: Spatial variability of average chloride and sodium concentrations for Tuscarora Creek watershed springs. 


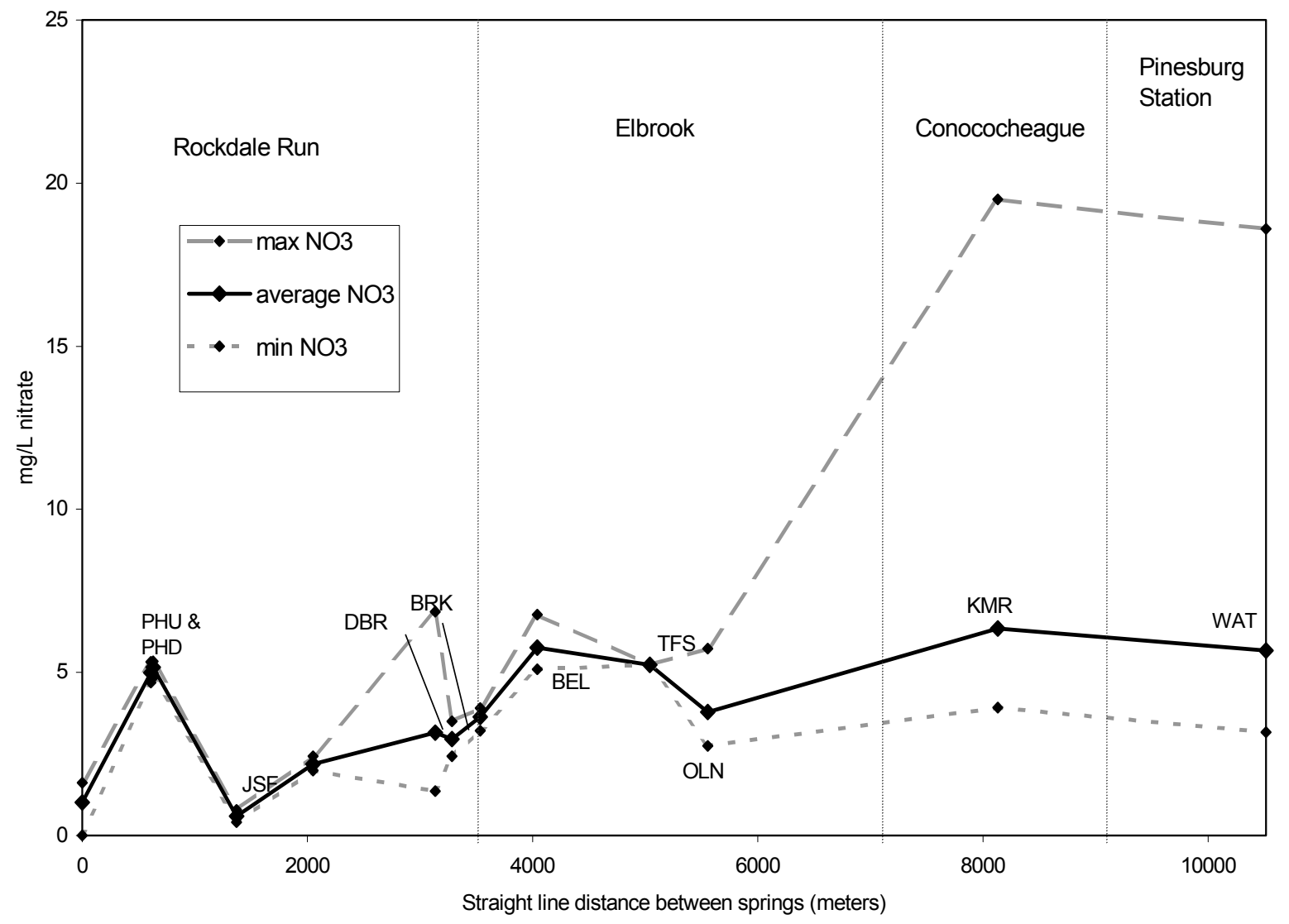

Figure 25: Spatial variability of maximum, average and minimum nitrate concentrations in Tuscarora Creek watershed springs. 


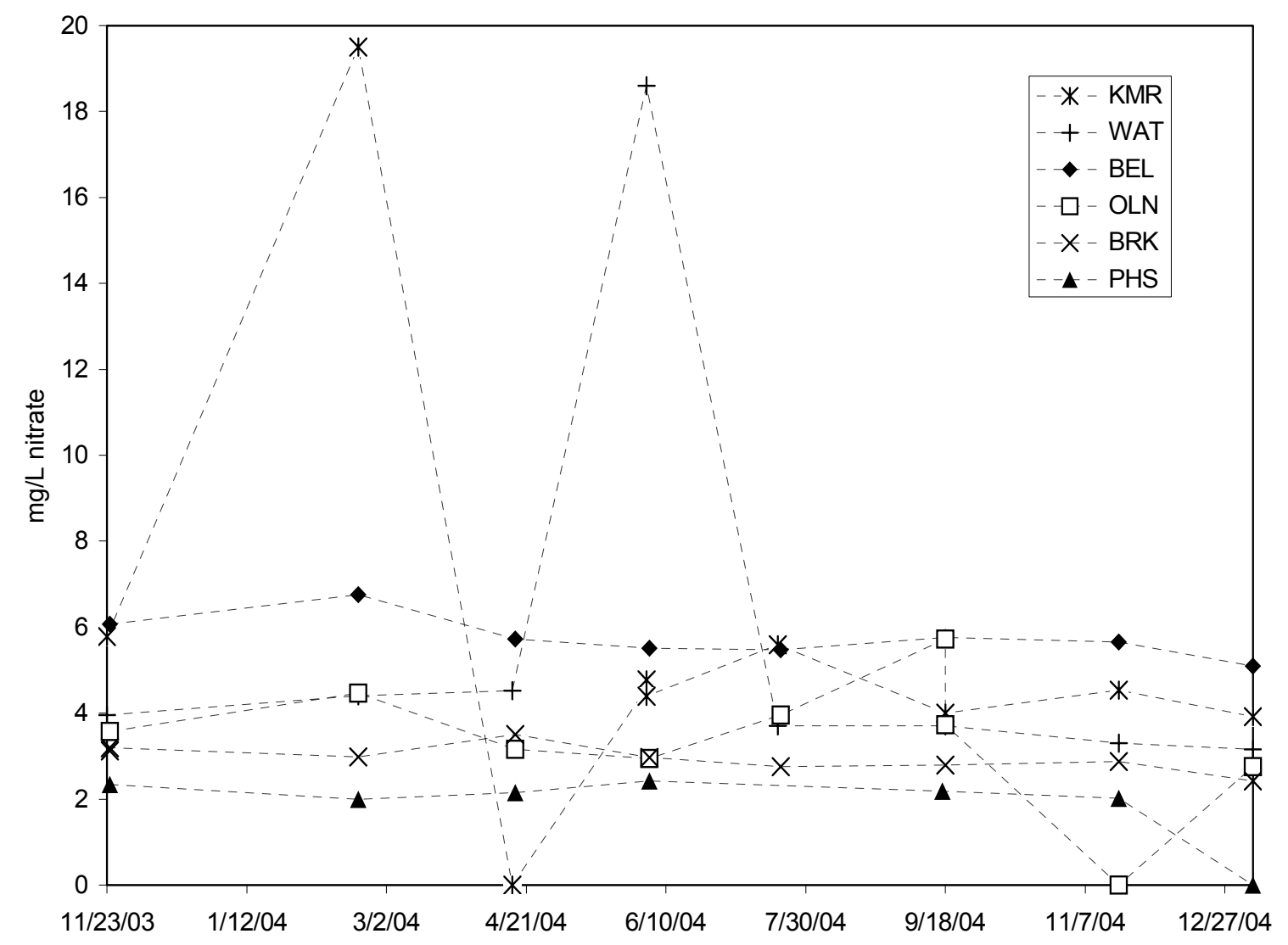

Figure 26: Temporal variability of nitrate for selected Tuscarora Creek watershed springs. 
For sites with enough flow data, the relationship between nitrate and discharge can be examined. BEL has a correlation coefficient of -0.34 with discharge. This suggests that there is some flushing of lower nitrate waters into the system with higher flows. OLN has a statistically insignificant correlation coefficient (-0.09) with discharge. This suggests that there is very little connection between discharge and nitrate. It may be that nitrate is constantly leaching into this system.

WAT has a correlation coefficient of 0.44 between nitrate and discharge. This site may receive higher nitrate concentrations in conjunction with higher flow. This site is located within Martinsburg, and the waters received by this spring during high flow may be the sum of the inputs from the upper watershed.

At the $\mathrm{pH}$ values found in the water samples, sulfate is the dominant sulfur species found in the water (Hem 1989). Sulfur can be naturally occurring or derived from anthropogenic sources. The contribution of sulfur from rainfall is between 2.5 and 3.0 mg/L sulfate (Hem 1989; Drever 1997).

The average sulfate concentration varies through the watershed (Figure 27). Higher concentrations are found at PHU, PHD and BRK (Figure 27). All three of these sites are located within pastureland, however the highest concentrations are found at WAT (Figure 28), which is located in downtown Martinsburg.

The concentration of sulfate appears to increase in the summer and winter of 2004-2005 for the springs for which a complete data set exists (Figure 28). BRK and WAT show consistently higher concentrations than the other sites.

For sites with enough flow data, the relationship between sulfate and discharge can be examined. BEL has a correlation coefficient of -0.29 with discharge. This 


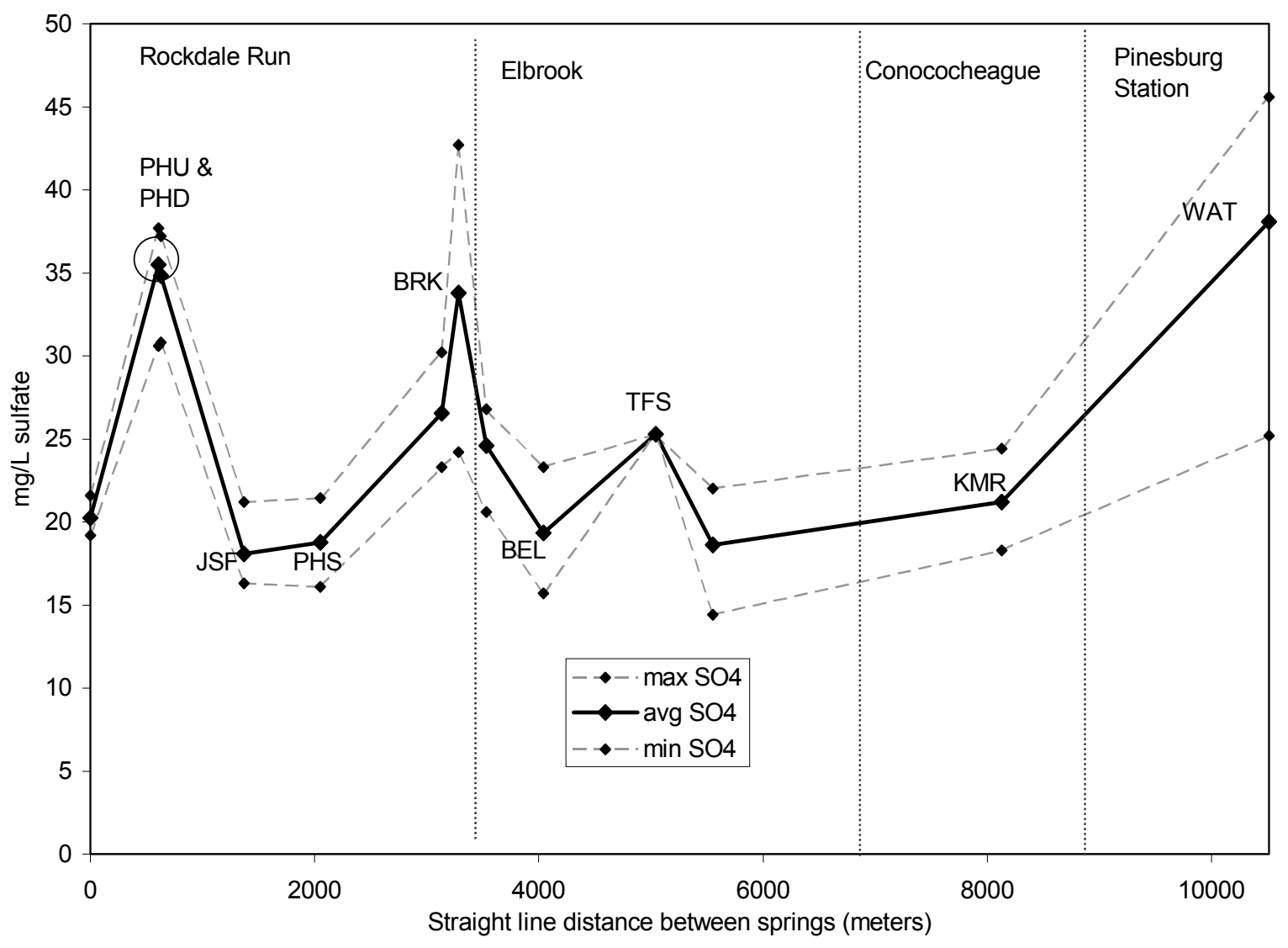

Figure 27: Spatial variability of maximum, average and minimum sulfate concentrations in Tuscarora Creek watershed springs. 


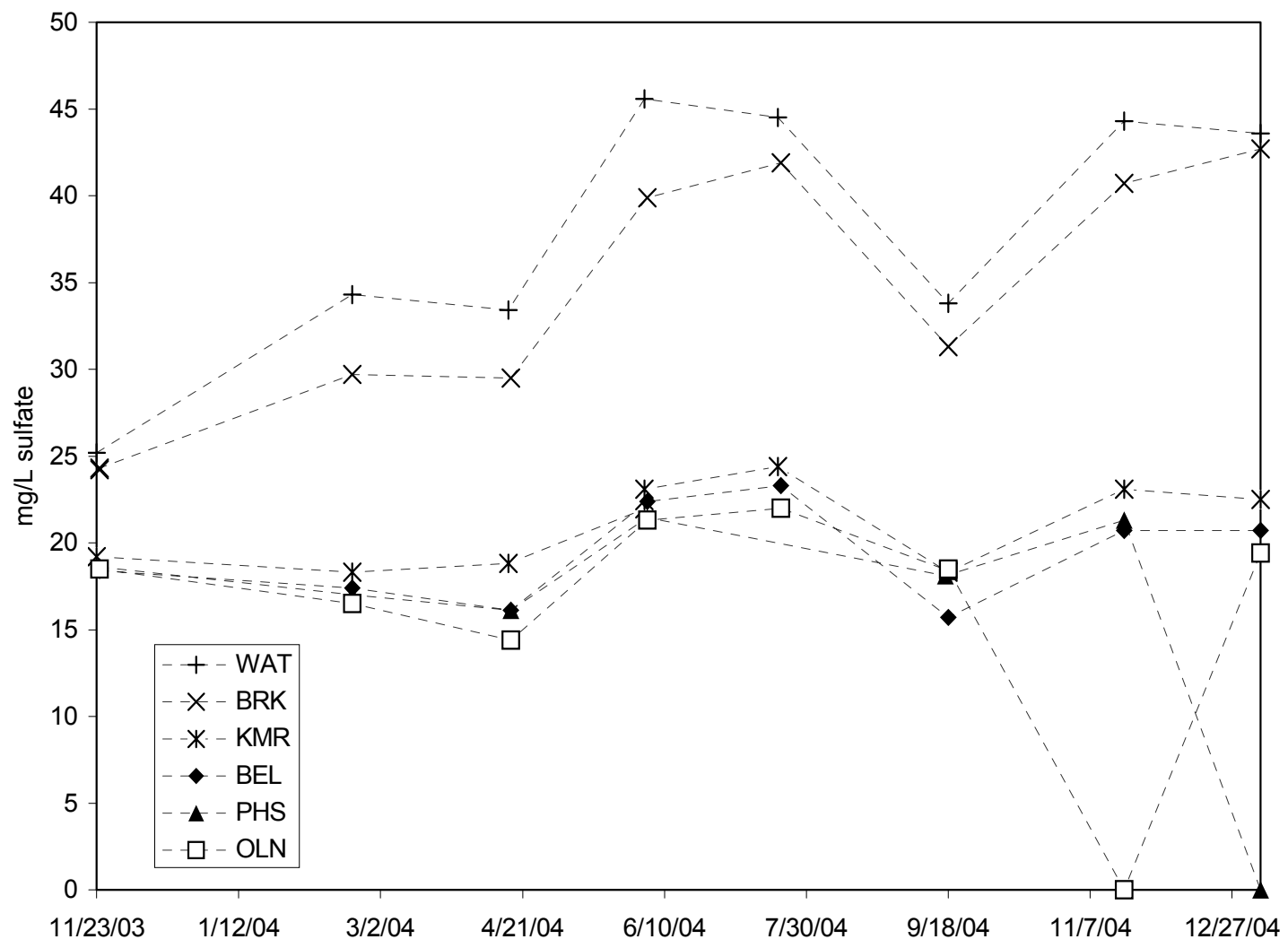

Figure 28: Temporal variability of sulfate for selected Tuscarora Creek watershed springs. 
suggests that there is some dilution with higher flows. OLN has a correlation coefficient of -0.95 with discharge. This suggests a connection between discharge and sulfate. It may be that sulfate is diluted by higher flows. WAT has a correlation coefficient of -0.06 between sulfate and discharge. This site has consistently higher sulfate concentrations than the other sites (Figure 28).

\subsection{Physical parameters}

\subsubsection{Temperature}

The temperature for all of the sites was measured whenever a chemical sample was collected. The highest stream water temperatures are coincident with higher air temperatures in the warmer months (Figure 29).

The springs show a more subdued response to seasonal temperature variation (Figure 30). The sites chosen for comparison are the springs with a full year of chemistry data. The water temperature was taken from within the springhouses for KMR, BEL and OLN. The samples collected from PHS were taken from a PVC pipe and the actual spring location was impossible to sample. It is probable that the water was warmed or cooled as it traveled through the pipe depending on the season. Because of this, this site is excluded from comparison with the other springs. This site was dry during the July 2004 sampling round.

BEL has the lowest temperature $\mathrm{COV}$ and the most consistent water temperature (Figure 30). KMR and OLN both show a seasonal temperature fluctuation. The springhouses do not appear to be stabilizing the water temperature. The consistent temperature at BEL is characteristic of diffuse flow springs (White 1988). 


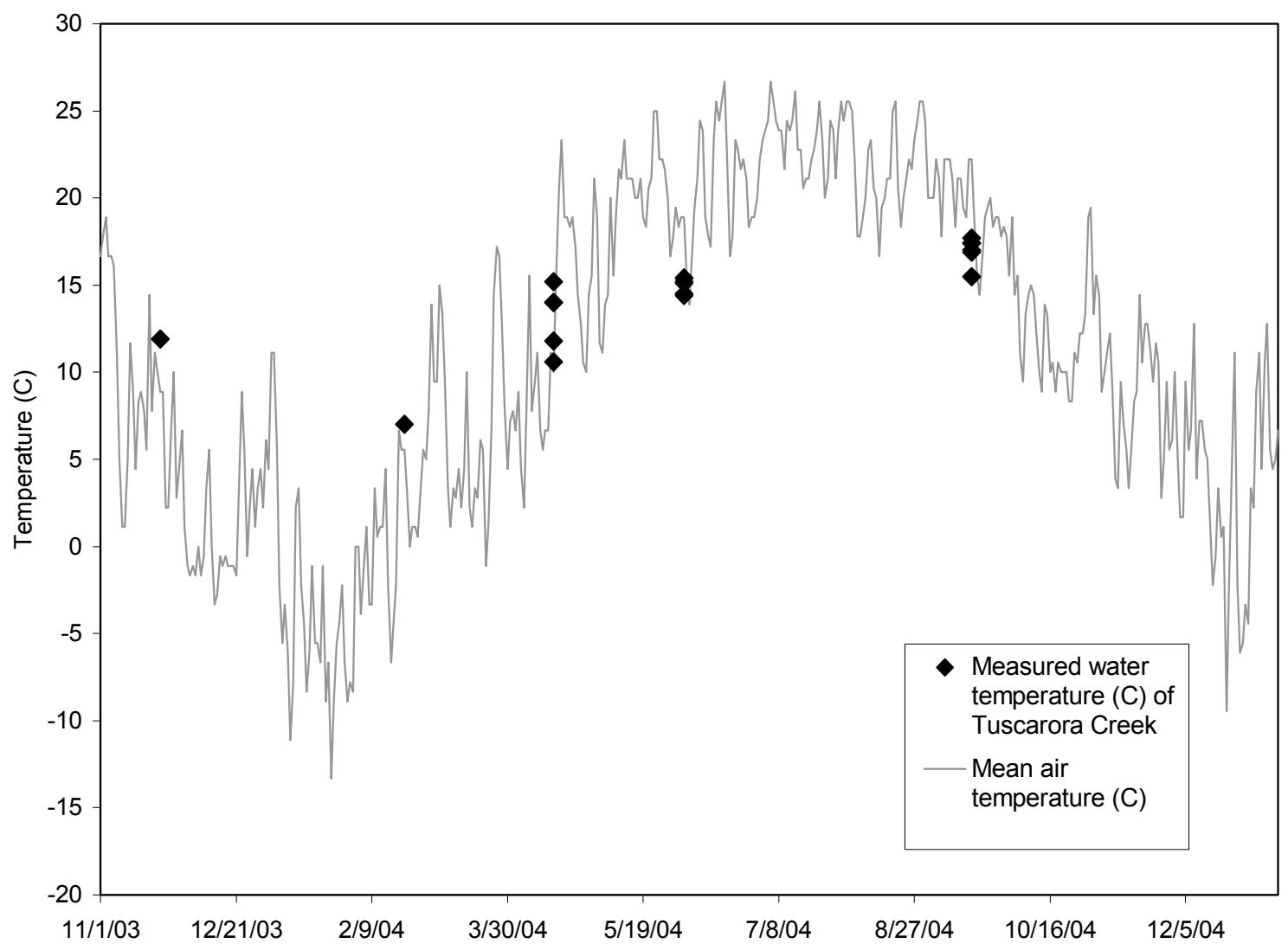

Figure 29: Measured temperature of Tuscarora Creek and mean air temperature as measured at Martinsburg airport (NWS 2005). 


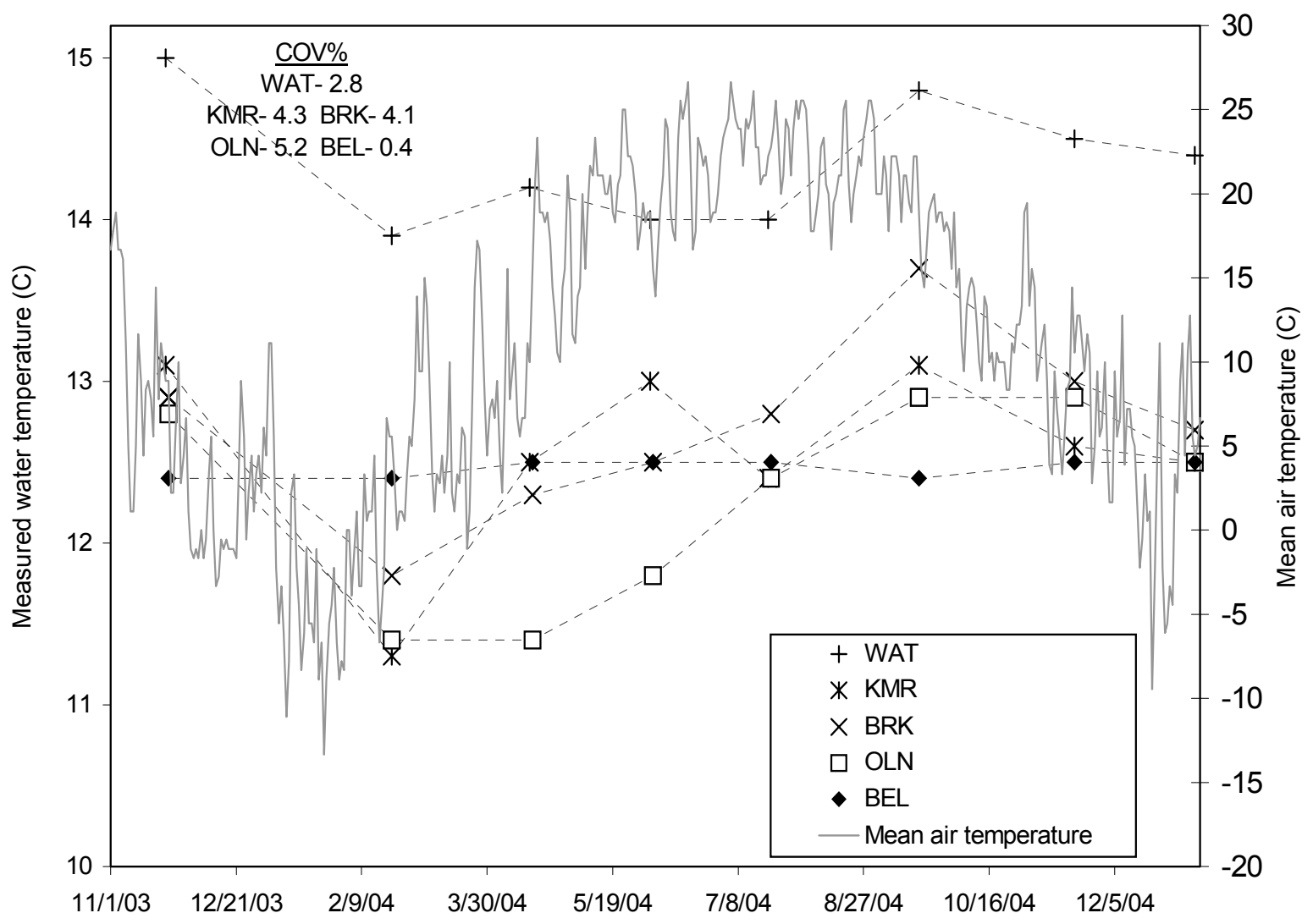

Figure 30: Measured water temperature and mean air temperature as measured at Martinsburg airport (NWS 2005). 
Average air temperature was recorded at the Martinsburg Airport (NWS 2005). The temperature variability is not as apparent as an overall increase or decrease based on air temperature (Figure 30). The highest water temperatures occur in September 2004, although higher air temperatures occurred in June and July. Without frequent data, it is impossible to conclude when the highest water temperatures occurred, or if there is a lag time.

The box and whisker plots for temperature show the range of the data (Figure 31). There is not a complete data set for all of the spring sites, and the incomplete sets may be skewed. PHS has the greatest spread, and BEL has the lowest (Figure 31). WAT has the highest median temperature (Figure 31).

\subsubsection{Flow}

The flow of several of the springs was measured throughout the sampling period (Table 9). KMR has the highest flow, but all flow is diverted to a pipe and the flow could not be measured. BEL has the second highest and WAT has the third highest average flow (Table 8). These two sites also have the highest number of measurements taken. The majority of the flow measurements were taken in conjunction with chemical samples.

For those sites with more than two data points, the flow can be compared to the precipitation (Figure 32). Without more data, it is impossible to determine individual storm responses of the springs. Broad seasonal trends can be observed with the existing data. 


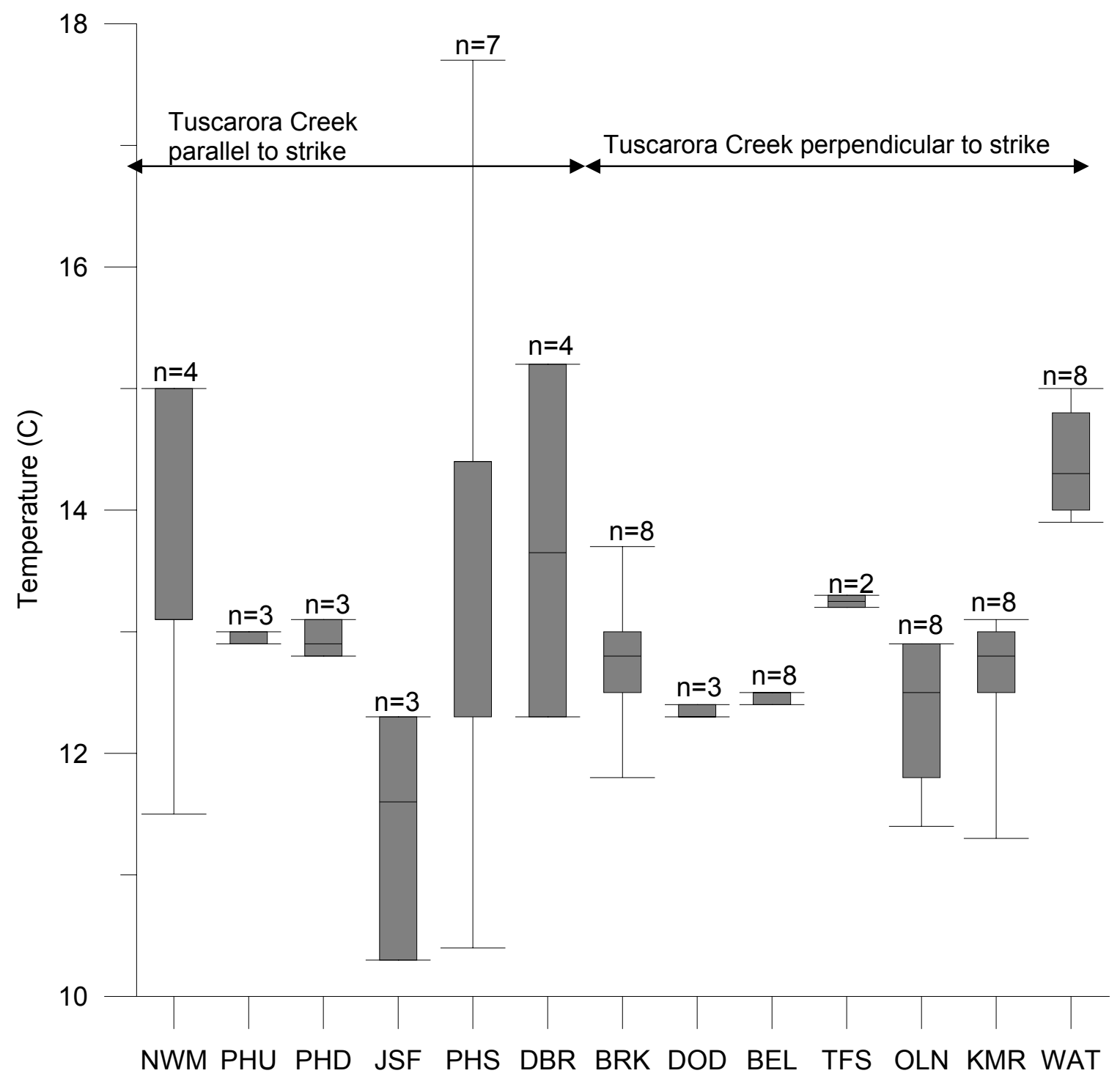

Figure 31: Box and whisker plot of measured spring temperature, $n=$ number of samples. 
OLN has the highest recorded flow for that site in April 2004. The highest recorded flows for BEL are in the spring and summer months, with the noticeable exception of June 2004. WAT also has the highest flows in the summer.

\subsubsection{Seepage run results}

Previous work has indicated that Tuscarora Creek is fed largely by groundwater (Schultz and others 1995). The stream has few, if any, tributaries. The tributary shown on the map was not observed to flow throughout the sampling period. To examine the low flow discharge characteristics of the stream, a series of measurements were taken of the flow at various locations along the stream (Figure 33).

November was chosen as a time of little precipitation, and there was 1.66 inches of precipitation in the twenty days previous to gaging (Drever 1997, NWS 2005). At the same time, the discharge of some of the springs that feed Tuscarora Creek was also measured (Figure 34). The average discharges of OLN and BEL were used, but the flows were not measured on that day.

The difference in the stream discharge and the cumulative spring discharge can be viewed as an estimate of the groundwater supplying the stream. The SC was measured for all of the gaged sites. The SC of Tuscarora Creek was close to, or exceeded, the SC of many of the springs (Figure 35). This suggests that groundwater is supplying flow to Tuscarora Creek. 
Table 9: Average spring discharge.

\begin{tabular}{cccc}
\hline Spring Code & $\begin{array}{c}\text { Average discharge } \\
\text { meters } 3 \text { /second } \\
\text { (gallons/minute) }\end{array}$ & Number of samples & $\begin{array}{c}\text { Range of discharge } \\
\text { (meters } / \text { second) }\end{array}$ \\
\hline KMR & $1.97(2900)^{*}$ & $*$ & $*$ \\
BEL & $0.35(515)$ & 7 & $0.26-0.40$ \\
WAT & $0.25(368)$ & 12 & $0.24-0.36$ \\
NWM & $0.18(265)$ & 2 & $0.09-0.27$ \\
JSF & $0.16(235)$ & 1 & 0.16 \\
DOD & $0.09(132)$ & 1 & 0.09 \\
OLN & $0.06(88)$ & 6 & $0.04-0.09$ \\
DBR & $0.03(44)$ & 2 & $0.03-0.04$ \\
BRK & $0.02(29)$ & 2 & $0.01-0.04$ \\
\hline
\end{tabular}




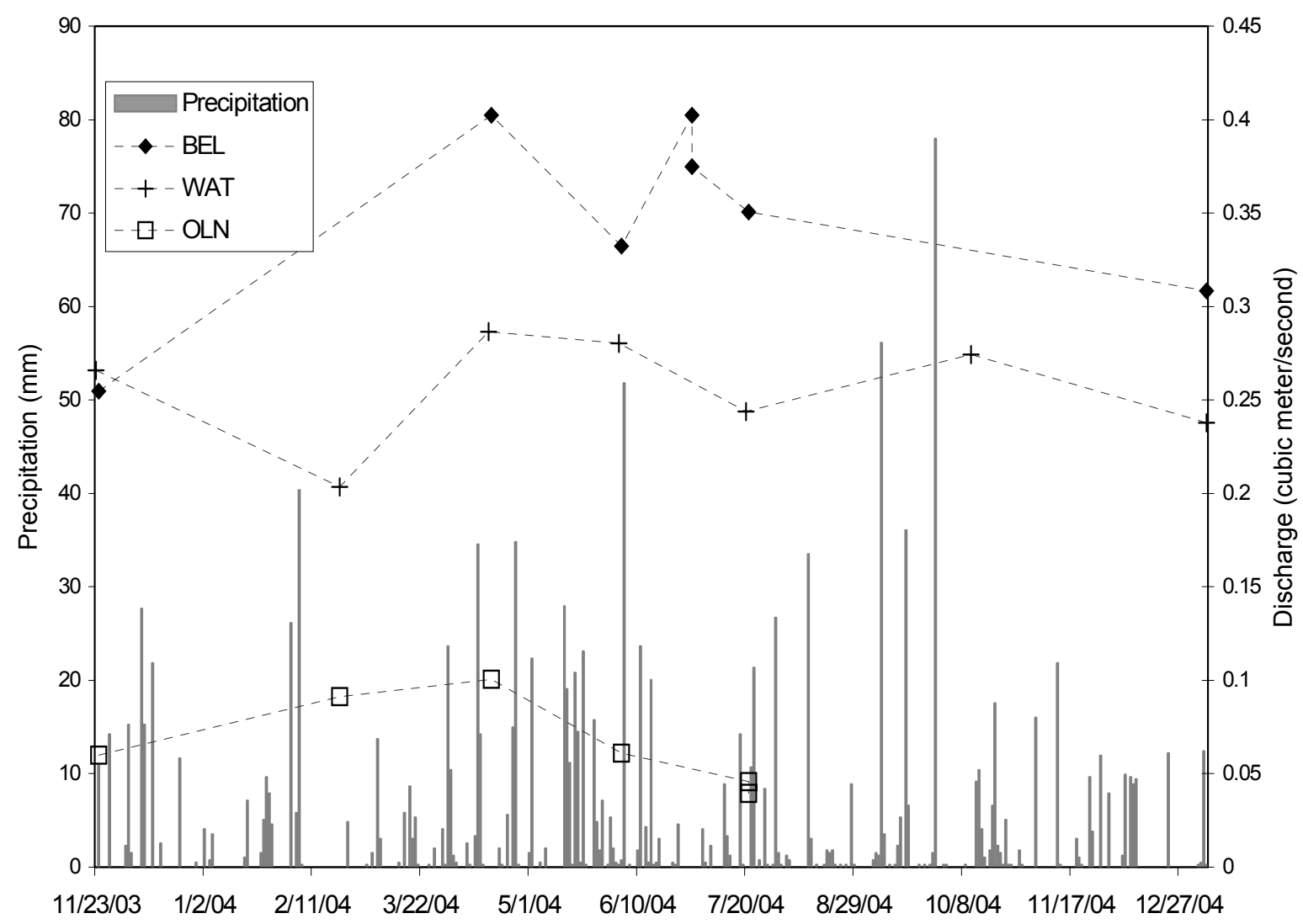

Figure 32: Temporal variability in spring flow for BEL, WAT and OLN compared to average daily precipitation (NWS 2005). 


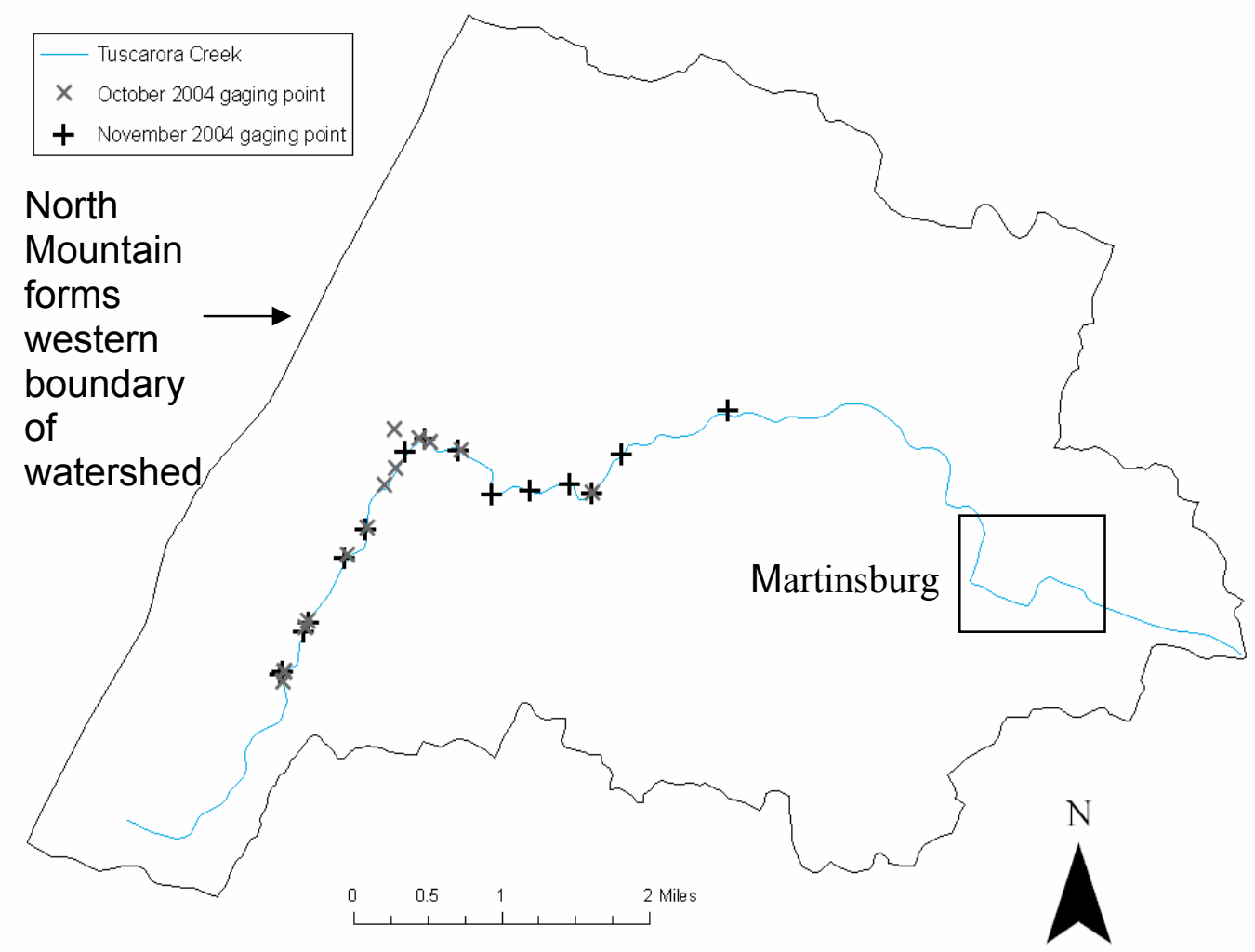

Figure 33: Location of October and November 2004 gaging stations along Tuscarora Creek. 


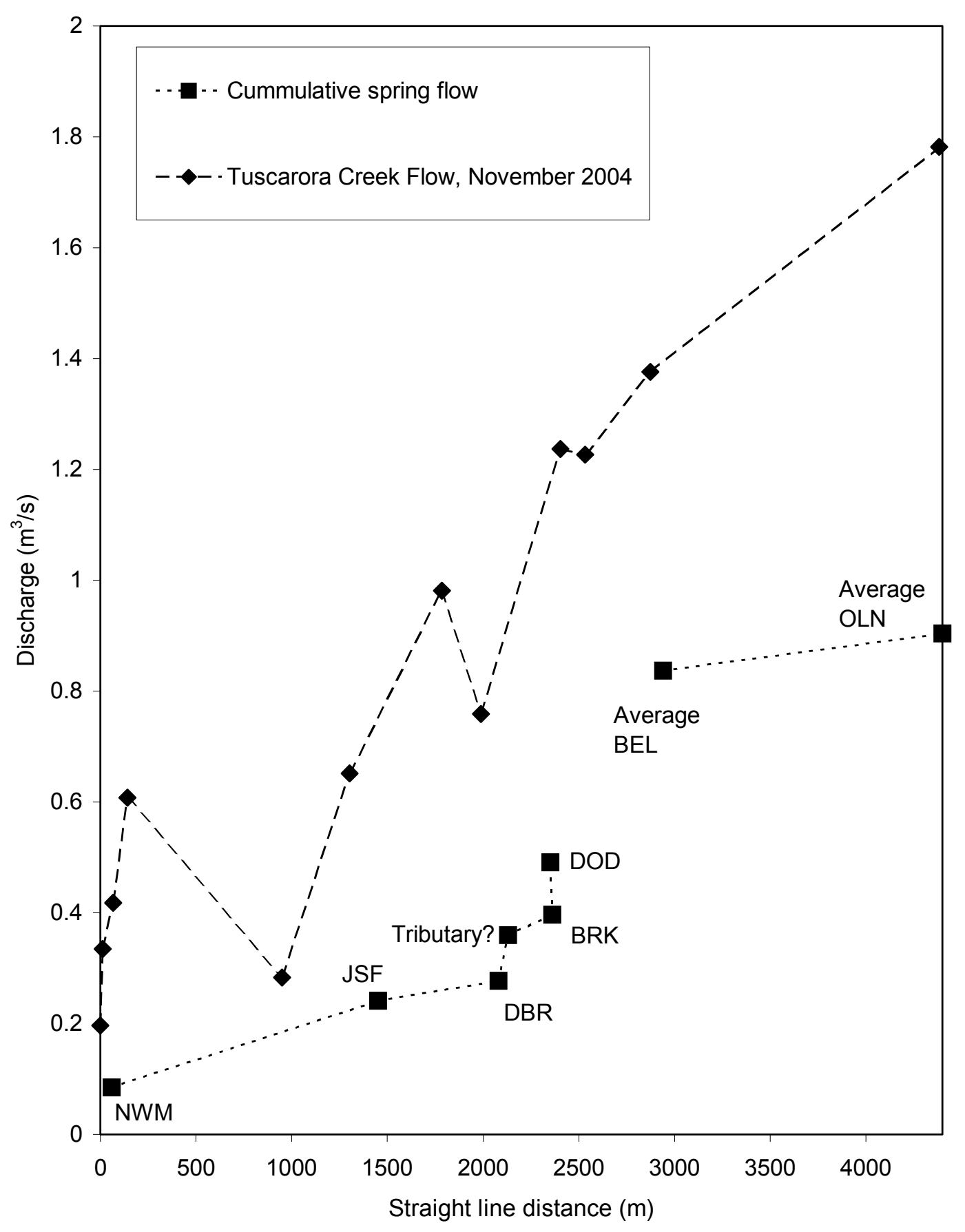

Figure 34: Flow of Tuscarora Creek measured November 20, 2004. 


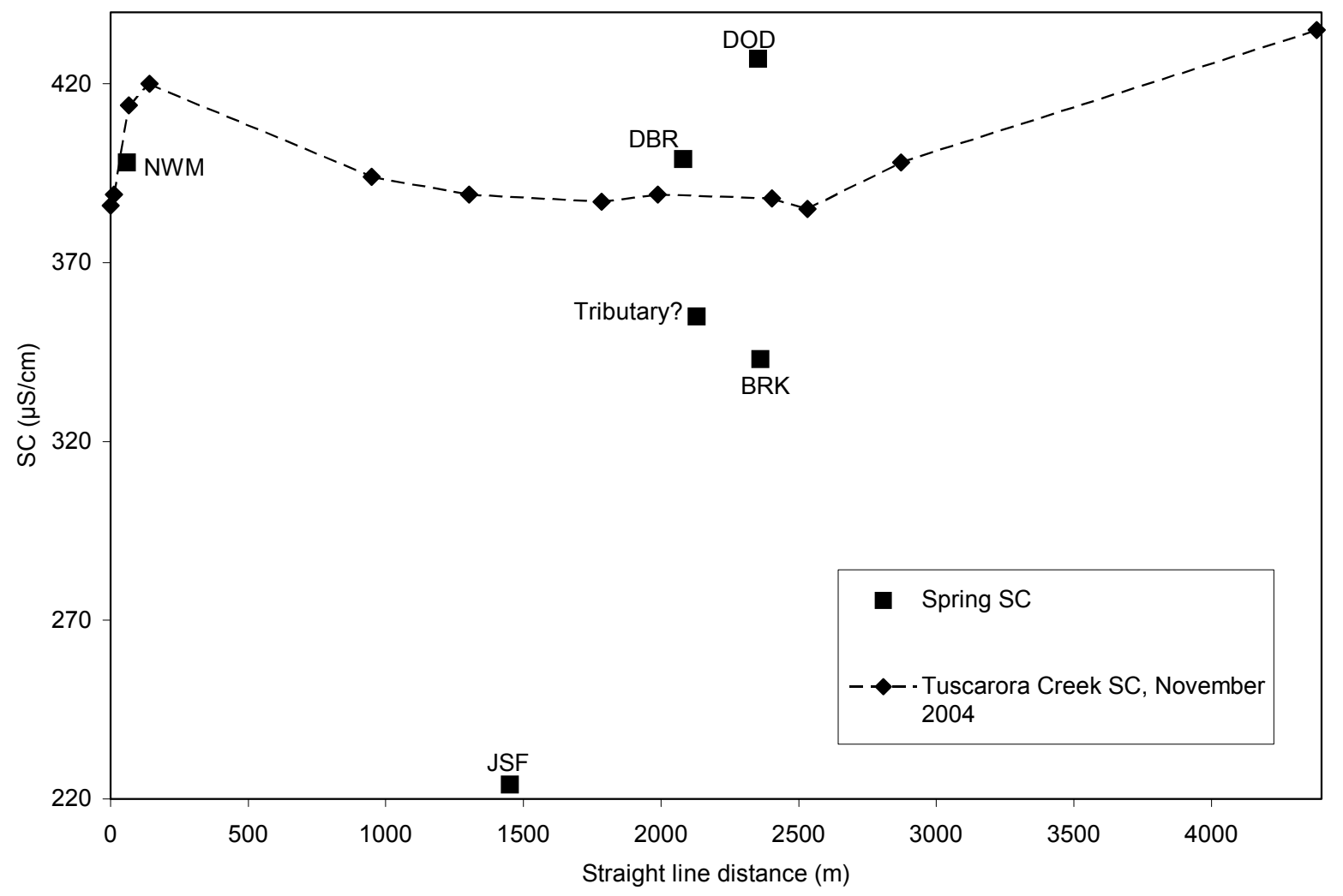

Figure 35: SC of sites along Tuscarora Creek, November 20, 2004. 


\section{Interpretation}

There were several questions posed for this research project:

\section{How does the geochemistry of the springs and Tuscarora Creek itself vary spatially and temporally?}

Spatially, the chemical variability was non-linear longitudinally and appears to be unrelated to underlying geology. NWM, the most upgradient spring sampled, displayed a stronger karst signature than JSF, farther downstream. Even springs in close proximity had distinctly different chemical signatures.

There is more spatial variability between the upper watershed than between the lower watershed springs. The springs in the lower watershed have a stronger karst signature. WAT appears to be more impacted by anthropomorphic influences, both from physical restructuring of the spring as well as from higher concentrations of sodium, chloride, nitrate and sulfate.

JSF is distinctly different from the other springs in the study. This spring has the lowest concentrations of calcium and magnesium. This spring also has higher concentrations of chloride and sodium than the other springs in the upper watershed. The landowner at JSF has reported that the site has to be cleared of sand periodically, and it has been observed to be turbid during storm events. This suggests that this spring has a different flow path than the other springs. The spring may be supplied by sinkholes. The sand could be derived from weathering of the Tuscarora Sandstone, the formation that forms the ridge of North Mountain. 


\section{How does the geology of the region control the springs and Tuscarora Creek?}

Variations in mapped bedrock geology across the watershed do not appear to induce different chemical signatures of the springs. All of the springs are located on rock units comprised of limestone or dolomite.

All of the springs had $\mathrm{Ca} / \mathrm{Mg}$ molar ratios greater than one. PHU, PHD and BRK were closer to one than the other springs located on Rockdale Run. The springs located on this unit were the most variable. There were also more springs located on this unit than on the others. WAT is located on the Pinesburg Station Formation, a dolomite. However, the $\mathrm{Ca} / \mathrm{Mg}$ molar ratio suggests that the water flows primarily through limestone.

The structure of the area appears to have more of an impact on the springs than the different lithologic units. The springs in the upper watershed are close to a thrust fault, as is Tuscarora Creek. The previously calculated transmissivity was higher in the upper watershed (Schultz and others 1995). This suggests that groundwater movement is facilitated by the thrust fault, and that the greater chemical variability of the upper watershed may be due in part to this proximity to the thrust fault. Fractures throughout the watershed may also help to determine spring location.

The synclinal structure of the rocks may facilitate water movement. The lesser folds within this structure probably account for the high $\mathrm{Ca} / \mathrm{Mg}$ molar ratio of WAT as the waters interact with rocks of different lithologies. 


\section{How is the chemical variability of the springs controlled by land use in the watershed?}

Anthropogenic sources, such as road salting, leaky sewer/septic systems and leaking water main supplys, can contribute to elevated chloride and sodium in water (Hem 1989). By plotting the molar concentration of chloride and sodium, the constituents can be compared on a 1:1 basis (Figure 36). The chloride and sodium occur in almost equal ratios for most samples, suggesting a salt source for both, possibly from road salting or discharge from water softeners into septic or sewer systems (Figure 36). The concentration of chloride and sodium is relatively consistent through time (Figures $22,24)$.

WAT has consistently higher levels of chloride and sodium as compared to the other sites (Figure 36). Chloride occurs in higher concentrations than sodium. This spring is located in downtown Martinsburg and these elevated levels are probably due to anthropogenic influences, such as leaky water supply lines.

The samples collected from Tuscarora Creek are similar to the spring samples, suggesting the same, or similar, sources are affecting both the springs and the stream (Figure 36). The springs contribute to the flow of the stream, and so some of the chloride and sodium is undoubtedly derived from the spring contribution. If the springs were the sole contributors of chloride and sodium, it would be expected that the concentrations would be diluted in the stream samples. 


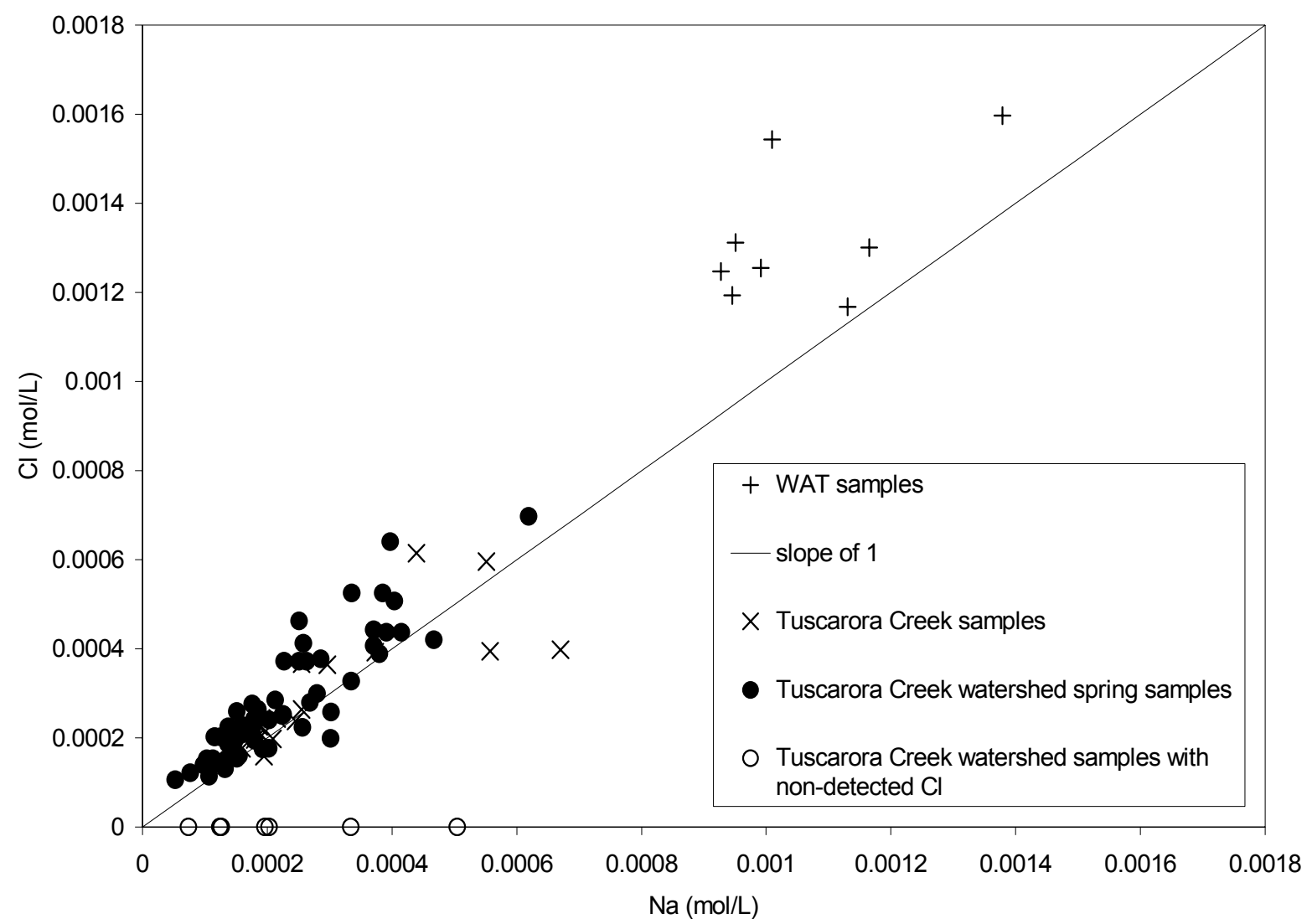

Figure 36: Molar concentrations of chloride and sodium for Tuscarora Creek watershed spring and stream samples. 
The correlation coefficient of sodium and chloride molar concentration is 0.93 . This calculation used all samples, including the stream data and outliers from sampling rounds 7 and 8 . There is a strong linear correlation between sodium and chloride with a slope near one, suggesting that the source is common, contributing both chloride and sodium in equal parts. It is reasonable to assume that the sodium and chloride are derived from anthropogenic sources.

If the presence of chloride and sodium is associated with road salts, the concentrations may depend on rainfall. However, there is probably an initial flushing of the constituents from soils and then a subsequent dilution with more precipitation. Without extensive precipitation and discharge data for these sites, this is speculation.

If the source were road salting, the only deposition would be in the winter months. It is probable that each year's salting does not flush through the system, but instead there are areas of accumulation as well as of flushing throughout the watershed. A study of a watershed in Canada found that less than half of the road salts were flushed out of the watershed yearly, and predicted that a steady state would be achieved with soil storage and subsequent groundwater impact (Howard and Haynes 1997).

The majority of the springs sampled are located within 100 meters of a road, so it is reasonable to assume that road salting, or input from household sources (septic, water softeners) would affect the sites. However, the only site that shows a strong seasonal trend is WAT.

Nitrate is generally taken up by plants, and when mobile in an aqueous phase, is present in excess (Drever 1997). Nitrate can originate from agriculture by-products, such 
as fertilizer or animal waste (White 1988; Drever 1997). As of 1993-1994, 35.6\% of Tuscarora Creek watershed was pasture or grassland.

The nitrate concentrations found in the stream samples are similar, but generally lower, than the spring samples. Three of the upper watershed springs (PHU, PHD and BRK) are located within pastureland. However, possible quality problems with the nitrate data may limit these interpretations.

WAT is located in Martinsburg, WV and exhibits some of the problems with quantifying an urban spring. The original spring discharge point has been destroyed, and the water now flows from a pipe. The spring has a strong karst signal, but there may be other waters mixing with the flow, including storm waters. However, the high calcium concentrations of the water sampled suggests little dilution from storm water.

\section{To what extent does groundwater contribute flow to Tuscarora Creek?}

The result of the low-flow seepage run suggests that Tuscarora Creek is supplied largely by direct influx of groundwater. The relative contribution of direct groundwater flow and spring contribution can be estimated from the seepage run data (Figure 37). This estimate assumes that there are no appreciable tributaries on Tuscarora Creek, and so the only flow will be derived from springs or direct groundwater recharge. The estimated direct groundwater component of Tuscarora Creek flow ranges from $74 \%$ at the most upstream site to $53 \%$ at the most downstream site gaged.

This calculation is based an exponential equation fit to the stream discharge and cumulative spring discharge data collected in November 2004. It only includes the upper watershed and the lower watershed to upstream of OLN due to the limitations of 


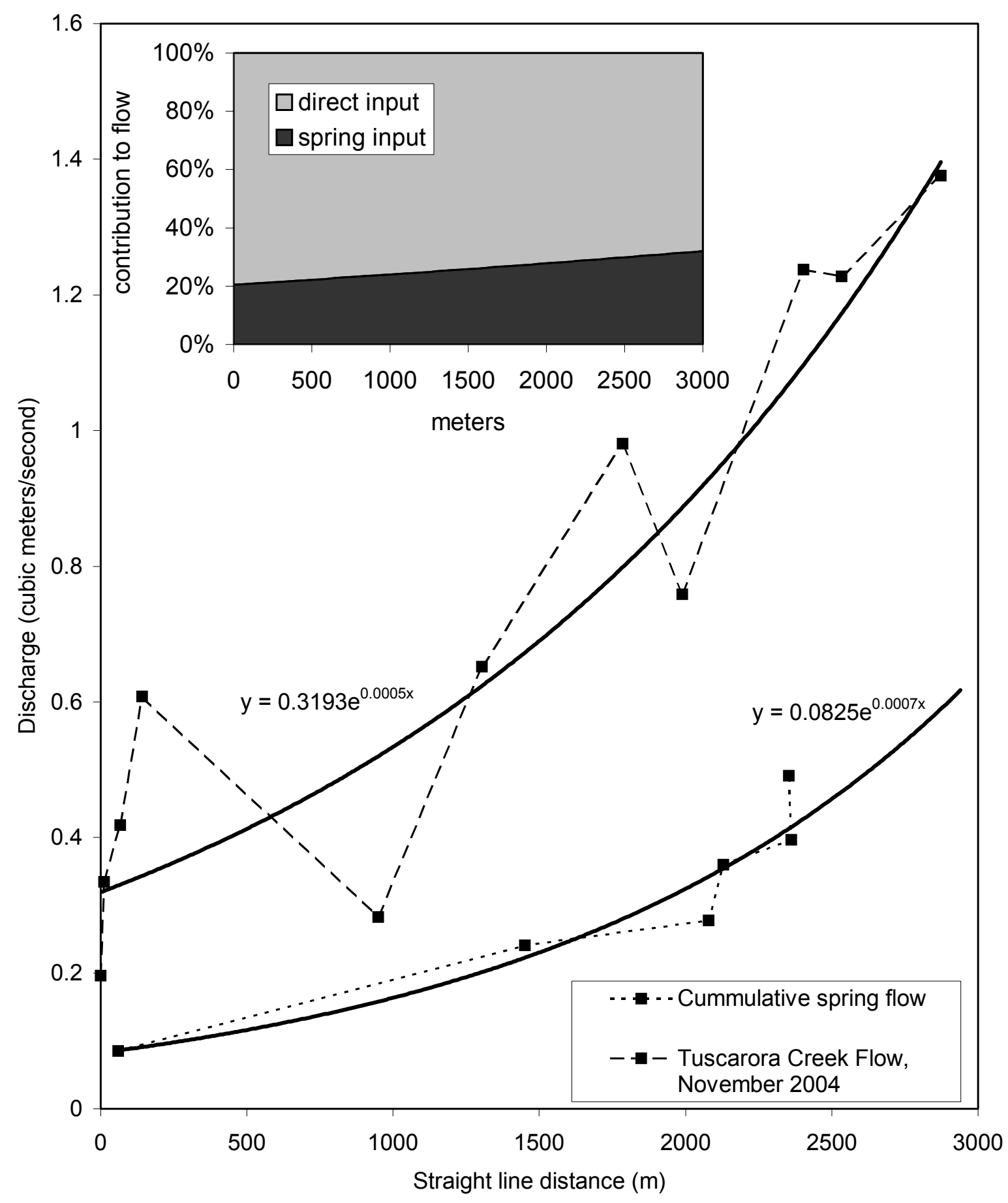

Figure 37: Estimated contribution to flow in Tuscarora Creek from springs and direct groundwater discharge. Bold line =best fit to data using exponential equation. 
available data. There are insufficient data to determine the relationship further

downstream. It is likely to vary seasonally, however, the estimate provides strong evidence that Tuscarora Creek receives most of its flow from groundwater. The similarity of SC in the springs and stream, and the lack of perennial tributaries, further supports this conclusion.

\section{How does a small-scale study fit larger models of karst systems?}

$\mathrm{SI}_{\mathrm{c}}$ can be shown to increase between springs and stream as a result of $\mathrm{CO}_{2}$ degassing (White 1997). The stream samples from this study cluster away from the majority of the spring samples, but the two groups trend along the $\mathrm{P}_{\mathrm{CO} 2}$ degassing pathways (Figure 38). These lines illustrate the inverse relationship between $\mathrm{P}_{\mathrm{CO} 2}$ and $\mathrm{SI}_{\mathrm{c}}$ and show that supersaturation with respect to calcite is driven by a loss of $\mathrm{CO}_{2}$ (Jacobson and Langmuir 1970; White 1997). This is an indication that the water supplying the stream is derived from groundwater.

The dashed horizontal lines (Figure 38) represent the approximate kinetic thresholds for precipitation and dissolution of calcite (White 1997). Above and below these thresholds, more rapid precipitation (for oversaturated water) or dissolution of calcite (for undersaturated waters) occurs (White 1997). The lines $\mathrm{CO}_{2}$ degassing lines are continuous because they are calculated from an equation (White 1997) relating the two variables. These lines represent the path a water sample would take as $\mathrm{P}_{\mathrm{CO} 2}$ decreases, and the $\mathrm{SI}_{\mathrm{c}}$ increases. Degassing, and subsequent changes in $\mathrm{SI}_{\mathrm{c}}$, is rapid. Note that the data cluster into two groups and are not continuous. 


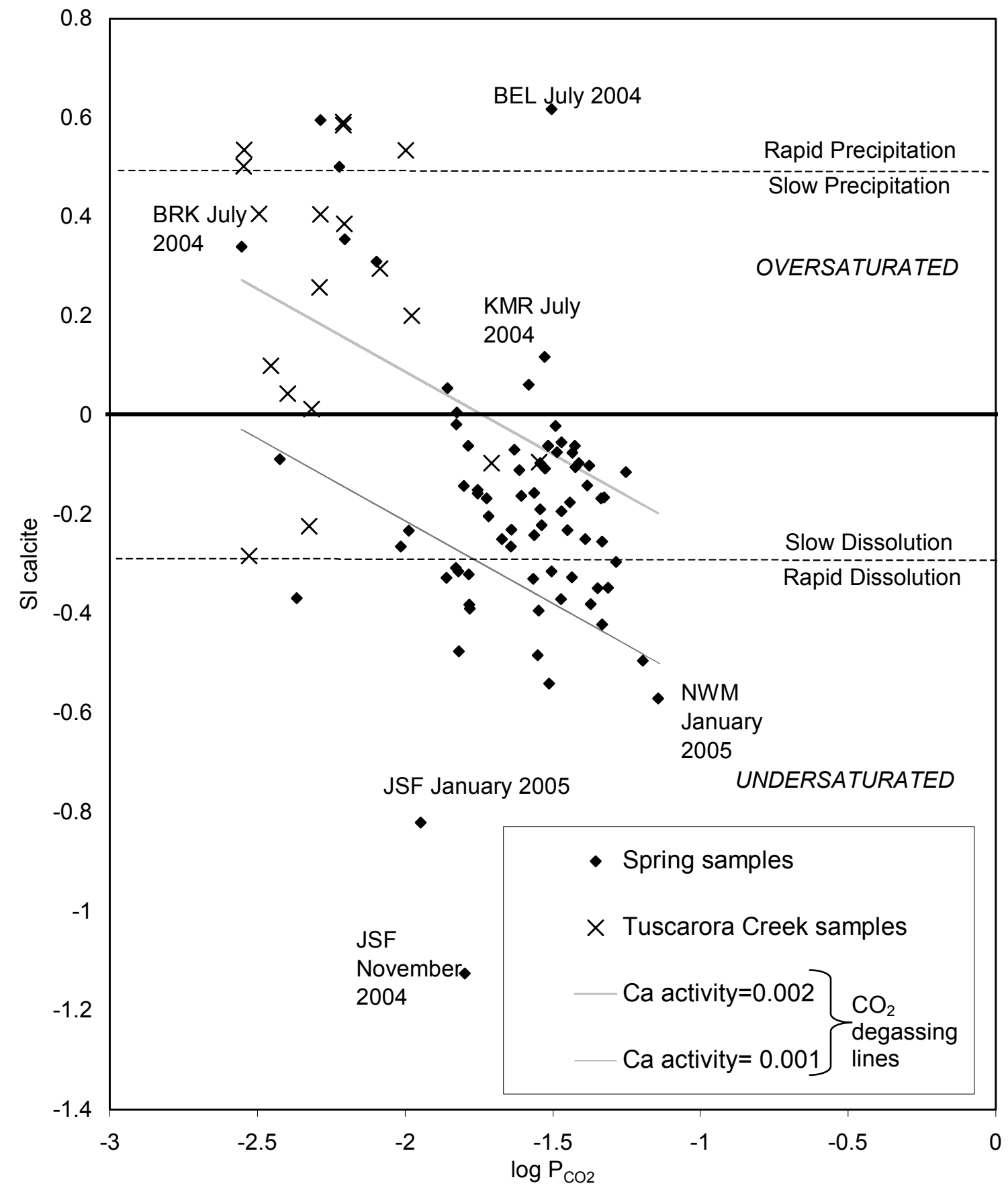

Figure 38: $\log \mathrm{P}_{\mathrm{CO} 2}$ versus $\mathrm{SI}_{\mathrm{c}}$ for Tuscarora Creek watershed water samples, modified from White 1997. 
There appears to be a broad trend in seasonal variability (Figure 38). Oversaturation of spring samples occurs in the spring and summer months (sampling (rounds 3 and 5). JSF is always undersaturated, but some of the springs are more undersaturated in the winter months (sampling round 7 and 8).

Springs within Appalachian karst valleys similar to Tuscarora Creek watershed have been characterized on the basis of variations of $\mathrm{P}_{\mathrm{CO} 2}$ and $\mathrm{SI}_{\mathrm{c}}$ (Drake and Harmon 1973). Significant differences were found between diverse waters, including recharge from allogenic recharge and seepage recharge (Drake and Harmon 1973). Further differentiation was made for springs, categorizing samples as conduit or diffuse (Drake and Harmon 1973).

The average values for each type of water that were differentiated were compared with the average values for each spring and stream sample on Tuscarora Creek watershed (Figure 39). Only one of the springs, BRK, on Tuscarora Creek watershed falls within the schematic zone of diffuse springs (Figure 39). Most of the other samples, stream and spring, fall within the Drake and Harmon (1973) schematic characterization of waters from wells (Figure 39). These sites are characterized by $\mathrm{SI}_{\mathrm{C}}$ close to saturation and higher $\mathrm{P}_{\mathrm{CO} 2}$ than other types. The waters identified as well water are derived from seepage recharge and have a long residence time (Drake and Harmon 1973).These sites can be considered to be derived from deep carbonate aquifers (Drake and Harmon 1973). 


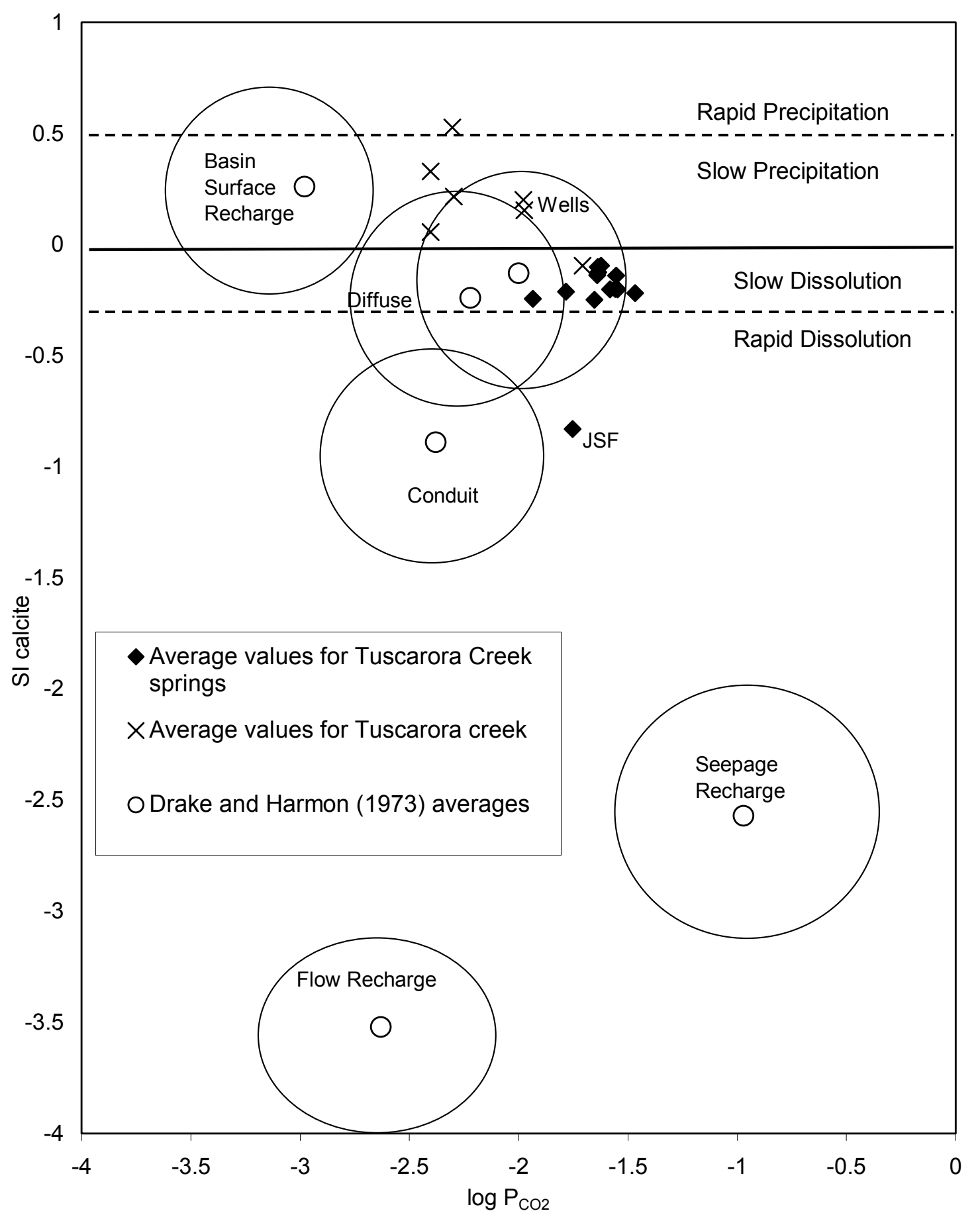

Figure 39: Comparison of average Tuscarora Creek watershed $\log \mathrm{P}_{\mathrm{CO} 2}$ and $\mathrm{SI}_{\mathrm{c}}$ values to other Appalachian sites. 
The COV of hardness has been used to differentiate springs as conduit or diffuse (Shuster and White 1971). The results of this study are not analogous perhaps because the temporal sampling frequency was greater for that investigation (Shuster and White 1971). KMR has a much higher COV of hardness, $39 \%$, than the other five springs (BRK, WAT, PHS, OLN and BEL) for which the average was about $10 \%$. KMR is located on a different formation and has a higher, more consistent flow than the other springs. In this study area, the COV of hardness may serve to differentiate between springs rather than classifying them into types.

The springs sampled for this project do not fully fit the models described. While similar in topography and geographic setting, Tuscarora Creek watershed is different from the Valley and Ridge watersheds described (Shuster and White 1971, Drake and Harmon 1974). Dolomite is abundant and widespread in those study areas, while Tuscarora Creek watershed is underlain primarily by limestone with some dolomite beds and flows across a large carbonate valley. Mountain runoff is a major contributor to flow of springs and streams (Jacobson and Langmuir 1974) while runoff from North Mountain does not appear to be significant to Tuscarora Creek. Differences in precipitation rates, snow pack and soil thickness may also account for some of these disparities. 


\section{Conclusions}

Limestone dissolution provides the strongest geochemical signature of Tuscarora Creek watershed. The majority of the watershed sampled is underlain by limestone and dolomite and the chemistry reflects that. The $\mathrm{Ca} / \mathrm{Mg}$ molar ratios exceed one for all sites, but are lower than other ratios for primarily limestone waters. This suggests the presence of dolomite in the flow paths of some of the springs, particularly PHU, PHD, BRK and BEL. This indicates that the source of the spring water likely represents geologic units other than, or in addition to, where it outcrops.

Anthropogenic influences on the watershed may be reflected in the concentrations of chloride, sodium, nitrate and sulfate. Chloride and sodium occur in an almost 1:1 ratio, suggesting that the source is $\mathrm{NaCl}$ (halite) from one or more sources. WAT has significantly higher concentrations of chloride and sodium than the other springs. This may be a cumulative effect from upgradient sources as well as from anthropogenic inputs. WAT shows an increased concentration in winter from sodium and chloride.

The springs in the upper watershed appear to be more chemically variable spatially, but there is not a straight upstream-to-downstream evolution of a karst signature on Tuscarora Creek watershed. The springs in the lower portion of the watershed have higher concentrations of calcium and magnesium.

The stream and spring samples are geochemically very similar. The majority of the samples trend along $\mathrm{CO}_{2}$ degassing reaction lines. The stream samples have lower $\mathrm{P}_{\mathrm{CO} 2}$ and higher $\mathrm{SI}_{\mathrm{C}}$, suggesting groundwater discharge and subsequent degassing. The results of the seepage run gaging of Tuscarora Creek suggest that groundwater was contributing 70 to $50 \%$ of flow to the stream at this time. 
The regional model for groundwater movement is toward the axis of the Massanutten Synclinorium, cross strike. The upper portion of Tuscarora Creek watershed developed parallel to strike. Where the stream begins to flow perpendicular to strike, the springs are larger in discharge, and have a stronger karst signature.

The springs in the upper portion have lower flow, but are more variable spatially in chemistry. The lower sites show the impacts of urbanization. The permeability of the rocks is low, and flow is enhanced by fractures and faults. 


\section{Future work}

Future work may include creating a potentiomentric map of the groundwater using wells. Sampling of wells may help to characterize the deeper water chemistry. Dye tracing would help to determine the flow paths for individual springs and to delineate groundwater basins. Storm sampling would show the response of the springs to variable hydrologic conditions. Planning a more closely spaced (temporally) sampling program would also reveal a more complete geochemical picture of the springs. Installation of data loggers would give an in-depth picture of the changing hydrologic conditions of the springs. Sampling of Tuscarora Creek above and below the spring confluence would help to capture the changing creek characteristics, especially as related to $\mathrm{CO}_{2}$ degassing. 


\section{Works cited}

APHA (2000). Alkalinity. In: Standard Methods for the Examination of Water and Wastewater. Washington, D.C., American Public Health Association. 35-39. Atkinson, T. C. (1977). Carbon dioxide in the atmosphere of the unsaturated zone: an important control of groundwater hardness in limestones. Journal of Hydrology 35: 111-123.

Brahana, J. V., J. Thrailkill, T. Freeman, W.C. Ward (1988). Carbonate Rocks. In: W. Back, J. S. Rosenshein and P. R. Seaber (Eds). Hydrogeology. Boulder, Colorado, Geological Society of America. Volume O-2. 333-352.

Davis, J. H. (2002). Statistics and Data Analysis in Geology. New York, John Wiley \& Sons. $638 \mathrm{p}$.

Desmarais, K. M. (1995). Carbonate spring response to storm events, Bear Creek Valley, Oak Ridge, TN. Masters Thesis, Duke University. 104 p.

Drake, J. J. and R. S. Harmon (1973). Hydrochemical environments of carbonate terrains. Water Resources Research 9: 949-957.

Drever, J. I. (1997). The Geochemistry of Natural Waters, Surface and Groundwater Environments, Third Edition. Upper Saddle River, NJ, Prentice Hall. 436 p.

Duigon, M. T. (2001). Karst hydrogeology of the Hagerstown Valley, Maryland. Annapolis, Maryland Department of Natural Resources. 128 p.

EPA (1983). Methods for Chemical Analysis of Water and Waste. Cincinnati, OH, Environmental Monitoring and Support Laboratory, Office of Research and Development, Environmental Protection Agency. 552 p.

EPA (1993). Methods for the determination of inorganic substances in environmental samples. Cincinnati, OH, Environmental Monitoring Systems Laboratory, Office of Research and Development, Environmental Protection Agency. 72 p.

Gordon, N. D., T. A. McMahon, B.L. Finlayson. (1992). Stream Hydrology: An Introduction for Ecologists. New York, John Wiley \& Sons. 526 p.

Gustafsson, J. P. (2005). Visual MINTEQ Version 2.32 (Accessed 7-20-2005) http://www.lwr.kth.se/english/OurSoftware/Wminteq/index.html. 
Hem, J. D. (1989). Study and Interpretation of the Chemical Characteristics of Natural Water. Washington, D.C., USGS. Water Supply Paper 2254. 263 p.

Hobba, W. A. (1976). Ground-Water Hydrology of Berkeley County, West Virginia. Morgantown, WV, WV Geological and Economic Survey. Report EGB-16. 21 p.

Howard, K. W. F. and J. Haynes (1997). Contamination of Urban Ground Water by Road De-icing Chemicals. In: N. Eyles (Ed). Environmental Geology of Urban Areas. Scarborough, Ontario, Geological Association of Canada. 145-152.

Jacobson, R. L. and D. Langmuir (1970). The chemical history of some spring waters in carbonate rocks. Ground Water 8: 5-9.

Jacobson, R. L. and D. Langmuir (1974). Controls on the quality variations of some carbonate spring waters. Journal of Hydrology 23: 247-265.

Jones, W. K. (1991). The carbonate aquifer of the Northern Shenandoah Valley of Virginia and West Virginia. In: E. H. Kastning and K. M. Kastning (Eds.) Appalachian Karst. Proceedings of the Appalachian Karst Symposium. Radford, VA: 217-222.

Jones, W. K. (1997). Karst Hydrology Atlas of West Virginia. Charles Town, WV, Karst Waters Institute. $111 \mathrm{p}$.

Langmuir, D. (1997). Aqueous Environmental Geochemistry. Upper Saddle River, NJ, Prentice Hall. 600 p.

Mahler, B. J. (1991). A geomorphic, hydrologic, and geochemical study of Hamilton Creek watershed, Travis County, Texas. Masters Thesis, University of Texas at Austin. 188 p.

Martin, J. B. and S. L. Gordon (2000). Surface and groundwater mixing, flow paths, and temporal variations in chemical compositions of karst springs. In: I. D. Sasowsky and C. M. Wicks (Eds), Groundwater flow and contaminant transport in carbonate aquifers. Rotterdam, Netherlands, A.A. Balkema. 65-92.

McColloch, J. S. (1986). Springs of West Virginia. West Virginia Geological and Economic Survey. 493 p.

McCoy, K. J., M. H. Podwysocki, E.A. Crider, D.J. Weary (2005). Fracture Trace Map and Single-well Aquifer Test Results in a Carbonate Aquifer in Berkeley County, West Virginia, USGS. OFR 05-1040. 
Moore, D. S. (2000). The Basic Practice of Statistics. New York, W.H. Freeman. 619 p. NWS (2005). History for Martinsburg, West Virginia. (Accessed 4-20-2005) http://nws.noaa.gov.

O' Driscoll, M. A., D. R. DeWalle, K.J. McGuire, W.J. Gburek (2005). Seasonal O-18 variations and groundwater recharge for three landscape types in central Pennsylvania, USA. Journal of Hydrology (303): 108-124.

Page, R. C. (1963). Geology of the Martinsburg Quadrangle, West Virginia. Masters Thesis, West Virginia University. $40 \mathrm{p}$.

Quinlan, J. F. (1989). Ground-Water Monitoring in Karst Terranes: Recommended Protocols and Implicit Assumptions. Las Vegas, Nevada, U.S. Environmental Protection Agency. 79 p.

Salg, R. H. (1997). Hydrochemical response of an urban watershed to variations in discharge. Masters Thesis, Georgia State University. 89 p.

Scanlon, B. R. and J. Thrailkill (1987). Chemical similarities among physically distinct spring types in a karst terrain. Journal of Hydrology 89: 259-279.

Schultz, R. A., W. A. Hobba, M.D. Kozar (1995). Geohydrology, Ground-water Availability, and Ground-Water Quality of Berkeley County, West Virginia, with Emphasis on the Carbonate-Rock Area. Charleston, West Virginia, USGS. WRIR 93-4073. $88 \mathrm{p}$.

Shuster, E. T. and W. B. White (1971). Seasonal fluctuations in the chemistry of limestone springs: a possible means for characterizing carbonate aquifers. Journal of Hydrology 14: 93-128.

Smart, P. L. and H. O. Hobbs (1986). Characterisation of Carbonate Aquifers: A Conceptual Base. Second Conference on Environmental Problems in Karst Terranes and Their Solutions. Bowling Green, Kentucky, National Water Well Association. 153-166.

Thomas, J. F. J. and J. J. Lynch (1960). Determination of Carbonate Alkalinity in Natural Waters. Journal of American Water Works Association 52(2): 259-268.

U.S. Census Bureau (2005). West Virginia Quick Facts. (Accessed 8-10-2005). http://quickfacts.census.gov/qfd/states/54/54003.html. 
USGS (2005). Ground-water site inventory for U.S. grouped by county. (Accessed 8-112005). http://waterdata.usgs.gov/nwis/.

White, W. B. (1969). Conceptual models for carbonate aquifers. Ground Water 7(3): 1521.

White, W. B. (1988). Geomorphology and Hydrology of Karst Terrains. New York, Oxford University Press. 464 p.

White, W. B. (1993). Analysis of Karst Aquifers. Regional Ground-Water Quality. W. M. Alley. New York, Van Nostrand Reinhold: 471-489.

White, W. B. (1997). Thermodynamic equilibrium, kinetics, activation barriers, and reaction mechanisms for chemical reactions in Karst Terrains. Environmental Geology 30: 46-58.

White, W. B. (1999). Conceptual Models for Karstic Aquifers. In: A. N. Palmer, M. V. Palmer and I. D. Sasowsky (Eds), Karst Modeling. Charlottesville, Virginia, Karst Waters Institute: 11-16.

White, W. B. (2002). Karst hydrology: recent developments and open questions. Engineering Geology 65: 85-105.

Worthington, S. R. H., D. C. Ford, G.J. Davies (2000). Matrix, fracture and channel components of storage and flow in a Paleozoic limestone aquifer. In: I. D. Sasowsky and C. M. Wicks (Eds), Groundwater flow and contaminant transport in carbonate aquifers. Rotterdam, Netherlands, A.A. Balkema: 113-128.

Zewe, B. T. and H. W. Rauch (1991). Influence of hydrogeologic setting and lineaments on water-well yield in the Great Valley karst terrane of eastern West Virginia. Appalachian Karst. In: E. H. Kastning and K. M. Kastning (Eds), Proceedings of the Appalachian Karst Symposium. Radford, VA: 223-230. 
Appendix A: Chemical data 
Table A-1: Field screening data.

\begin{tabular}{|c|c|c|c|c|c|c|}
\hline Sample Code & Date & Time & $\mathrm{pH}$ & $\begin{array}{c}\text { SPC } \\
(\mu \mathrm{S} / \mathrm{cm})\end{array}$ & $\begin{array}{c}\text { Temperature } \\
\text { (C) }\end{array}$ & $\begin{array}{c}\text { Alkalinity } \\
\left.(\mathrm{mg} / \mathrm{L} \mathrm{HCO})_{3}\right)\end{array}$ \\
\hline BEL-SP01A & $11 / 24 / 03$ & 1530 & 6.87 & 569 & 12.4 & 309 \\
\hline BEL-SP02A & $2 / 21 / 04$ & 1500 & 7.23 & 567 & 12.4 & 314 \\
\hline BEL-SP03A & 4/17/04 & 1230 & 7.08 & 687 & 12.5 & 363 \\
\hline BEL-SP04A & $6 / 4 / 04$ & 1235 & 7.04 & 575 & 12.5 & 308 \\
\hline BEL-SP05A & $7 / 21 / 04$ & 1530 & 7.89 & NM & 12.5 & 306 \\
\hline BEL-SP06A & $9 / 18 / 04$ & 1015 & 7.20 & 523 & 12.4 & 321 \\
\hline BEL-SP07A & $11 / 19 / 04$ & 1430 & 6.94 & 561 & 12.5 & 302 \\
\hline BEL-SP08A & 1/6/05 & 1315 & 7.13 & 558 & 12.5 & 317 \\
\hline BRK-SP01A & $11 / 24 / 03$ & 1445 & 7.08 & 497 & 12.9 & 240 \\
\hline BRK-SP01A & $11 / 24 / 03$ & 1445 & 7.08 & 497 & 12.9 & 240 \\
\hline BRK-SP02A & $2 / 21 / 04$ & 1430 & 7.27 & 387 & 11.8 & 221 \\
\hline BRK-SP03A & 4/17/04 & 1120 & 7.15 & 595 & 12.3 & 238 \\
\hline BRK-SP04A & $6 / 4 / 04$ & 1350 & 7.11 & 519 & 12.5 & 236 \\
\hline BRK-SP05A & $7 / 21 / 04$ & 1600 & 7.81 & NM & 12.8 & 223 \\
\hline BRK-SP06A & $9 / 18 / 04$ & 920 & 7.11 & 461 & 13.7 & 236 \\
\hline BRK-SP07A & $11 / 19 / 04$ & 1325 & 7.08 & 482 & 13.0 & 241 \\
\hline BRK-SP08A & $1 / 6 / 05$ & 1240 & 7.27 & 464 & 12.7 & 233 \\
\hline DBR-SP05A & $7 / 21 / 04$ & 1645 & 7.60 & NM & 13.5 & 306 \\
\hline DBR-SP06A & $9 / 18 / 04$ & 830 & 6.95 & 554 & 15.2 & 292 \\
\hline DBR-SP07A & $11 / 19 / 04$ & 1240 & 6.88 & 485 & 13.8 & 256 \\
\hline DBR-SP08A & $1 / 6 / 05$ & 1225 & 7.05 & 407 & 12.3 & 207 \\
\hline DOD-SP06A & $9 / 18 / 04$ & 940 & 7.12 & 510 & 12.3 & 307 \\
\hline DOD-SP07A & $11 / 19 / 04$ & 1400 & 6.96 & 549 & 12.4 & 304 \\
\hline DOD-SP08A & 1/6/05 & 1300 & 7.08 & 544 & 12.3 & 314 \\
\hline JSF-SP06A & 9/17/04 & 1540 & 6.85 & 441 & 12.3 & 266 \\
\hline JSF-SP07A & $11 / 19 / 04$ & 1130 & 6.82 & 224 & 11.6 & 126 \\
\hline JSF-SP08A & $1 / 6 / 05$ & 1040 & 7.04 & 242 & 10.3 & 151 \\
\hline KMR-SP01A & $11 / 23 / 03$ & 1130 & 6.81 & 664 & 13.1 & 335 \\
\hline KMR-SP02A & $2 / 21 / 04$ & 815 & 6.76 & 707 & 11.3 & 354 \\
\hline KMR-SP03A & $4 / 16 / 04$ & 1535 & 7.21 & 817 & 12.5 & 300 \\
\hline KMR-SP04A & $6 / 3 / 04$ & 1135 & 6.95 & 676 & 13.0 & 416 \\
\hline KMR-SP04A & $6 / 3 / 04$ & 1125 & 6.95 & 676 & 13.0 & 416 \\
\hline KMR-SP04A & $6 / 3 / 04$ & 1140 & 6.95 & 676 & 13.0 & 416 \\
\hline KMR-SP05A & $7 / 20 / 04$ & 1030 & 7.11 & NM & 12.4 & 480 \\
\hline KMR-SP06A & $9 / 18 / 04$ & 900 & 6.91 & 941 & 13.1 & 424 \\
\hline KMR-SP07A & $11 / 19 / 04$ & 1635 & 6.86 & 658 & 12.6 & 362 \\
\hline KMR-SP08A & $1 / 6 / 05$ & 1500 & 6.94 & 631 & 12.5 & 365 \\
\hline NWM-SP05A & $7 / 21 / 04$ & 1000 & 7.73 & NM & 13.9 & 341 \\
\hline NWM-SP06A & $9 / 17 / 04$ & 1300 & 7.10 & 525 & 15.0 & 335 \\
\hline NWM-SP07A & $11 / 19 / 04$ & 940 & 7.14 & 439 & 13.1 & 295 \\
\hline NWM-SP07A & $11 / 19 / 04$ & 940 & 7.14 & 439 & 13.1 & 295 \\
\hline NWM-SP08A & $1 / 6 / 05$ & 915 & 6.64 & 443 & 11.5 & 388 \\
\hline OLN-SP01A & $11 / 24 / 03$ & 1345 & 6.93 & 667 & 12.8 & 381 \\
\hline OLN-SP02A & $2 / 21 / 04$ & 1530 & 7.11 & 607 & 11.4 & 368 \\
\hline OLN-SP03A & $4 / 17 / 04$ & 1445 & 6.84 & 749 & 11.4 & 370 \\
\hline
\end{tabular}


Table A-1, continued

\begin{tabular}{|c|c|c|c|c|c|c|}
\hline Sample Code & Date & Time & $\mathrm{pH}$ & $\begin{array}{c}\mathrm{SPC} \\
(\mu \mathrm{S} / \mathrm{cm})\end{array}$ & $\begin{array}{c}\text { Temperature } \\
\text { (C) }\end{array}$ & $\begin{array}{c}\text { Alkalinity } \\
\left(\mathrm{mg} / \mathrm{L} \mathrm{HCO}_{3}\right)\end{array}$ \\
\hline OLN-SP04A & $6 / 4 / 04$ & 1140 & 6.90 & 628 & 11.8 & 459 \\
\hline OLN-SP05A & $7 / 21 / 04$ & 1440 & 7.63 & NM & 12.4 & 323 \\
\hline OLN-SP06A & $9 / 18 / 04$ & 1055 & 7.02 & 643 & 12.9 & 396 \\
\hline OLN-SP06A & $9 / 18 / 04$ & 1055 & 7.02 & 643 & 12.9 & 396 \\
\hline OLN-SP07A & $11 / 19 / 04$ & 1525 & 6.79 & 667 & 12.9 & 394 \\
\hline OLN-SP08A & $1 / 6 / 05$ & 1420 & 6.94 & 640 & 12.5 & 446 \\
\hline PHD-SP06A & 9/17/04 & 1420 & 7.01 & 551 & 13.1 & 339 \\
\hline PHD-SP07A & $11 / 19 / 04$ & 1100 & 6.92 & 557 & 12.9 & 321 \\
\hline PHD-SP08A & $1 / 6 / 05$ & 1020 & 7.28 & 565 & 12.8 & 328 \\
\hline PHS-SP01A & $11 / 24 / 03$ & 1130 & 6.92 & 585 & 14.4 & 354 \\
\hline PHS-SP02A & $2 / 21 / 04$ & 1415 & 7.16 & 494 & 10.4 & 287 \\
\hline PHS-SP03A & $4 / 17 / 04$ & 1015 & 7.52 & 475 & 14.4 & 320 \\
\hline PHS-SP04A & $6 / 4 / 04$ & 1415 & 6.87 & 560 & 13.8 & 330 \\
\hline PHS-SP06A & 9/17/04 & 1215 & 6.99 & 561 & 17.7 & 338 \\
\hline PHS-SP07A & $11 / 19 / 04$ & 1200 & 6.65 & 584 & 14.4 & 344 \\
\hline PHS-SP08A & $1 / 6 / 05$ & 1100 & 6.76 & 531 & 12.3 & 330 \\
\hline PHU-SP06A & $9 / 17 / 04$ & 1350 & 7.01 & 565 & 13.0 & 364 \\
\hline PHU-SP07A & $11 / 19 / 04$ & 1050 & 7.02 & 559 & 12.9 & 313 \\
\hline PHU-SP08A & $1 / 6 / 05$ & 1015 & 7.06 & 548 & 12.9 & 323 \\
\hline PHU-SP08A & $1 / 6 / 05$ & 1015 & 7.06 & 548 & 12.9 & 323 \\
\hline TFS-SP07A & $11 / 20 / 04$ & 845 & 6.87 & 634 & 13.3 & 511 \\
\hline TFS-SP08A & $1 / 6 / 05$ & 1400 & 6.81 & 690 & 13.2 & 356 \\
\hline WAT-SP01A & $11 / 23 / 03$ & 1430 & 6.97 & 795 & 15.0 & 383 \\
\hline WAT-SP02A & $2 / 21 / 04$ & 920 & 6.96 & 783 & 13.9 & 365 \\
\hline WAT-SP03A & $4 / 16 / 04$ & 1030 & 6.97 & 1012 & 14.2 & 385 \\
\hline WAT-SP04A & $6 / 3 / 04$ & 1330 & 6.92 & 834 & 14.0 & 398 \\
\hline WAT-SP05A & $7 / 20 / 04$ & 1250 & 7.09 & NM & 14.0 & 398 \\
\hline WAT-SP06A & 9/18/04 & 830 & 6.86 & 994 & 14.8 & 415 \\
\hline WAT-SP07A & $11 / 19 / 04$ & 1700 & 6.81 & 580 & 14.5 & 366 \\
\hline WAT-SP08A & $1 / 6 / 05$ & 1520 & 6.97 & 531 & 14.4 & 374 \\
\hline TBE-CR03A & $4 / 17 / 04$ & 1300 & 7.65 & 459 & 14.0 & 212 \\
\hline TBE-CR04A & $6 / 4 / 04$ & 1315 & 7.66 & 519 & 15.1 & 284 \\
\hline TBE-CR06A & $9 / 18 / 04$ & 1030 & 7.57 & 256 & 17.4 & 124 \\
\hline THT-CR06A & $9 / 17 / 04$ & 1355 & 7.38 & 512 & 15.5 & 301 \\
\hline TKS-CR01A & $11 / 23 / 03$ & 1130 & 7.56 & 564 & 11.9 & NM \\
\hline TKS-CR02A & $2 / 21 / 04$ & 830 & 7.58 & 433 & 7.0 & 238 \\
\hline TKS-CR03A & $4 / 16 / 04$ & 1545 & 7.89 & 644 & 14.0 & 269 \\
\hline TKS-CR04A & $6 / 3 / 04$ & 1215 & 7.57 & 625 & 14.5 & 456 \\
\hline TKS-CR06A & $9 / 18 / 04$ & 900 & 7.46 & 659 & 17.7 & 153 \\
\hline TNM-CR06A & $9 / 17 / 04$ & 1305 & 7.10 & 473 & 16.9 & 287 \\
\hline TOL-CR03A & $4 / 17 / 04$ & 1500 & 7.60 & 539 & 15.2 & 244 \\
\hline TOL-CR04A & $6 / 4 / 04$ & 1205 & 7.50 & 570 & 14.4 & 316 \\
\hline TOL-CR06A & $9 / 18 / 04$ & 1110 & 7.65 & 288 & 17.4 & 143 \\
\hline TPH-CR03A & $4 / 17 / 04$ & 1050 & 7.69 & 442 & 11.8 & 210 \\
\hline TPH-CR04A & $6 / 4 / 04$ & 1430 & 7.84 & 513 & 15.2 & 236 \\
\hline TPH-CR06A & 9/17/04 & 1500 & 7.61 & 495 & 17.0 & 297 \\
\hline TWA-CR03A & $4 / 16 / 04$ & 1115 & 7.78 & 465 & 10.6 & 244 \\
\hline
\end{tabular}


Table A-1, continued

\begin{tabular}{ccccccc}
\hline Sample Code & Date & Time & $\mathrm{pH}$ & $\begin{array}{c}\mathrm{SPC} \\
(\mu \mathrm{S} / \mathrm{cm})\end{array}$ & $\begin{array}{c}\text { Temperature } \\
(\mathrm{C})\end{array}$ & $\begin{array}{c}\text { Alkalinity } \\
\left(\mathrm{mg} / \mathrm{L} \mathrm{HCO} \mathrm{HCO}_{3}\right)\end{array}$ \\
\hline TWA-CR04A & $6 / 3 / 04$ & 1450 & 7.68 & 659 & 15.4 & 359 \\
TWA-CR04A & $6 / 3 / 04$ & 1455 & 7.68 & 659 & 15.4 & 359 \\
\hline \multicolumn{2}{c}{ NM=Not measured } & & & & & \\
\hline
\end{tabular}


Table A-2: Laboratory Results.

\begin{tabular}{|c|c|c|c|c|c|c|c|c|c|c|}
\hline mple Code & $\begin{array}{c}\mathrm{Ca} \\
(\mathrm{mg} / \mathrm{L})\end{array}$ & $\begin{array}{c}\mathrm{Mg} \\
(\mathrm{mg} / \mathrm{L})\end{array}$ & $\begin{array}{c}\mathrm{Na} \\
(\mathrm{mg} / \mathrm{L})\end{array}$ & $\begin{array}{c}\mathrm{K} \\
(\mathrm{mg} / \mathrm{L})\end{array}$ & $\begin{array}{c}\mathrm{Fe} \\
(\mathrm{mg} / \mathrm{L})\end{array}$ & $\begin{array}{c}\mathrm{Mn} \\
(\mathrm{mg} / \mathrm{L})\end{array}$ & $\begin{array}{c}\mathrm{SiO}_{2} \\
(\mathrm{mg} / \mathrm{L})\end{array}$ & $\begin{array}{c}\mathrm{SO}_{4} \\
(\mathrm{mg} / \mathrm{L})\end{array}$ & $\begin{array}{c}\mathrm{Cl} \\
(\mathrm{mg} / \mathrm{L})\end{array}$ & $\begin{array}{c}\mathrm{NO}_{3} \\
(\mathrm{mg} / \mathrm{L})\end{array}$ \\
\hline BEL-SP01A & 86.00 & 31.80 & 3.56 & 1.98 & $\overline{B D L}$ & $\mathrm{BDL}$ & 5.52 & 18.40 & 7.30 & 6.07 \\
\hline BEL-SP02A & 86.00 & 32.30 & 3.30 & 2.10 & BDL & BDL & 5.93 & 17.40 & 6.63 & 6.76 \\
\hline BEL-SP03A & 84.70 & 29.50 & 3.68 & 2.13 & BDL & BDL & 5.39 & 16.10 & 7.41 & 5.73 \\
\hline BEL-SP04A & 75.00 & 28.25 & 3.29 & 2.22 & BDL & $\mathrm{BDL}$ & 5.07 & 22.38 & 6.31 & 5.51 \\
\hline BEL-SP05A & 84.84 & 31.70 & 4.14 & 2.31 & BDL & $\mathrm{BDL}$ & 5.21 & 23.30 & 6.89 & 5.48 \\
\hline BEL-SP06A & 80.39 & 29.07 & 4.04 & 2.33 & BDL & $\mathrm{BDL}$ & 5.11 & 15.70 & 7.80 & 5.76 \\
\hline BEL-SP07A & 70.29 & 24.55 & 3.66 & 1.79 & BDL & $\mathrm{BDL}$ & 4.43 & 20.70 & 8.09 & 5.65 \\
\hline BEL-SP08A & 67.18 & 24.38 & 2.87 & 1.75 & BDL & $\mathrm{BDL}$ & 4.51 & 20.70 & 7.15 & 5.10 \\
\hline BRK-SP01A & 61.00 & 23.00 & 4.04 & 1.71 & BDL & BDL & 4.90 & 24.20 & 9.77 & 3.12 \\
\hline BRK-SP01A & 72.00 & 26.60 & 4.89 & 1.97 & BDL & BDL & 5.43 & 24.30 & 10.10 & 3.19 \\
\hline BRK-SP02A & 60.00 & 20.70 & 5.77 & 1.79 & BDL & BDL & 4.85 & 29.70 & 13.20 & 2.98 \\
\hline BRK-SP03A & 63.10 & 21.30 & 5.23 & 2.00 & BDL & BDL & 4.73 & 29.50 & 13.20 & 3.50 \\
\hline BRK-SP04A & 75.42 & 28.42 & 6.43 & 2.57 & BDL & $\mathrm{BDL}$ & 5.97 & 39.88 & 10.60 & 2.97 \\
\hline BRK-SP05A & 70.42 & 27.18 & 5.16 & 2.21 & BDL & $\mathrm{BDL}$ & 5.21 & 4 & 8.87 & 2.75 \\
\hline BRK-SP06A & 69.47 & 25.08 & 8.74 & 2.31 & BDL & $\mathrm{BDL}$ & 5.38 & 30 & 13.80 & 2.79 \\
\hline BRK-SP07A & 62.65 & 22.79 & 4.11 & 1.92 & BDL & $\mathrm{BDL}$ & 4.83 & 40 & 8.58 & 2.88 \\
\hline BRK-SP08A & 60.77 & 21.45 & 4.25 & 1.75 & BDL & $\mathrm{BDL}$ & 4.67 & 42.70 & 9.34 & 2.42 \\
\hline DBR-SP05A & 85.43 & 23.98 & 6.95 & 2.13 & BDL & $\mathrm{BDL}$ & 4.38 & 30.20 & 9.16 & 2.72 \\
\hline DBR-SP06A & 94.61 & 20.33 & 8.53 & 9.81 & BDL & $\mathrm{BDL}$ & 5.41 & 27.60 & 14.40 & 6.85 \\
\hline DBR-SP07A & 72.33 & 17.14 & 7.69 & 2.55 & 4.48 & $\mathrm{BDL}$ & 4.46 & 25.10 & 11.60 & 1.67 \\
\hline DBR-SP08A & 62.73 & 13.82 & 6.17 & 2.33 & BDL & $\mathrm{BDL}$ & 3.97 & & 9.92 & 1.35 \\
\hline DOD-SP06A & 78.33 & 24.05 & 1.77 & 2.35 & $\mathrm{BDL}$ & $\mathrm{BDL}$ & 4.98 & 20.60 & 4.30 & 3.78 \\
\hline DOD-SP07A & 78.25 & 22.72 & 1.69 & 1.96 & BDL & $\mathrm{BDL}$ & 4.98 & 26 & BDL & 3.91 \\
\hline DOD-SP08A & 68.72 & 20.56 & 1.21 & 1.64 & BDL & $\mathrm{BDL}$ & 4.60 & 26.40 & 3.78 & 3.21 \\
\hline JSF-SP06A & 69.52 & 18.26 & 14.23 & 2.32 & BDL & $\mathrm{BDL}$ & 5.89 & 21.20 & 24.70 & 0.79 \\
\hline JSF-SP07A & 36.44 & 8.80 & 5.90 & 1.49 & BDL & BDL & 4.56 & 16.70 & 7.93 & 0.41 \\
\hline JSF-SP08A & 39.44 & 9.51 & 4.51 & 1.40 & BDL & $\mathrm{BDL}$ & 4.40 & 16.30 & BDL & 0.58 \\
\hline KMR-SP01A & 86.00 & 19.10 & 5.77 & 2.18 & BDL & $\mathrm{BDL}$ & 4.72 & 19.20 & 16.40 & 5.78 \\
\hline KMR-SP02A & 112.00 & 23.40 & 8.86 & 2.92 & BDL & $\mathrm{BDL}$ & 5.65 & 18.30 & 18.60 & 19.50 \\
\hline KMR-SP03A & 98.20 & 19.90 & 7.72 & 2.64 & BDL & $\mathrm{BDL}$ & 4.89 & 18.80 & 18.60 & BDL \\
\hline KMR-SP04A & 107.13 & 23.71 & 9.00 & 3.21 & BDL & $\mathrm{BDL}$ & 5.62 & 23.10 & 15.50 & 4.39 \\
\hline KMR-SP04A & 115.01 & 25.40 & 9.55 & 3.36 & BDL & $\mathrm{BDL}$ & 5.98 & 22.43 & 15.50 & 4.77 \\
\hline KMR-SP04A & 102.34 & 22.85 & 8.53 & 3.08 & $\mathrm{BDL}$ & BDL & 5.39 & 21.97 & 15.70 & 4.57 \\
\hline KMR-SP05A & 107.46 & 24.56 & 10.74 & 2.93 & BDL & $\mathrm{BDL}$ & 5.55 & 24.40 & 14.90 & 5.59 \\
\hline KMR-SP06A & 111.50 & 23.56 & 9.28 & 3.15 & BDL & $\mathrm{BDL}$ & 5.65 & 18.30 & 18.00 & 4.00 \\
\hline KMR-SP07A & 99.81 & 19.97 & 7.67 & 2.72 & BDL & BDL & 5.01 & 23.10 & BDL & 4.54 \\
\hline KMR-SP08A & 96.25 & 19.26 & 5.93 & 2.46 & BDL & $\mathrm{BDL}$ & 4.93 & 22.50 & 14.60 & 3.92 \\
\hline NWM-SP05A & 98.30 & 16.47 & 6.94 & 2.00 & BDL & $\mathrm{BDL}$ & 4.61 & 21.60 & 7.05 & 1.52 \\
\hline NWM-SP06A & 85.13 & 14.41 & 4.67 & 1.93 & $\mathrm{BDL}$ & $\mathrm{BDL}$ & 4.27 & 19.20 & 8.51 & 1.61 \\
\hline NWM-SP07A & 76.41 & 12.38 & 4.66 & 1.59 & BDL & BDL & 3.89 & 20.20 & 6.24 & 0.94 \\
\hline NWM-SP07A & 76.84 & 12.56 & 4.43 & 1.58 & $\mathrm{BDL}$ & BDL & 3.82 & 20.10 & 6.21 & 0.93 \\
\hline NWM-SP08A & 75.26 & 11.36 & 3.47 & 1.49 & BDL & BDL & 3.93 & 20.10 & 5.48 & 0.04 \\
\hline
\end{tabular}


Table A-2, continued

\begin{tabular}{|c|c|c|c|c|c|c|c|c|c|c|}
\hline aple Code & $\begin{array}{c}\mathrm{Ca} \\
(\mathrm{mg} / \mathrm{L})\end{array}$ & $\begin{array}{c}\mathrm{Mg} \\
(\mathrm{mg} / \mathrm{L})\end{array}$ & $\begin{array}{c}\mathrm{Na} \\
(\mathrm{mg} / \mathrm{L})\end{array}$ & $\begin{array}{c}\mathrm{K} \\
(\mathrm{mg} / \mathrm{L})\end{array}$ & $\begin{array}{c}\mathrm{Fe} \\
(\mathrm{mg} / \mathrm{L})\end{array}$ & $\begin{array}{c}\mathrm{Mn} \\
(\mathrm{mg} / \mathrm{L})\end{array}$ & $\begin{array}{c}\mathrm{SiO}_{2} \\
(\mathrm{mg} / \mathrm{L})\end{array}$ & $\begin{array}{c}\mathrm{SO}_{4} \\
(\mathrm{mg} / \mathrm{L})\end{array}$ & $\begin{array}{c}\mathrm{Cl} \\
(\mathrm{mg} / \mathrm{L})\end{array}$ & $\begin{array}{c}\mathrm{NO}_{3} \\
(\mathrm{mg} / \mathrm{L})\end{array}$ \\
\hline OLN-SP01A & 96.00 & 24.50 & 3.47 & 2.47 & $\overline{B D L}$ & $\overline{B D L}$ & 4.95 & 18.50 & 9.19 & 3.57 \\
\hline OLN-SP02A & 83.00 & 21.40 & 2.65 & 3.12 & BDL & BDL & 4.75 & 16.50 & 7.18 & 4.47 \\
\hline OLN-SP03A & 81.30 & 22.90 & 2.68 & 2.87 & BDL & $\mathrm{BDL}$ & 4.88 & 14.40 & 7.17 & 3.16 \\
\hline OLN-SP04A & 94.11 & 25.29 & 3.28 & 2.91 & BDL & $\mathrm{BDL}$ & 5.20 & 21.31 & 6.31 & 2.95 \\
\hline OLN-SP05A & 115.22 & 30.60 & 5.19 & 2.99 & BDL & BDL & 6.03 & 22.00 & 8.96 & 3.95 \\
\hline OLN-SP06A & 100.63 & 25.21 & 6.06 & 4.09 & BDL & $\mathrm{BDL}$ & 5.41 & 18.40 & 13.20 & 5.73 \\
\hline OLN-SP06A & 110.93 & 27.47 & 6.57 & 4.48 & BDL & $\mathrm{BDL}$ & 5.77 & 18.50 & 13.40 & 3.73 \\
\hline OLN-SP07A & 97.07 & 23.23 & 4.67 & 2.68 & BDL & $\mathrm{BDL}$ & 4.92 & $\mathrm{BDL}$ & BDL & BDL \\
\hline OLN-SP08A & 90.11 & 22.50 & 3.16 & 2.32 & BDL & $\mathrm{BDL}$ & 4.89 & 19.40 & 7.98 & 2.75 \\
\hline PHD-SP06A & 90.15 & 32.11 & 3.10 & 2.29 & BDL & $\mathrm{BDL}$ & 5.84 & 30.80 & 5.40 & 5.33 \\
\hline PHD-SP07A & 85.62 & 29.46 & 2.91 & 1.98 & BDL & $\mathrm{BDL}$ & 5.51 & 37.20 & $\mathrm{BDL}$ & 5.29 \\
\hline PHD-SP08A & 86.95 & 30.27 & 2.54 & 2.33 & BDL & $\mathrm{BDL}$ & 5.52 & 36.50 & 5.10 & 4.84 \\
\hline PHS-SP01A & 85.00 & 20.70 & 2.37 & 1.65 & $\mathrm{BDL}$ & $\mathrm{BDL}$ & 4.31 & & 5.42 & 2.34 \\
\hline PHS-SP02A & 86.00 & 20.30 & 2.46 & 2.21 & BDL & $\mathrm{BDL}$ & 44 & 00 & 3 & 1.99 \\
\hline PHS-SP03A & 83.20 & 18.60 & 2.72 & 1.91 & BDL & $\mathrm{BDL}$ & 4.01 & 10 & .08 & 2.15 \\
\hline PHS-SP04A & 85.81 & 22.15 & 3.04 & 1.86 & BDL & $\mathrm{BDL}$ & 4.23 & 21.44 & 65 & 2.42 \\
\hline PHS-SP06A & 93.02 & 23.78 & 3.15 & 2.45 & $\mathrm{BDL}$ & $\mathrm{BDL}$ & 4.63 & 18.10 & 6.61 & 2.18 \\
\hline PHS-SP07A & 91.73 & 21.88 & 3.39 & 1.79 & BDL & $\mathrm{BDL}$ & 4.33 & 21.30 & 6.82 & 2.02 \\
\hline PHS-SP08A & 92.38 & 22.16 & 2.86 & 1.88 & BDL & $\mathrm{BDL}$ & 4.30 & $\mathrm{BDL}$ & $\mathrm{BDL}$ & $\mathrm{BDL}$ \\
\hline PHU-SP06A & 75.22 & 27.08 & 2.60 & 2.05 & BDL & $\mathrm{BDL}$ & 5.01 & 30.60 & 5.43 & 5.23 \\
\hline PHU-SP07A & 99.21 & 33.16 & 3.56 & 2.23 & BDL & $\mathrm{BDL}$ & 6.07 & 37.70 & 5.66 & 5.32 \\
\hline PHU-SP08A & 82.18 & 28.80 & 2.43 & 1.74 & $\mathrm{BDL}$ & $\mathrm{BDL}$ & & 36.60 & 4.94 & 4.68 \\
\hline PHU-SP08A & 74.18 & 26.10 & 2.24 & 1.66 & BDL & $\mathrm{BDL}$ & & 37.10 & 4.96 & 4.70 \\
\hline TFS-SP07A & 96.64 & 26.28 & 11.60 & 2.43 & BDL & $\mathrm{BDL}$ & 5.11 & BDL & $\mathrm{BDL}$ & BDL \\
\hline TFS-SP08A & 91.78 & 25.73 & 9.13 & 2.46 & BDL & $\mathrm{BDL}$ & 5.06 & 25.30 & 22.70 & 5.23 \\
\hline WAT-SP01A & 110.00 & 22.70 & 22.80 & 3.04 & BDL & $\mathrm{BDL}$ & 4.06 & 25.20 & 44.50 & 3.96 \\
\hline WAT-SP02A & 143.00 & 29.60 & 31.70 & 4.00 & BDL & $\mathrm{BDL}$ & 5.29 & 34.30 & 56.60 & 4.41 \\
\hline WAT-SP03A & 110.90 & 21.20 & 23.20 & 3.29 & BDL & $\mathrm{BDL}$ & 3.81 & 33.40 & 54.70 & 4.52 \\
\hline WAT-SP04A & 118.61 & 24.75 & 25.99 & 3.80 & BDL & $\mathrm{BDL}$ & 4.33 & 45.58 & 41.40 & 18.60 \\
\hline WAT-SP05A & 115.13 & 25.85 & 26.78 & 3.61 & 0.18 & 0.17 & 4.47 & 44.50 & 46.10 & 3.70 \\
\hline WAT-SP06A & 105.49 & 21.69 & 21.74 & 3.74 & BDL & $\mathrm{BDL}$ & 4.09 & 33.80 & 42.30 & 3.71 \\
\hline WAT-SP07A & 110.79 & 22.07 & 21.86 & 3.39 & BDL & BDL & 4.03 & 44.30 & 46.50 & 3.30 \\
\hline WAT-SP08A & 114.77 & 23.26 & 21.33 & 3.19 & BDL & $\mathrm{BDL}$ & 4.27 & 43.60 & 44.20 & 3.16 \\
\hline TBE-CR03A & 46.50 & 11.80 & 4.39 & 1.55 & $\mathrm{BDL}$ & $\mathrm{BDL}$ & 3.05 & 17.00 & 7.30 & 1.70 \\
\hline TBE-CR04A & 82.69 & 22.50 & 4.48 & 2.48 & BDL & $\mathrm{BDL}$ & 4.86 & 16.27 & 5.63 & 7.41 \\
\hline TBE-CR06A & 38.43 & 8.97 & 3.66 & 4.90 & 0.17 & $\mathrm{BDL}$ & $\mathrm{BDL}$ & 19.20 & 6.27 & 1.60 \\
\hline THT-CR06A & 91.99 & 18.80 & 4.30 & 2.46 & BDL & $\mathrm{BDL}$ & 4.64 & 19.10 & 7.99 & 2.28 \\
\hline TKS-CR01A & 88.00 & 21.60 & 6.81 & 2.48 & 0.19 & 0.18 & 5.12 & 19.20 & 12.90 & 2.80 \\
\hline TKS-CR02A & 62.00 & 13.90 & 5.87 & 2.15 & BDL & $\mathrm{BDL}$ & & 17.20 & 13.00 & 2.31 \\
\hline TKS-CR03A & 71.50 & 16.60 & 15.40 & 2.42 & 0.22 & 0.22 & 4.21 & 18.10 & 14.10 & 3.28 \\
\hline TKS-CR04A & 93.75 & 23.36 & 8.58 & 2.77 & BDL & $\mathrm{BDL}$ & 5.09 & 22.90 & 13.90 & 2.65 \\
\hline TKS-CR06A & 46.12 & 10.62 & 4.96 & 5.74 & 0.23 & $\mathrm{BDL}$ & BDL & 18.80 & 8.62 & 1.70 \\
\hline TNM-CR06A & 85.87 & 13.62 & 4.15 & 2.87 & BDL & $\mathrm{BDL}$ & 4.39 & 17.20 & 7.81 & 1.94 \\
\hline TOL-CR03A & 76.60 & 19.90 & 5.86 & 2.35 & BDL & $\mathrm{BDL}$ & 4.42 & 17.50 & 9.34 & 2.31 \\
\hline TOL-CR04A & 87.23 & 24.20 & 5.64 & 2.63 & BDL & $\mathrm{BDL}$ & 4.92 & 19.26 & 8.42 & 2.70 \\
\hline TOL-CR06A & 43.02 & 10.51 & 4.13 & 5.33 & 0.23 & $\mathrm{BDL}$ & BDL & 19.10 & 6.97 & 1.79 \\
\hline TPH-CR03A & 53.10 & 11.60 & 3.70 & 1.65 & $\mathrm{BDL}$ & $\mathrm{BDL}$ & 3.35 & 15.10 & 7.04 & 1.69 \\
\hline
\end{tabular}


Table A-2, continued

\begin{tabular}{ccccccccccc}
\hline Sample Code & $\begin{array}{c}\mathrm{Ca} \\
(\mathrm{mg} / \mathrm{L})\end{array}$ & $\begin{array}{c}\mathrm{Mg} \\
(\mathrm{mg} / \mathrm{L})\end{array}$ & $\begin{array}{c}\mathrm{Na} \\
(\mathrm{mg} / \mathrm{L})\end{array}$ & $\begin{array}{c}\mathrm{K} \\
(\mathrm{mg} / \mathrm{L})\end{array}$ & $\begin{array}{c}\mathrm{Fe} \\
(\mathrm{mg} / \mathrm{L})\end{array}$ & $\begin{array}{c}\mathrm{Mn} \\
(\mathrm{mg} / \mathrm{L})\end{array}$ & $\begin{array}{c}\mathrm{SiO}_{2} \\
(\mathrm{mg} / \mathrm{L})\end{array}$ & $\begin{array}{c}\mathrm{SO}_{4} \\
(\mathrm{mg} / \mathrm{L})\end{array}$ & $\begin{array}{c}\mathrm{Cl} \\
(\mathrm{mg} / \mathrm{L})\end{array}$ & $\begin{array}{c}\mathrm{NO}_{3} \\
(\mathrm{mg} / \mathrm{L})\end{array}$ \\
\hline TPH-CR04A & 80.84 & 19.49 & 4.80 & 2.56 & $\mathrm{BDL}$ & $\mathrm{BDL}$ & 4.83 & 16.58 & 7.01 & 2.44 \\
TPH-CR06A & 79.54 & 20.38 & 4.37 & 3.11 & $\mathrm{BDL}$ & $\mathrm{BDL}$ & 4.54 & 20.50 & 8.02 & 2.31 \\
TWA-CR03A & 85.00 & 18.20 & 10.10 & 2.74 & $\mathrm{BDL}$ & $\mathrm{BDL}$ & 4.02 & 17.70 & 21.80 & 3.07 \\
TWA-CR04A & 101.65 & 23.49 & 12.81 & 3.49 & 0.13 & 0.13 & 5.23 & 27.35 & 14.00 & 16.50 \\
TWA-CR04A & 99.83 & 22.81 & 12.67 & 3.32 & $\mathrm{BDL}$ & $\mathrm{BDL}$ & 4.97 & 25.91 & 21.10 & 2.87 \\
\hline
\end{tabular}


Table A-3: Derived Parameters.

\begin{tabular}{|c|c|c|c|c|c|}
\hline Sample Code & $\begin{array}{l}\mathrm{P}_{\mathrm{cO} 2} \\
(\mathrm{~atm})\end{array}$ & $S I_{\text {calcite }}$ & $\begin{array}{l}\text { SI (disord. } \\
\text { Dolomite) }\end{array}$ & $\begin{array}{c}\text { SI (ordered } \\
\text { Dolomite) }\end{array}$ & $\begin{array}{c}\text { Charge } \\
\text { balance } \%\end{array}$ \\
\hline BEL-SP01A & 0.0337 & -0.37 & -1.61 & -1.01 & 14.5 \\
\hline BEL-SP02A & 0.0149 & -0.02 & -0.90 & -0.29 & 10.5 \\
\hline BEL-SP03A & 0.0243 & -0.11 & -1.11 & -0.51 & 2.9 \\
\hline BEL-SP04A & 0.0228 & -0.26 & -1.39 & -0.78 & 4.2 \\
\hline BEL-SP05A & 0.0313 & 0.62 & 0.38 & 0.98 & 10.5 \\
\hline BEL-SP06A & 0.0164 & -0.06 & -1.15 & -0.55 & 0.9 \\
\hline BEL-SP07A & 0.0283 & -0.39 & -1.68 & -1.08 & 0.3 \\
\hline BEL-SP08A & 0.0192 & -0.20 & -1.28 & -0.68 & 3.5 \\
\hline BRK-SP01A & 0.0165 & -0.38 & -1.62 & -1.01 & 10.0 \\
\hline BRK-SP01A & 0.0164 & -0.32 & -1.51 & -0.90 & 17.6 \\
\hline BRK-SP02A & 0.0097 & -0.26 & -1.44 & -0.84 & 3.8 \\
\hline BRK-SP03A & 0.0138 & -0.33 & -1.57 & -0.96 & 3.0 \\
\hline BRK-SP04A & 0.0149 & -0.31 & -1.47 & -0.87 & 12.8 \\
\hline BRK-SP05A & 0.0028 & 0.34 & -0.16 & 0.44 & 11.7 \\
\hline BRK-SP06A & 0.0152 & -0.32 & -1.48 & -0.89 & 9.8 \\
\hline BRK-SP07A & 0.0165 & -0.39 & -1.64 & -1.04 & 1.5 \\
\hline BRK-SP08A & 0.0103 & -0.23 & -1.34 & -0.74 & 0.2 \\
\hline DBR-SP05A & 0.0063 & 0.36 & -0.25 & 0.34 & 5.4 \\
\hline DBR-SP06A & 0.0274 & -0.24 & -1.53 & -0.94 & 9.2 \\
\hline DBR-SP07A & 0.0281 & -0.48 & -2.00 & -1.40 & 3.7 \\
\hline DBR-SP08A & 0.0152 & -0.48 & -2.05 & -1.44 & 4.9 \\
\hline DOD-SP06A & 0.0189 & -0.17 & -1.28 & -0.68 & 3.4 \\
\hline DOD-SP07A & 0.0271 & -0.33 & -1.63 & -1.03 & 2.7 \\
\hline DOD-SP08A & 0.0213 & -0.25 & -1.46 & -0.86 & 6.0 \\
\hline JSF-SP06A & 0.0307 & -0.54 & -2.10 & -1.50 & 1.3 \\
\hline JSF-SP07A & 0.0159 & -1.13 & -3.32 & -2.71 & 3.6 \\
\hline JSF-SP08A & 0.0113 & -0.82 & -2.74 & -2.12 & 2.8 \\
\hline KMR-SP01A & 0.0425 & -0.38 & -1.84 & -1.24 & 1.3 \\
\hline KMR-SP02A & 0.0487 & -0.35 & -1.84 & -1.23 & 6.7 \\
\hline KMR-SP03A & 0.0150 & 0.01 & -1.12 & -0.51 & 8.9 \\
\hline KMR-SP04A & 0.0375 & -0.06 & -1.20 & -0.60 & 3.4 \\
\hline KMR-SP04A & 0.0377 & -0.10 & -1.28 & -0.68 & 2.4 \\
\hline KMR-SP04A & 0.0038 & -0.09 & -1.25 & -0.65 & 0.2 \\
\hline KMR-SP05A & 0.0297 & 0.12 & -0.84 & -0.24 & 5.9 \\
\hline KMR-SP06A & 0.0421 & -0.10 & -1.30 & -0.70 & 0.5 \\
\hline KMR-SP07A & 0.0407 & -0.25 & -1.62 & -1.02 & 4.1 \\
\hline KMR-SP08A & 0.0339 & -0.19 & -1.52 & -0.92 & 1.7 \\
\hline NWM-SP05A & 0.0052 & 0.60 & 0.01 & 0.61 & 2.8 \\
\hline NWM-SP06A & 0.0234 & -0.07 & -1.30 & -0.70 & 4.1 \\
\hline NWM-SP07A & 0.0176 & -0.15 & -1.51 & -0.91 & 3.7 \\
\hline NWM-SP07A & 0.0176 & -0.16 & -1.50 & -0.90 & 3.4 \\
\hline NWM-SP08A & 0.0720 & -0.57 & -2.42 & -1.81 & 17.9 \\
\hline OLN-SP01A & 0.0362 & -0.18 & -1.37 & -0.77 & 3.8 \\
\hline
\end{tabular}


Table A-3, continued

\begin{tabular}{|c|c|c|c|c|c|}
\hline Sample Code & $\begin{array}{l}\mathrm{P}_{\mathrm{cO} 2} \\
\text { (atm) }\end{array}$ & $S I_{\text {calcite }}$ & $\begin{array}{l}\text { SI (disord. } \\
\text { Dolomite) }\end{array}$ & $\begin{array}{c}\text { SI (ordered } \\
\text { Dolomite) }\end{array}$ & $\begin{array}{c}\text { Charge } \\
\text { balance } \%\end{array}$ \\
\hline OLN-SP02A & 0.0287 & -0.10 & -1.24 & -0.63 & 4.6 \\
\hline OLN-SP03A & 0.0043 & -0.37 & -1.75 & -1.14 & 3.5 \\
\hline OLN-SP04A & 0.0461 & -0.17 & -1.35 & -0.75 & 8.2 \\
\hline OLN-SP05A & 0.0060 & 0.50 & -0.01 & 0.60 & 17.8 \\
\hline OLN-SP06A & 0.0305 & -0.06 & -1.15 & -0.55 & 0.9 \\
\hline OLN-SP06A & 0.0305 & -0.06 & -1.15 & -0.55 & 0.9 \\
\hline OLN-SP07A & 0.0518 & -0.30 & -1.64 & -1.04 & 4.3 \\
\hline OLN-SP08A & 0.0413 & -0.14 & -1.32 & -0.72 & 10.2 \\
\hline PHD-SP06A & 0.0273 & -0.16 & -2.20 & -1.60 & 15.0 \\
\hline PHD-SP07A & 0.0313 & -0.32 & -1.52 & -0.92 & 6.0 \\
\hline PHD-SP08A & 0.0139 & 0.06 & -0.77 & -0.17 & 5.1 \\
\hline PHS-SP01A & 0.0354 & -0.23 & -1.48 & -0.88 & 1.0 \\
\hline PHS-SP02A & 0.0158 & -0.14 & -1.39 & -0.78 & 8.5 \\
\hline PHS-SP03A & 0.0080 & 0.31 & -0.43 & 0.17 & 1.1 \\
\hline PHS-SP04A & 0.0367 & -0.33 & -1.65 & -1.05 & 2.2 \\
\hline PHS-SP06A & 0.0298 & -0.11 & -1.14 & -0.56 & 5.3 \\
\hline PHS-SP07A & 0.0639 & -0.50 & -2.01 & -1.41 & 2.1 \\
\hline PHS-SP08A & 0.0464 & -0.42 & -1.90 & -1.30 & 10.2 \\
\hline PHU-SP06A & 0.0290 & -0.22 & -1.31 & -0.71 & 5.6 \\
\hline PHU-SP07A & 0.0247 & -0.16 & -1.23 & -0.62 & 11.8 \\
\hline PHU-SP08A & 0.0286 & -0.19 & -1.26 & -0.66 & 2.8 \\
\hline PHU-SP08A & 0.0229 & -0.23 & -1.29 & -0.69 & 0.4 \\
\hline TFS-SP07A & 0.0559 & -0.11 & -1.21 & -0.61 & 5.3 \\
\hline TFS-SP08A & 0.0448 & -0.35 & -1.67 & -1.07 & 0.5 \\
\hline WAT-SP01A & 0.0338 & -0.05 & -1.18 & -0.59 & 5.6 \\
\hline WAT-SP02A & 0.0323 & -0.02 & -1.13 & -0.54 & 14.5 \\
\hline WAT-SP03A & 0.0368 & -0.08 & -1.27 & -0.67 & 1.1 \\
\hline WAT-SP04A & 0.0388 & -0.10 & -1.28 & -0.68 & 1.4 \\
\hline WAT-SP05A & 0.0262 & 0.06 & -0.93 & -0.33 & 1.9 \\
\hline WAT-SP06A & 0.0472 & -0.17 & -1.40 & -0.81 & 4.1 \\
\hline WAT-SP07A & 0.0465 & -0.25 & -1.60 & -1.01 & 0.6 \\
\hline WAT-SP08A & 0.0327 & -0.07 & -1.24 & -0.64 & 1.9 \\
\hline TBE-CR03A & 0.0040 & 0.04 & -0.91 & -0.31 & 6.9 \\
\hline TBE-CR04A & 0.0052 & 0.41 & -0.14 & 0.45 & 8.7 \\
\hline TBE-CR06A & 0.0030 & -0.28 & -1.54 & -0.96 & 11.5 \\
\hline THT-CR06A & 0.0105 & 0.20 & -0.66 & -0.07 & 6.9 \\
\hline TKS-CR01A & NM & NM & NM & NM & NM \\
\hline TKS-CR02A & 0.0048 & 0.01 & -1.17 & -0.54 & 1.4 \\
\hline TKS-CR03A & 0.0028 & 0.54 & 0.04 & 0.63 & 4.6 \\
\hline TKS-CR04A & 0.0101 & 0.54 & 0.07 & 0.67 & 9.0 \\
\hline TKS-CR06A & 0.0047 & -0.22 & -1.42 & -0.84 & 5.6 \\
\hline TNM-CR06A & 0.0196 & -0.10 & -1.34 & -0.76 & 3.3 \\
\hline TOL-CR03A & 0.0051 & 0.26 & -0.45 & 0.14 & 11.4 \\
\hline TOL-CR04A & 0.0082 & 0.30 & -0.36 & 0.23 & 6.6 \\
\hline TOL-CR06A & 0.0284 & -0.09 & -1.14 & -0.56 & 5.9 \\
\hline TPH-CR03A & 0.0035 & 0.10 & -0.91 & -0.30 & 2.0 \\
\hline TPH-CR04A & 0.0028 & 0.50 & 0.01 & 0.60 & 14.6 \\
\hline
\end{tabular}


Table A-3, continued

\begin{tabular}{cccccc}
\hline Sample Code & $\begin{array}{c}\mathrm{P}_{\mathrm{CO} 2} \\
(\mathrm{~atm})\end{array}$ & SI $_{\text {calcite }}$ & $\begin{array}{c}\text { SI (disord. } \\
\text { Dolomite) }\end{array}$ & $\begin{array}{c}\text { SI (ordered } \\
\text { Dolomite) }\end{array}$ & $\begin{array}{c}\text { Charge } \\
\text { balance \% }\end{array}$ \\
\hline TPH-CR06A & 0.0062 & 0.39 & -0.16 & 0.42 & 3.2 \\
TWA-CR03A & 0.0032 & 0.41 & -0.32 & 0.29 & 11.6 \\
TWA-CR04A & 0.0062 & 0.59 & 0.17 & 0.76 & 3.8 \\
TWA-CR04A & 0.0062 & 0.59 & 0.16 & 0.75 & 3.1 \\
\hline \multicolumn{7}{c}{ NM=Not measured }
\end{tabular}


Appendix B: GIS metadata 
Table B-1: Source of GIS data.

\begin{tabular}{|c|c|c|c|}
\hline Type of Data & Scale & Source & Projection \\
\hline $\begin{array}{l}\text { Spring locations } \\
\text { and Tuscarora } \\
\text { Creek gaging } \\
\text { locations }\end{array}$ & $\begin{array}{l}\text { NA- Data } \\
\text { collected } \\
\text { using } \\
\text { Garmin } \\
\text { ETREX } \\
\text { Legend GPS }\end{array}$ & Rachel Grand & NAD 83 UTM Zone $17 \mathrm{~N}$ \\
\hline Counties & $1: 24000$ & http://www.wvgis.wvu.edu/ & NAD 83 UTM Zone $17 \mathrm{~N}$ \\
\hline Geology & $1: 7500000$ & http://www.wvgis.wvu.edu/ & NAD 83 UTM Zone $17 \mathrm{~N}$ \\
\hline Towns & $1: 24000$ & http://www.wvgis.wvu.edu/ & NAD 83 UTM Zone $17 \mathrm{~N}$ \\
\hline Streams & $1: 24000$ & http://www.wvgis.wvu.edu/ & NAD 83 UTM Zone $17 \mathrm{~N}$ \\
\hline Roads & $1: 24000$ & http://www.wvgis.wvu.edu/ & NAD 83 UTM Zone $17 \mathrm{~N}$ \\
\hline $\begin{array}{l}\text { Gap Land Use Land } \\
\text { Cover (GAPLULC) }\end{array}$ & $1: 50000$ & http://www.wvgis.wvu.edu/ & NAD 83 UTM Zone $17 \mathrm{~N}$ \\
\hline $\begin{array}{c}\text { Watershed } \\
\text { Boundary Dataset } \\
(8,10,12 \text {-digit })\end{array}$ & $1: 24000$ & http://www.wvgis.wvu.edu/ & NAD 83 UTM Zone $17 \mathrm{~N}$ \\
\hline
\end{tabular}


Table B-2: UTM coordinates of Tuscarora Creek watershed springs.

\begin{tabular}{|c|c|c|c|c|}
\hline Site ID & DATUM & ZONE & Easting & Northing \\
\hline BEL & Nad_83 & $17 \mathrm{~S}$ & 755913 & 4372843 \\
\hline BRK & Nad_83 & $17 \mathrm{~S}$ & 755347 & 4373119 \\
\hline DBR & Nad_83 & $17 \mathrm{~S}$ & 755197 & 4373129 \\
\hline DOD & Nad_83 & $17 \mathrm{~S}$ & 755565 & 4373213 \\
\hline JSF & Nad_83 & $17 \mathrm{~S}$ & 754171 & 4371817 \\
\hline KMR & Nad_83 & $18 S$ & 243691 & 4373141 \\
\hline NWM & Nad_83 & $17 \mathrm{~S}$ & 753972 & 4370527 \\
\hline OLN & Nad_83 & $17 \mathrm{~S}$ & 757377 & 4372473 \\
\hline PHD & Nad_83 & $17 \mathrm{~S}$ & 754266 & 4371085 \\
\hline PHS & Nad_83 & $17 \mathrm{~S}$ & 754770 & 4372140 \\
\hline PHU & Nad_83 & $17 \mathrm{~S}$ & 754259 & 4371064 \\
\hline TFS & Nad_83 & $17 \mathrm{~S}$ & 756884 & 4372591 \\
\hline WAT & Nad_83 & $18 S$ & 245122 & 4371249 \\
\hline
\end{tabular}


Table B-3: UTM coordinates of Tuscarora Creek gaging sites, November 2004.

\begin{tabular}{|c|c|c|c|}
\hline DATUM & ZONE & Easting & Northing \\
\hline Nad_83 & $17 \mathrm{~S}$ & 755542 & 4373030 \\
\hline Nad_83 & $17 \mathrm{~S}$ & 755933 & 4372848 \\
\hline Nad_83 & $17 \mathrm{~S}$ & 755903 & 4372913 \\
\hline Nad_83 & $17 \mathrm{~S}$ & 756265 & 4372454 \\
\hline Nad_83 & $17 \mathrm{~S}$ & 756683 & 4372495 \\
\hline Nad_83 & $17 \mathrm{~S}$ & 757112 & 4372563 \\
\hline Nad_83 & $17 \mathrm{~S}$ & 757360 & 4372461 \\
\hline Nad_83 & $17 \mathrm{~S}$ & 757679 & 4372862 \\
\hline Nad_83 & $17 \mathrm{~S}$ & 242698 & 4373271 \\
\hline Nad_83 & $17 \mathrm{~S}$ & 755551 & 4373109 \\
\hline Nad_83 & $17 \mathrm{~S}$ & 755540 & 4373026 \\
\hline Nad_83 & $17 \mathrm{~S}$ & 753972 & 4370528 \\
\hline Nad_83 & $17 \mathrm{~S}$ & 753973 & 4370586 \\
\hline Nad_83 & $17 \mathrm{~S}$ & 753997 & 4370610 \\
\hline Nad_83 & $17 \mathrm{~S}$ & 754229 & 4371019 \\
\hline Nad_83 & $17 \mathrm{~S}$ & 754277 & 4371117 \\
\hline Nad_83 & $17 \mathrm{~S}$ & 754185 & 4371828 \\
\hline Nad_83 & $17 \mathrm{~S}$ & 754665 & 4371789 \\
\hline Nad_83 & $17 \mathrm{~S}$ & 754900 & 4372083 \\
\hline Nad_83 & $17 \mathrm{~S}$ & 755215 & 4373119 \\
\hline Nad_83 & $17 \mathrm{~S}$ & 755317 & 4373090 \\
\hline Nad_83 & $17 \mathrm{~S}$ & 755540 & 4373026 \\
\hline Nad_83 & $17 \mathrm{~S}$ & 755321 & 4372892 \\
\hline
\end{tabular}




\section{Appendix C: Equipment and laboratory information}


Table C-1: Field equipment information.

\begin{tabular}{|c|c|c|c|c|c|}
\hline $\begin{array}{l}\text { Physical } \\
\text { Measurements }\end{array}$ & Units & $\begin{array}{l}\text { Equipment } \\
\text { used }\end{array}$ & $\begin{array}{l}\text { Equipment } \\
\text { accuracy }\end{array}$ & Source of information & $\begin{array}{c}\text { Possible source(s) } \\
\text { of error }\end{array}$ \\
\hline $\mathrm{pH}$ & $\mathrm{pH}$ & $\begin{array}{c}\text { Hanna } \\
9025 \mathrm{C} \mathrm{pH} \\
\text { probe }\end{array}$ & $+/-0.01 \mathrm{pH}$ & $\begin{array}{c}\text { http://www.hannainst. } \\
\text { com/usa }\end{array}$ & $\begin{array}{l}\text { Calibration, probe } \\
\text { damage }\end{array}$ \\
\hline Temperature & Celsius & $\begin{array}{c}\text { Hanna } \\
9025 \mathrm{C} \\
\text { temperature } \\
\text { probe }\end{array}$ & $+/-0.04 \mathrm{C}$ & $\begin{array}{c}\text { http://www.hannainst. } \\
\text { com/usa }\end{array}$ & calibration \\
\hline SC & $\begin{array}{l}\text { microsiemens } \\
/ \mathrm{cm}\end{array}$ & $\begin{array}{c}\text { Hanna HI } \\
9033 \\
\text { conductivity } \\
\text { probe }\end{array}$ & $+/-1 \%$ & $\begin{array}{c}\text { http://www.hannainst. } \\
\text { com/usa }\end{array}$ & calibration \\
\hline \multirow{3}{*}{ Flow } & feet/second & $\begin{array}{c}\text { Swoffer } \\
\text { Model } 2100\end{array}$ & $\begin{array}{l}+/-1 \% \\
\text { when user } \\
\text { calibrated }\end{array}$ & $\begin{array}{l}\text { http://www.swoffer. } \\
\text { com }\end{array}$ & \multirow{3}{*}{$\begin{array}{c}\text { operator } \\
\text { interference }\end{array}$} \\
\hline & & Flow & & & \\
\hline & feet/second & $\begin{array}{l}\text { Meter with } \\
\text { Aquacalc } \\
500 \text { keypad }\end{array}$ & * & http://www.rickly.com & \\
\hline Alkalinity & $\begin{array}{c}\mathrm{mg} / \mathrm{L} \mathrm{CaCO}_{3} \\
\text { and } \mathrm{mg} / \mathrm{L} \\
\mathrm{HCO}_{3}^{-}\end{array}$ & $\begin{array}{l}\text { Hanna pH } \\
\text { meter (see } \\
\text { above), } \\
\text { Hach digital } \\
\text { titrator }\end{array}$ & $\begin{array}{l}+/-1 \% \text { for } \\
\text { readings } \\
\text { over } 100 \\
\text { clicks }\end{array}$ & http://www.hach.com & degassing \\
\hline \multirow{2}{*}{ Water Depth } & \multirow{2}{*}{ feet } & $\begin{array}{c}\text { Solinst } \\
\text { Water Level } \\
\text { Meter Model } \\
101\end{array}$ & $1 / 100$ foot & $\begin{array}{l}\text { http://www.solinst. } \\
\text { com }\end{array}$ & \multirow{2}{*}{$\begin{array}{l}\text { dying battery, } \\
\text { operator read error }\end{array}$} \\
\hline & & $\begin{array}{c}\text { Heron } \\
\text { Instruments } \\
100 \text { foot } \\
\text { Dipper T }\end{array}$ & $\begin{array}{l}+/-1 / 100 \\
\text { foot per } 100 \\
\text { foot }\end{array}$ & $\begin{array}{c}\mathrm{http}: / / \mathrm{www} \text {. } \\
\text { heroninstruments. } \\
\text {.com }\end{array}$ & \\
\hline
\end{tabular}

* The majority of error for flow measurements is derived from sources beyond the equipment. The geometry of the stream, interference of the operator's body with flow of the water and the general absence of smooth, laminar flow all combine to produce much higher error in the field than reported by the manufacturer. 
Table C-2: Laboratory methods information.

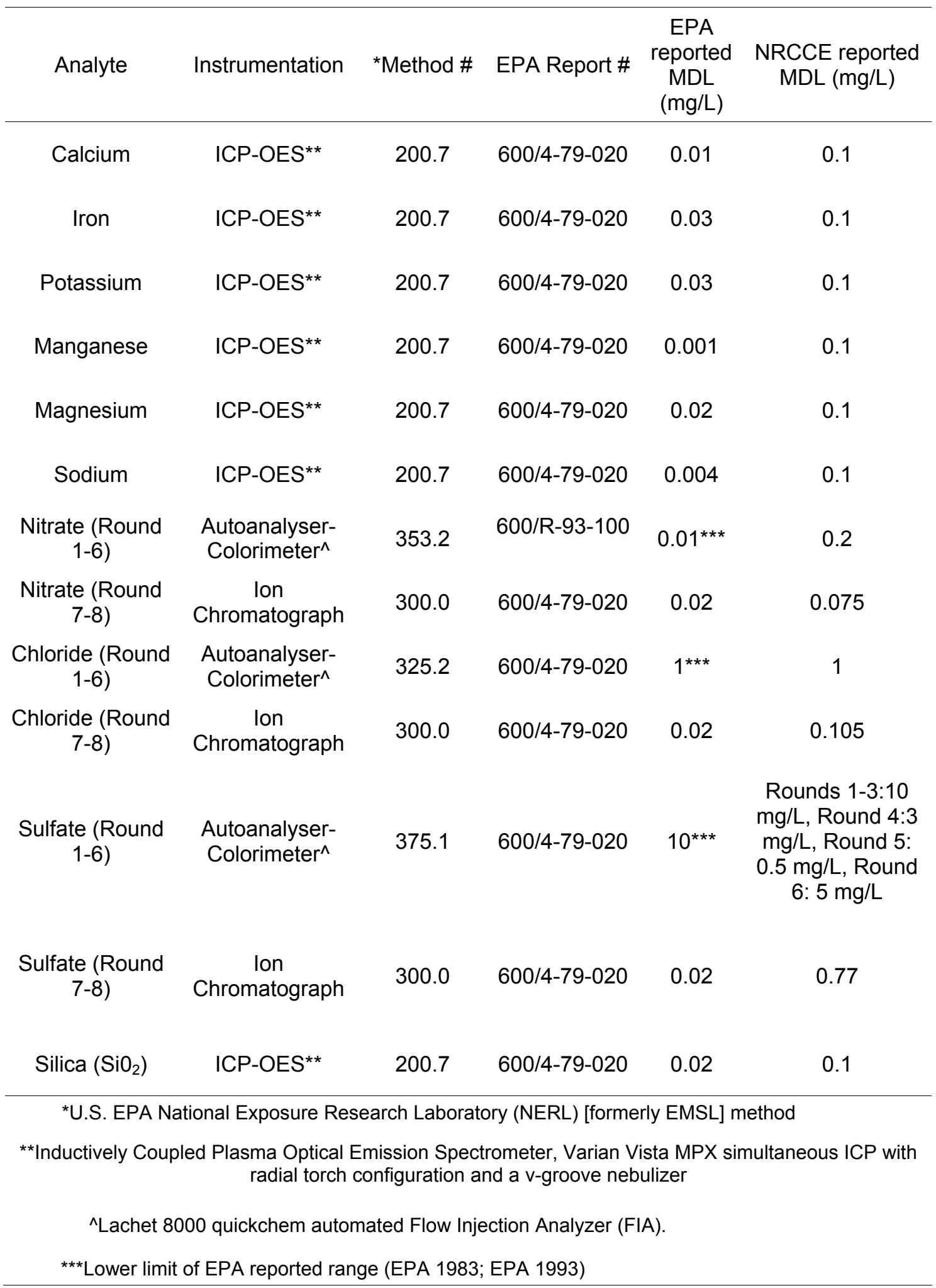

